\title{
Primates in peril: the significance of Brazil, Madagascar, Indonesia and the Democratic Republic of the Congo for global primate conservation
}

Alejandro Estrada Corresp., 1 , Paul A Garber ${ }^{2}$, Russell A Mittermeier ${ }^{3}$, Serge Wich ${ }^{4}$, Sidney Gouveia ${ }^{5}$, Ricardo Dobrovolski $^{6}$, K.A.I. Nekaris ${ }^{7}$, Vincent Nijman ${ }^{7}$, Anthony B Rylands ${ }^{3}$, Fiona Maisels ${ }^{8,9}$, Elizabeth A Williamson ${ }^{9}$, Julio Bicca-Marques ${ }^{10}$, Agustin Fuentes ${ }^{11}$, Leandro Jerusalinsky ${ }^{12}$, Steig Johnson ${ }^{13}$, Fabiano Rodrigues de Melo ${ }^{14}$, Leonardo Oliveira ${ }^{15}$, Christoph Schwitzer ${ }^{16}$, Christian Roos ${ }^{17}$, Susan M Cheyne ${ }^{18}$, Maria Cecilia Martins Kierulff ${ }^{19}$ ， Brigitte Raharivololona ${ }^{20}$, Mauricio Talebi ${ }^{21}$ ， Jonah Ratsimbazafy ${ }^{22}$, Jatna Supriatna ${ }^{23}$, Ramesh Boonratana ${ }^{24}$, Made Wedana ${ }^{25}$, Arif Setiawan ${ }^{26}$

1 Institute of Biology, National Autonomous University of Mexico (UNAM), Mexico City, Mexico

Department of Anthropology, University of Illinois at Urbana-Champaign, Urbana, Illinois, United States

3 Global Wildlife Conservation, Austin, Texas, United States

4 School of Natural Sciences and Psychology and Institute for Biodiversity and Ecosystem Dynamics,, Liverpool John Moores University and University of Amsterdam, Liverpool, United Kingdom

5 Department of Ecology, Federal University of Sergipe, São Cristóvão, Brazil

6 Department of Zoology, Federal University of Bahia, Salvador, Brazil

7 Department of Social Sciences, Oxford Brookes University, Oxford, United Kingdom

8 Global Conservation Program, Wildlife Conservation Society, New York, United States

9 Faculty of Natural Sciences, University of Stirling, Stirling, Scotland, United Kingdom

10 Pontifícia Universidade Católica do Rio Grande do Sul, Porto Alegre, Brazil

11 Department of Anthropology, University of Notre Dame, Notre Dame, United States

12 Instituto Chico Mendes de Conservação da Biodiversidade, Ministério do Meio Ambiente, Brasilia, Brazil 13

14

15 Departamento de Ciências, Faculdade de Formação de Professores, Universidade do Estado do Rio de Janeiro (DCIEN/FFP/UERJ), Rio de Janeiro, Brazil

16 Bristol Zoological Society, Bristol, United Kingdom

17 Deutsches Primatenzentrum, Leibniz Institute for Primate Research, Göttingen, Germany

18 1) Borneo Nature Foundation, Palangka Raya, Indonesia, 2) Oxford Brookes University, Oxford, UK., Palangka Raya; Oxford, Indonesia; UK

19 Universidade Federal do Espírito Santo, Instituto Pri-Matas and Centro Universitário Norte do Espírito Santo, Belo Horizonte, Brazil

20 Mention Anthropobiologie et Développement Durable, University of Antananarivo, Antananarivo, Madagascar

21 Universidade Federal de São Paulo, Diadema, São Paulo, Brazil

22

22 Groupe d'étude et de recherche sur les primates (Gerp), Antananarivo, Madagascar

23 Graduate Program in Conservation Biology, Department of Biology FMIPA, University of Indonesia, Depok, Indonesia

24 Mahidol University International College, Salaya, Nakhon Pathom, Thailand

25 The Aspinall Foundation - Indonesia Program, Bandung West Java, Indonesia

26 SwaraOwa, Coffee and Primate Conservation Project, Java, Central Java, Indonesia

Corresponding Author: Alejandro Estrada

Email address: aestradaprimates@gmail.com

Primates occur in 90 countries, but four-Brazil, Madagascar, Indonesia, and the Democratic Republic of the Congo (DRC)-harbor $65 \%$ of the world's primate species (439) and $60 \%$ of these primates are Threatened, Endangered, or Critically Endangered (IUCN Red List of Threatened Species 2017-3). Considering their importance for global primate 
conservation, we examine the anthropogenic pressures each country is facing that place their primate populations at risk. Habitat loss and fragmentation are main threats to primates in Brazil, Madagascar and Indonesia. However, in DRC hunting for the commercial bushmeat trade is the primary threat. Encroachment on primate habitats driven by local and global market demands for food and non-food commodities hunting, illegal trade, the proliferation of invasive species, and human and domestic-animal borne infectious diseases cause habitat loss, population declines, and extirpation. Modeling agricultural expansion in the 21st century for the four countries under a worst-case-scenario, showed a primate range contraction of $78 \%$ for Brazil, $72 \%$ for Indonesia $62 \%$ for Madagascar and $32 \%$ for DRC. These pressures unfold in the context of expanding human populations with low levels of development. Weak governance across these four countries may limit effective primate conservation planning. We examine landscape and local approaches to effective primate conservation policies and assess the distribution of protected areas and primates in each country. P rimates in Brazil and Madagascar have $38 \%$ of their range inside protected areas, $17 \%$ in Indonesia and $14 \%$ in DRC, suggesting that the great majority of primate populations remain vulnerable. We list the key challenges faced by the four countries to avert primate extinctions now and in the future. In the short term, effective law enforcement to stop illegal hunting and illegal forest destruction is absolutely key. Long-term success can only be achieved by focusing local and global public awareness, actively engaging with international organizations, multinational businesses and consumer nations to reduce unsustainable demands on the environment. Finally, the four primate range states need to ensure that integrated, sustainable land-use planning for economic development includes the maintenance of biodiversity and intact, functional natural ecosystems. 
1 Review Article

2

3 Primates in peril: the significance of Brazil, Madagascar, Indonesia 4 and the Democratic Republic of the Congo for global primate 5 conservation

6

Alejandro Estrada ${ }^{1}$, Paul A. Garber ${ }^{2}$, Russell A. Mittermeier ${ }^{3}$, Serge Wich ${ }^{4}$, Sidney Gouveia ${ }^{5}$, Ricardo Dobrovilski ${ }^{6}$, K. Anne-Isola Nekaris 7, Vincent Nijman ${ }^{8}$, Anthony B. Rylands ${ }^{9}$, Fiona Maisels ${ }^{10}$, Elizabeth A. Williamson ${ }^{11}$ Julio Cesar Bicca-Marques ${ }^{12}$, Agustin Fuentes ${ }^{13}$, Leandro Jerusalinsky ${ }^{14}$, Steig Johnson ${ }^{15}$, Fabiano Rodriguez de Melo ${ }^{16}$, Leonardo Oliveira ${ }^{17}$, Christoph Schwitzer ${ }^{18}$, Christian Roos ${ }^{19}$, Susan M. Cheyne ${ }^{20}$, Maria Cecília Martins Kierulff ${ }^{21}$, Brigitte Raharivololona $^{22}$, Maurício Talebi ${ }^{23}$, Jonah Ratsimbazafy ${ }^{24}$, Jatna Supriatna ${ }^{25}$, Ramesh Boonratana $^{26}$, Made Wedana ${ }^{27}$, Arif Setiawan ${ }^{28}$

${ }^{1}$ Alejandro Estrada, Institute of Biology, National Autonomous University of Mexico, Mexico City, Mexico. Email: <aestradaprimates@gmail.com>.

${ }^{2}$ Paul A. Garber, Department of Anthropology, University of Illinois, Urbana, IL, USA. Email: $<\mathrm{p}-$ garber@illinois.edu>.

${ }^{3}$ Russell A. Mittermeier, Global Wildlife Conservation, Austin, TX, USA. Email:

$<$ rmittermeier@globalwildlife.org>.

${ }^{4}$ Serge Wich, School of Natural Sciences and Psychology, Liverpool John Moores University and Institute for Biodiversity and Ecosystem Dynamics, University of Amsterdam. Email:

s.a.wich@ljmu.ac.uk.

${ }^{5}$ Sidney Gouveia, Department of Ecology, Federal University of Sergipe, São Cristóvão, Brazil. Email: <sgouveia@ufs.br>

${ }^{6}$ Ricardo Dobrovolski, Department of Zoology, Federal University of Bahia, Salvador, Brazil. Email: <rdobrovolski@gmail.com>

${ }^{7}$ K. A. I. Nekaris, Department of Social Sciences, Oxford Brookes University, Oxford, U.K. Email: <anekaris@brookes.ac.uk>

${ }^{8}$ Vincent Nijman, Department of Social Sciences, Oxford Brookes University, Oxford, U.K. Email:

<vnijman@brookes.ac.uk>

${ }^{9}$ Anthony B. Rylands, Global Wildlife Conservation, Austin, TX, USA. Email:

<arylands@globalwildlife.org>

${ }^{10}$ Fiona Maisels, Wildlife Conservation Society, Global Conservation Program, New York, U.S.A, and Faculty of Natural Sciences, University of Stirling, FK9 4LA, Scotland, U.K. Email: fmaisels@wcs.org ${ }^{11}$ Elizabeth A. Williamson, Faculty of Natural Sciences, University of Stirling, Scotland, UK. Email: $<$ e.a.williamson@stir.ac.uk>

${ }^{12}$ Júlio César Bicca-Marques, Julio Pontifícia Universidade Católica do Rio Grande do Sul, Porto Alegre, Brasil.Email: <jcbicca@pucrs.br>

${ }^{13}$ Agustin Fuentes, Department of Anthropology, University of Notre Dame, Notre Dame, IN, USA.

Email:<afuentes@nd.edu>

${ }^{14}$ Leandro Jerusalinsky, Instituto Chico Mendes de Conservação da Biodiversidade, Ministério do Meio

Ambiente, Brazil. Email: <leandro.jerusalinsky@icmbio.gov.br>, <ljerusalinsky@gmail.com>

${ }^{15}$ Steig Johnson, Department of Anthropology and Archaeology, University of Calgary, Calgary, Canada.

Email: steig.johnson@ucalgary.ca 
$47{ }^{16}$ Fabiano Rodrigues de Melo, Universidade Federal de Goiás, and Dept. Eng. Florestal, Campus UFV, 48 UFV Jatai, Viçosa, Brazil. Email: <fabiano_melo@ufg.br>

$49{ }^{17}$ Leonardo Oliveira, Departamento de Ciências, Faculdade de Formação de Professores, Universidade do 50 Estado do Rio de Janeiro (DCIEN/FFP/UERJ). Email: leonardoco@gmail.com

51 18 Christoph Schwitzer, Bristol Zoological Society, Bristol, UK. Email: <cschwitzer@bristolzoo.org.uk>

$52{ }^{19}$ Christian Roos, Deutsches Primatenzentrum, Leibniz Institute for Primate Research, Göttingen,

53 Germany. Email: <croos@dpz.eu>

$54{ }^{20}$ Susan M. Cheyne, 1) Borneo Nature Foundation, Palangka Raya, Indonesia, 2) Oxford Brookes

55 University, Oxford, UK. Email: <s.cheyne@borneonature.org>

$56{ }^{21}$ Maria Cecilia Martins Kierulff, Universidade Federal do Espírito Santo, Instituto Pri-Matas and Centro

57 Universitário Norte do Espírito Santo, Brazil. Email: <ceciliakierulff@gmail.com>.

$58 \quad{ }^{22}$ Brigitte Raharivololona, Mention Anthropobiologie et Développement Durable, University of

59 Antananarivo. Email: <raharivololonabrigitte@yahoo.fr>

60 23Maurício Talebi, Universidade Federal de São Paulo, Diadema, São Paulo, Brazil. Email:

$61<$ talebi40@gmail.com>

$62{ }^{24} J$ Jonah Ratsimbazafy, Groupe d'étude et de recherche sur les primates (Gerp), Antananarivo,

63 Madagascar. Email: <jonah@gerp-mg.org>

$64{ }^{25}$ Jatna Supriatna, Graduate Program in Conservation Biology, Department of Biology, FMIPA,

65 University of Indonesia, Depok, Indonesia. Email: <jatna.supriatna@gmail.com>,

$66<$ jatna.suprijatna@rccc.ui.ac.id>.

$67{ }^{26}$ Ramesh Boonratana, Mahidol University International College, Salaya, Nakhon Pathom 73170,

68 Thailand. Email: <rboonratana@gmail.com>,<ramesh.boo@mahidol.ac.th>.

$69{ }^{27}$ Made Wedana, The Aspinall Foundation - Indonesia Program, Bandung West Java, Indonesia. Email:

$70<$ madewedana@hotmail.com>

$71{ }^{28}$ Arif Setiawan: SwaraOwa, Coffee and Primate Conservation Project, Centra Java, Indonesia. Email:

$72<$ wawan5361@gmail.com>

73

74

75

76

77

78

79

80

81
Corresponding authors:

${ }^{1}$ Alejandro Estrada, Institute of Biology, National Autonomous University of Mexico, Mexico City, Mexico. Email: <aestradaprimates@gmail.com>.

${ }^{2}$ Paul A. Garber, Department of Anthropology, University of Illinois, Urbana, IL, USA. Email: $<$ p-garber@illinois.edu>. 
82

83

84

85

86

87

88

89

90

91

92

93

94

95

96

97

98

99

100

101

102

103

104

105

106

107

108

109

110

111

112

\section{ABSTRACT}

Primates occur in 90 countries, but four-Brazil, Madagascar, Indonesia, and the Democratic Republic of the Congo (DRC) - harbor 65\% of the world's primate species (439) and 60\% of these primates are Thretened, Endangered, or Critically Endangered (IUCN Red List of Threatened Species 2017-3). Considering their importance for global primate conservation, we examine the anthropogenic pressures each country is facing that place their primate populations at risk. Habitat loss and fragmentation are main threats to primates in Brazil, Madagascar and Indonesia. However, in DRC hunting for the commercial bushmeat trade is the primary threat. Encroachment on primate habitats driven by local and global market demands for food and nonfood commodities hunting, illegal trade, the proliferation of invasive species, and human and domestic-animal borne infectious diseases cause habitat loss, population declines, and extirpation. Modeling agricultural expansion in the 21 st century for the four countries under a worst-case-scenario, showed a primate range contraction of $78 \%$ for Brazil, $72 \%$ for Indonesia $62 \%$ for Madagascar and 32\% for DRC. These pressures unfold in the context of expanding human populations with low levels of development. Weak governance across these four countries may limit effective primate conservation planning. We examine landscape and local approaches to effective primate conservation policies and assess the distribution of protected areas and primates in each country. Primates in Brazil and Madagascar have $38 \%$ of their range inside protected areas, $17 \%$ in Indonesia and 14\% in DRC, suggesting that the great majority of primate populations remain vulnerable. We list the key challenges faced by the four countries to avert primate extinctions now and in the future. In the short term, effective law enforcement to stop illegal hunting and illegal forest destruction is absolutely key. Long-term success can only be achieved by focusing local and global public awareness, actively engaging with international organizations, multinational businesses and consumer nations to reduce unsustainable demands on the environment. Finally, the four primate range states need to ensure that integrated, sustainable land-use planning for economic development includes the maintenance of biodiversity and intact, functional natural ecosystems. 
113

114

115

116

117

118

119

120

121

122

123

124

125

126

127

128

129

130

131

132

133

134

135

136

137

138

139

140

141

142

143

144

145

146

147

148

149

150

151

152

153

154

155

156

\section{INTRODUCTION}

A recent evaluation of primate species worldwide indicated that more than half are facing nearterm extinction due to unsustainable human activities (Estrada et al., 2017). According to the IUCN Red List, wild primates occur in 90 countries across the Neotropics, Africa, and Asia. Sixty-five per cent of primate species (286 of 439 species), however, are found in only four countries, - Brazil, Madagascar, Indonesia, and the Democratic Republic of the Congo (DRC) (IUCN, 2017). Based on a comprehensive literature review, we compare the anthropogenic pressures faced by each of these four countries that place primate populations at risk, analyzing differences and similarities affecting land cover changes caused by agricultural expansion, mining and fossil fuel extraction, and local and international trade demands for food and nonfood commodities. We discuss the impact of bushmeat hunting, illegal trade and zoonotic, human and domestic-animal borne infectious diseases on primate population persistence. This information is analyzed within the context of an increasing human population with low levels of human development, income inequality, political instability, and weak governance. We model the expansion of agricultural during the $21^{\text {st }}$ century and identify areas of expected spatial conflict between new crop production and primate distributions in each country. We provide an examination of the conservation value of protected areas, of habitat restoration, and forest connectivity at the landscape level, and stress the importance of community managed forests, where appropriate, for primate conservation at the local level. We further discuss socially oriented conservation actions by NGOs and governments for averting local primate extinction. In our conclusion, we discuss the multiple challenges faced by Brazil, Madagascar, Indonesia and DRC, as well as the global community to ensure the conservation of their unique primate fauna.

\section{Survey methodology}

We conducted a thorough (at the time of writing) review of the peer-reviewed scientific literature. We integrated the most recent evaluation for primate species conservation status in each country from the International Union for the Conservation of Nature (IUCN, 2017) and information from Global Forest Watch, along with the published literature, to evaluate trends in forest loss between 2001 and 2016 in each country and its effect as a major threat to primate survivorship. Information from FAO (Food and Agriculture Organization of the UN) was used to profile industrial agriculture expansion in the four countries for the same period. We complement these results with a summary of spatial conflict between primate species' distributions and predicted agricultural expansion during the $21^{\text {st }}$ century for each country. Species distributions were obtained from the IUCN range maps (IUCN, 2017). Agricultural expansion is derived from remote sensing data from IMAGE (Integrated Model to Assess the Global Environment; http://themasites.pbl.nl/models/image/index.php/Agricultural_economy) and represents the predicted presence (irrespective of the intensity) of agricultural production at each grid cell $\left(0.5^{\circ}\right.$ of spatial resolution; see Dobrovolski et al., 2014). We document the pressures exerted by international commodities trade on primate habitat loss and degradation using information from the International Trade Centre (http://www.intracen.org_). Legal and illegal primate trade was documented from the CITES (Convention on International Trade in Endangered Species of Wild Fauna and Flora) trade database and from published reports. Information on human population growth and socioeconomic metrics in each country was profiled with information from FAO and the World Bank. Civil conflict and quality of governance indicators for each country were 
157

158

159

160

161

162

163

164

165

166

167

168

169

170

171

172

173

174

175

176

177

178

179

180

181

182

183

184

185

186

187

188

189

190

191

192

193

194

195

196

197

198

199 obtained from the $\mathbf{2 0 1 7}$ Global Peace Index of the Institute for Economics and Peace (http://economicsandpeace.org/) and from the World Bank. We assessed the distribution of protected areas and primate ranges in the four countries using information from the Protected Planet of the UN Environmental Program UNEP-WCMC (2017), the IUCN Red List, and forest cover data from Hansen et al., 2013. We included 2190 protected areas in the Brazil dataset, 49 in DRC, 147 in Madagascar and 646 in Indonesia (Text S1). We gather information on the 2016 Corruption Perceptions Index (CPI) of Transparency International (https://www.transparency.org) for each country and obtained, from the World Bank, average values for the four countries of four indicators of governance quality in 2016

(http://info.worldbank.org/governance/wgi/index.aspx\#reports). We compared these to the average values for 35 high-income countries

We are aware that some of the datasets we consulted vary in their level of reliability an objectivity. For example, some data from FAO and the World Bank are based on information provided directly by host governments, and therefore may be incomplete or reflect broad estimates. Similarly, data from the IUCN on the population size, distribution, and conservation status of certain rare, cryptic, or highly inaccessible primate species are based on surveys or census methods that may vary in completeness, and therefore final determinations are subject to a consensus based on "expert opinion". In other cases, the data are obtained through careful monitoring by an agency (e.g. International Trade Centre, Transparency International) or were independently corroborated using remote sensing to add increased reliability (e.g., Global Forest Watch, IMAGE, Protected Planet). Each of the agencies we used as sources of information stipulate in their portals the limitation of the data they presented (see Text S1 for a list and the relevant URLs). We note that although the numbers reported may vary in their level of accuracy, the trends within and between each country are consistent with high confidence.

\section{Richness of primate species and IUCN threatened status and population status} While Brazil, Madagascar, Indonesia and DRC differ significantly in their human population demography, culture, history, and economy, they are important reservoirs for the world's biodiversity, with each considered a megadiverse country (Mittermeier, Robles Gil \& Mittermeier, 1997; Table S1, Text S1). They also harbor a nonoverlapping and significant share $(65 \% ; n=286$ species $)$ of the world's nonhuman primate species $(n=439$ species $)$ : Brazil -102 primate species, 17 genera; Madagascar - 100, 15 genera; Indonesia - 48, 8 genera; and DRC 36, 15 genera. This includes 55 genera and all 16 recognized nonhuman primate families (IUCN, 2017; Table S2, Fig. 1). Each country's primate population is imperiled by the expanding pressures of human activities and, as a group, $62 \%$ of their primate species are Threatened (i.e. assessed as either Vulnerable, Endangered or Critically Endangered on the IUCN Red List) and $60 \%$ are declining (IUCN, 2017; Fig. 1). The two countries with the greatest number of Threatened and declining primate species are Madagascar and Indonesia followed by Brazil and DRC (Fig. 1).

\section{Large-scale encroachment and loss of primate habitats}

\section{Trends in forest loss}

Habitat loss is a major driver of local extirpation of primate species. Using information from the Global Forest Watch database ( GFW, 2018; Hansen et al., 2013) we found a general increase in 
200 loss of forest (defined as $>30 \%$ canopy cover), for the period 2001 to 2016 in all four countries 201 (Fig. 2A). Total forest loss for the period was 46.43 M ha for Brazil, 23.08 $\mathrm{M}$ ha for Indonesia, $20210.52 \mathrm{M}$ ha for DRC and 2.75 M ha for Madagascar (Fig. 2B; Table S3). Brazil's initiatives to 203 combat deforestation resulted in important reductions in forest loss (80\%) from 2005 to 2012 204 (Fig. 2; Nepstad et al., 2014; PRODES, 2018), although in biomes such as the dry forests of the 205 Cerrado, deforestation continued at high rates (Strassburg et al., 2017). Unfortunately, 206 deforestation in Brazil increased sharply in 2016 (Fig. 2 A, B), probably the result of a shift in

Importantly, between 2000 and 2013 each of the four countries experienced losses in their remaining area of Intact Forest Landscapes (IFL; Potapov et al., 2017). The largest percent of IFL losses occurred in Madagascar and Indonesia, followed by Brazil and DRC (Table 1). These trends highlight important reductions in primate habitats that are exacerbated by increases in low-density, small-scale deforestation, which is more difficult to identify and track (Kalamandeen et al., 2018). For example, in Amazonia, the number of new small clearings $(<1$ ha) increased by $34 \%$ between 2001-2007 and small-scale low-density forest loss ( $\mathrm{km}^{2}$ forest loss per $100 \mathrm{~km}^{2}$ ) expanded markedly between 2008-2014. Overall, cleared forest patches less than 6.25 ha accounted for $\sim 34 \%$ of the total Brazilian Amazon forest lost between 2001 and 2014, including in forest loss in reserves that are described as protected areas (Kalamandeen et al., 2018). In 2000, DRC was reported to have almost $2 \mathrm{M} \mathrm{km}^{2}$ of forest ( $>30 \%$ canopy cover) (GFW, 2018). Of this, 32\% was classified as Intact Forest Landscape (Potapov et al., 2017) and (36\%) as hinterland forests (minimally disturbed forests, Tyukavina et al., 2013). Between 2000 and 2013, 4.2\% of DRC's intact forests were lost (Table 1; Potapov et al., 2017), and in total $5.3 \%$ of the country's total forest was lost between 2001 and 2016 (GFW, 2018). Over the past 5 years, DRC has experienced a mean annual forest loss of approximately $0.5 \%$, the lowest of the four countries in this analysis.

Wide range tropical deforestation also results in forest fragmentation, leading to higher extinction rates in local populations (Hanski et al., 2013). A recent study predicts that additional forest loss will result in a large increase in the total number of forest fragments in the Neotropics, Africa and Asia, accompanied by a decrease in their size (Taubert et al., 2018). In general, extinction risk increases with decreasing fragment size (Hanski et al., 2013).

\section{Trends in expansion of agricultural land}

Keeping in mind the limitations of statistics reported by the Food and Agriculture Organization of the United Nations (information provided to the FAO comes directly from host governments who may provide incomplete data), from 2001 to 2015 the combined estimated increase of agricultural land in Brazil, Madagascar, Indonesia, and DRC totaled some $29.5 \mathrm{M}$ ha (see Text S1, Fig S1, Table S4), with Brazil having the largest increase (19.1 M ha) followed by Indonesia (9.3 M ha), DRC (650 K ha), and Madagascar ( $572 \mathrm{~K} \mathrm{ha)} \mathrm{(Table} \mathrm{S4)} \mathrm{(for} \mathrm{estimates} \mathrm{of} \mathrm{trends} \mathrm{in}$ the production of key crops in each country for the period 2001-2015 see Fig. S2 to S5 and Text S1). The agricultural footprint (increase of agricultural area as percent of land area, based on data from FAO and the World Bank; Table S4) for this period was 4.89\% for Indonesia, 2.25\% for Brazil, $0.97 \%$ for Madagascar, and $0.28 \%$ for DRC. In the case of DRC, a higher footprint estimate of $1.20 \%$ has been reported for rural areas (period from 2000-2010) resulting in the addition of $2.77 \mathrm{M}$ ha of rural roads, villages, and active and abandoned fields and gardens. This 
246

rural complex accounted for 13.1\% of DRC's total land area in 2015 (Molinario et al., 2015). Between 2000-2010, the overall loss of "core forest" (which made up 36.6\% of the 2010 land area) to perforated forest, patch forest, fragmented forest or edge was estimated at $3.8 \%$ (Molinario et al. 2017). The main cause of forest loss in DRC (92\%) was shifting cultivation (Molinario et al., 2017).

\section{Projected agricultural expansion and primate range contraction in the $21^{\text {st }}$ century}

Increases in species extinction risk are typically related to the loss of individual populations and associated declines in their geographical range (Ceballos \& Ehrlich, 2002; Wolf \& Ripple, 2017). A global study modeling conflict between agricultural expansion and primate species' distributions predicted that during the $21^{\text {st }}$ century, regions expected to be converted from forest to agricultural production account for $68 \%$ of the area currently used by primates, and that worldwide this will lead to unsustainable spatial conflict for $75 \%$ of primate species (Estrada et al., 2017). Modeling agricultural expansion in the $21^{\text {st }}$ century for the four countries under a worst-case-scenario, shows a primate range contraction of $78 \%$ for Brazil, $72 \%$ for Indonesia, $62 \%$ for Madagascar and 32\% for DRC (Figs. 3, 4). A business-as-usual scenario also predicts high spatial conflict while an optimistic scenario predicts significantly lower spatial conflict (Fig. S6). This suggests that targeted policies designed to shift agricultural expansion to already altered landscapes in order to minimize habitat fragmentation and loss of existing forest is critical in limiting spatial conflicts in each country (Dobrovolski et al., 2013, 2014). Global dietary changes, towards eating more meat, greater dependence on vegetable oils, and, to a lesser extent, more coffee, tea, among others. as countries develop, will require these primate-rich countries to convert additional forested land into monocultures to meet local and global market demands (Kastner et al. 2012; Tilman \& Clark, 2014). Other threats such as hunting, logging, mining, fossil fuel extraction, anthropogenic infectious diseases, and climate change also are expected to result in primate range contraction (see below).

\section{Other large-scale stressors}

\section{Logging, mining and fossil fuel extraction and primate habitat loss and degradation}

Since the 1980s, the extraction of hardwoods has increased in the four countries in response to an ever-expanding worldwide demand for tropical timber (Estrada, 2012). This has resulted in deforestation and new economic incentives to construct roads in forested areas (Alamgir et al., 2017). Although some primate species can survive temporarily in logged forests, both legal and illegal logging result in a decrease of canopy cover, reduced humidity in the subcanopy and undergrowth that increases tree mortality, the incidence of ground fires, a decline in forest undergrowth, and negatively impacts the regeneration of large tree species that provide food, resting sites, and refuge for primates (Alisjahbana \& Busch, 2017; Lewis, Edwards \& Galbraith, 2015; Peres, 1999, 2001; World Bank, 2010) (Text S1).

Mining is a persistent threat to primates and their habitats. The mining of precious gems and minerals contributes to habitat destruction, fragmentation, deforestation, and the poisoning and pollution of soil and ground water (Alvarez-Berrios \& Aide, 2015). In addition, mining (and fossil fuel extraction, see below) stimulates human migration, the illegal logging and colonization of forested areas, hunting, and the construction of roads and railways (Alamgir et al., 2017; Butt et al., 2013; Laurance et al., 2015). In eastern DRC, there is an unfortunate overlap of unprotected areas of high animal and plant biodiversity with areas that are rich in 
292

293

294

295

296

297

298

299

300

301

302

303

304

305

306

307

308

309

310

311

312

313

314

315

316

317

318

319

320

321

322

323

324

325

326

327

328

329

330

331

332

333

334

335

336

337

minerals (Edwards et al., 2014). Increased global demand for easily-mined surface deposits of tantalum, a rare earth metal used in electronics including cell phones, has resulted in the expansion of illegal mining camps in several national parks in DRC. Bushmeat hunting in this area has decimated several primate populations (e.g., Grauer's gorillas, and eastern chimpanzees; Plumptre et al., 2015; Spira et al., 2017). Of the existing 1249 mining prospection permits in DRC, $952(76 \%)$ have their centers in the rural complex (areas that have been in the cycle of slash-and-burn agriculture for at least 18 years). Permits in the rural complex cover 143,316 km², which is $78 \%$ of the total permitted area. The mean area of mining permits is $150 \mathrm{~km}^{2}$ (and there is no difference between the size of permitted area in the rural complex and in forests more distant from human settlement). Approximately one quarter of the mining prospection permits are located inside the forest and, if these are opened up for mineral extraction, they will pose a grave threat to primates (see Text $\mathrm{S} 1$ ).

In Madagascar, the illegal mining of nickel, cobalt, gold, and precious gems (sapphire) has affected many forests, including protected areas with an important negative impact on populations of Malagasy primates including the iconic ring-tailed lemur (Lemur catta) (Gould \& Sauther, 2016). In Brazil, between 2001 and 2013 approximately 1,680 km² of tropical moist forest was lost across 1600 gold mining sites, including significant forest loss inside 13 protected areas (Alvarez-Berríos \& Aide, 2015). A more recent study showed that between 2005 and 2015 mining in Brazil significantly increased Amazon forest loss up to $70 \mathrm{~km}$ beyond mining lease boundaries, causing 11,670 $\mathrm{km}^{2}$ of deforestation (9\% of all Amazon forest loss during this period) (Sonter et al., 2017). The disposal of mining waste is a significant threat to the local biota, including primates. In Brazil, for example, 126 mining dams are currently at risk of failing. In one such case, dam failure poisoned hundreds of kilometers of the Doce River with toxic mud (Garcia et al., 2017). In Kalimantan, Indonesia, gold mining is a major threat to the proboscis monkey (Nasalis larvatus) (Meijaard \& Nijman, 2000) and to Bornean orangutans and Bornean gibbons (Hylobates muelleri) (Lanjouw, 2014). From 2000-2010, some 3,000 km² of, mostly lowland, forest in Indonesia was lost due to logging and as of 2011 , over $40,000 \mathrm{~km}^{2}$ of additional land was allocated to mining concessions (Abood et al., 2015). Most of these concessions are located on the islands of Sumatra and Borneo, where it directly impedes with conservation efforts to protect arboreal primates such as the slow loris (Nycticebus spp.), langurs (Presbytis spp. and Trachypithecus spp.), gibbons (Hylobates spp.), siamangs (Symphalangus syndactylus) and orangutans (Pongo spp.). For some species such as the western tarsier (Tarsius bancanus) and Sody's slow loris (Nycticebus bancanus) on the island of Belitung (Yustian, 2007), finding a way to manage tin mines using environmentally friendly approaches is crucial for the survival of these nocturnal primates. In addition, traditional methods of gold mining and limestone karst mining now threaten the habitat of the agile gibbon (Hylobates agilis), the siamang, the black-crested Sumatran langur (Presbytis melalophos) and the silvered langur (Trachypithecus cristatus) in the province of Jambi in West Sumatra. Miners living in these areas also exploit primates and other wildlife for meat and capture live primates for pets that are sold in local towns (see hunting and illegal trade below; Agustin et al., 2016; Yanuar, 2009).

Fossil fuel extraction negatively impacts primate survivorship. For example, over the next 20 years, the global demand for oil is expected to increase by over $30 \%$ and the expected increase in natural gas by 53\% from 2014 levels (Butt et al., 2013; Finer et al., 2015). This peak oil production it is projected to fall to present day levels (due to the changeover to electric vehicles) 
338 by the year 2040 (Longley 2018). Brazil, Indonesia, and Madagascar are already expanding 339 concessions and exporting this commodity (The International Trade Center - www.intracen.org). 340 In the western Amazon of Brazil, for example, such concessions include national parks and

\section{territories of indigenous peoples (Finer et al., 2015). In DRC, oil concessions now cover almost} all of the Albertine Rift and much of the central basin, where a concentration of endemic primate taxa is found (Ministère Hydrocarbures DRC, 2013).

\section{International commodities trade and loss and degradation of primate habitat}

International trade commodity-driven deforestation is increasingly caused by global demand for agricultural and nonfood commodities (e.g., soy, beef, palm oil, timber, ores, fossil fuel) negatively impacting tropical biodiversity (Henders et al., 2015; Henders et al., 2018) and primate range and population persistence (Estrada et al 2017). While the growing human populations in Brazil, Madagascar, Indonesia and DRC (see "Human population" below) have resulted in increased internal demands for food and non-food commodities, global market pressures from highly industrialized nations are significant drivers of rapid and widespread habitat loss. According to the International Trade Centre, these four primate-rich countries sell at least $50 \%$ of all exports of raw materials to China, the US, Canada, India, and several European countries (Table 2). Commodities such as frozen beef, soy, sugar cane, hardwoods, and ores are principal exports of Brazil; in DRC minerals are the primary global export commodity, followed by smaller amounts of hardwoods, natural rubber, coffee, and cacao; for Madagascar, major exports are minerals, coffee, tea, spices, hardwood, and vegetable and roots/tubers; and for Indonesia, rice, natural rubber, oilseeds, and wood (Text S1). In Brazil, $30 \%$ of deforestation between 2000 and 2010 was driven by global demands for beef and soy exports (Karstensen, Peters \& Andrew, 2013). Given that segments of the human population in each of these countries are undernourished (see "Human population" below), the exportation of food may threaten local food security, human safety and political stability (FAO, IFAD \& WFP, 2015). The growing and unsustainable global demand for food and non-food crops, wood, fossil fuel, minerals, and gems by a small number of consumer nations has resulted in a rapid increase in agricultural production, wood extraction, itinerant miners, and oil/gas extraction. This also has led to an expansion of road networks and hydropower development in all four countries (Alamgir et al., 2017), ensuing increased forest loss, illegal colonization and logging, increases in itinerant mining and increases in primate hunting and trade (Estrada et al., 2017; Latrubesse et al., 2017; Plumptre et al 2015; Spira et al., 2017; Timpe \& Kaplan, 2017; Winemiller et al., 2016). Importing nations process the raw materials and the final product is commercialized for local and global consumption. A particulary unfortunate example of this is the growing global demand for products produced by industrialized nations such as cell phones, laptops and other electronic devices using conflict minerals such as coltan, mined in DRC (Hayes \& Burge, 2003; Mancheri et al., 2018; Spira et al., 2017). To balance global market demands with the needs of the four primate-rich countries to develop their internal economies, ensure food security, and improve the standard of living for their expanding human populations, the 'greening' of trade can promote environmental protection (Neumayer, 2001; Henders et al., 2018). International corporations should add these costs to products so that there is a continuous regeneration of funds to sustainably promote conservation (Butler \& Laurance, 2008). Alternatively, the World Bank or UN could require that corporations and consumer nations pay into a sustainability/conservation fund based on their levels of consumption and environmental damage (e.g., like a carbon tax; Carbon Tax Center https://www.carbontax.org; consulted August 2017). In countries in which 
384

385

386

387

388

389

390

391

392

393

394

395

396

397

398

399

400

401

402

403

404

405

406

407

408

409

410

411

412

413

414

415

416

417

418

419

420

421

422

423

424

425

426

427

428

429

the rural poor depend on forest products, community forest management could bridge or integrate the needs of conservation and commodity production, sustainably safeguarding the continued integrity of complex ecological systems (Sharif \& Saha, 2017). The recent environmentally-oriented, demand-side policies regarding illegal timber imports by the EU ( $E U$, $2010)$, the EU resolution on oil palm production and deforestation $(E P, 2017)$, and the Amsterdam Declaration to eliminate deforestation from agricultural commodity chains (Amsterdam, 2015) represent important and positive 'green' changes that need to be adopted by the U.S., China, and other consume nations. However, the continued growth of the global demand for forest-risk agricultural and nonfood commodities requires additional legislation and a stronger global effort at regulating the negative impact of unsustainable commodity trade (Henders et al., 2018).

\section{Local-scale anthropogenic threats to primate populations}

\section{Hunting}

Hunting (for meat and culturally valued body parts) negatively impacts $54 \%$ to $90 \%$ of primate species in the Neotropics, Africa, Madagascar, and Asia (Estrada et al., 2017). According to IUCN, about $85 \%$ of primate species in Indonesia are hunted, $64 \%$ in Madagascar, $51 \%$ in DRC and $35 \%$ in Brazil (IUCN, 2017) but we need to recognise that the IUCN primate assessments are now ten years old and many do not mention hunting specifically. The new assessments of the African primates (which will come online in 2018) are in general much clearer regarding individual threats and a much higher percentage - at least in Africa- will list hunting as a primary threat than in previous assessments. In reality, for example, almost all primates in DRC are hunted- even the smallest monkey, the talapoin has now been recorded at bushmeat markets (Bersacola et al., 2014). An exception is the nocturnal strepsirrhines, which are so small and so hard to catch that they are rarely taken unless for traditional medicine). Commercialized bushmeat hunting is a primary driver of primate population reduction and, in the case of the Brazilian Amazon, has led to the extirpation of highly endangered taxa such as spider monkeys (Ateles spp.) and woolly monkeys (Lagothrix spp.) (Effiom et al., 2013; Peres et al., 2016; Stevenson \& Aldana, 2008). Hunting has contributed to extirpation of smaller and threatened primates in the Atlantic Forest such as the yellow-breasted capuchin monkey (Sapajus xanthosternos), Coimbra-Filho's titi monkey (Callicebus coimbrai) (Canale et al., 2012; Hilário et al., 2017) and the largest Neotropical primate species, the southern muriquis (Brachyteles arachnoides) (Talebi et al., 2011). In DRC hunting has significantly reduced the numbers of gorillas and bonobos (Hickey et al., 2013; Plumptre et al., 2016c). In a wild meat market in Kisangani (DRC) about 65 primates were traded per day over a 131-day period (about 8, 515 primates/131 days) (Van Vliet et al., 2012). In Basankusu (DRC), the rate was 17 primates traded per visit (Dupain et al., 2012). The primates present in these markets included species of the genera Chlorocebus, Cercocebus, Colobus, as well as chimpanzees and bonobos (Text S1). In DRC, the Endangered or Critically Endangered l'Hoest's Monkey (Allochrocebus lhoesti), Dryas monkey (Cercopithecus dryas) (Fa et al., 2014), Grauer's gorilla (Gorilla beringei graueri) and the eastern chimpanzee (Pan troglodytes schweinfurthii) experience high levels of poaching and are part of the commercial bushmeat trade (Fig. 4, Plumptre et al., 2015, 2016a,b,c; Spira et al,, 2017). In DRC, hunting has resulted in emptying of all but the smallest bodied faunal species across large swathes of forest. For example, a large area of the Sankuru Natural Reserve has almost no bonobos remaining (Liengola et al., 2009); in a survey of the corridor area between the two sectors of the largest national park in the country (Salonga), bonobos were never found 
430

431

432

433

434

435

436

437

438

439

440

441

442

443

444

445

446

447

448

449

450

451

452

453

454

455

456

457

458

459

460

461

462

463

464

465

466

467

468

469

470

471

472

473

474

475

closer than 10 kilometers from the nearest village (Maisels et al., 2009; see Text 1). Given that only $21-27.5 \%$ of bonobos live in protected areas (Hickey et al., 2013), their survival into the next century remains in doubt. However, primates living in protected areas also face significant challenges. Most of the remaining 3,800 Grauer's gorillas and all mountain gorillas Gorilla beringei beringei (estimated population size 880 ) are restricted to protected areas (Plumptre et al., 2016b). Because the population density of lemurs, monkeys, and apes living outside of protected areas has decreased rapidly, this has resulted in an increase in the price or value of primate bushmeat, making it profitable for hunters to risk prosecution by entering into protected areas (Rovero et al., 2012).

Poorer households in the forested northwestern Makira landscape of Madagascar rely more on wildlife than richer households (Golden et al., 2016). Widespread hunting of black-and-white ruffed lemurs (Varecia varecia), diademed sifakas (P. diadema) and the brown lemur (Eulemur fulvus) in eastern Madagascar, has put these primates at increased risk (Jenkins et al., 2011). In periods following political crisis and instability in Madagascar, lemurs were traded as a prized source of meat (Barrett \& Ratsimbazafy, 2009). Larger diurnal species such as the black-andwhite ruffed lemur, indri (Indri indri), and sifaka (Propithecus spp.) are targeted because traditional taboos protecting lemurs have eroded rapidly (Golden, 2009; Jenkins et al., 2011). Even small species such as mouse lemurs (Microcebus spp.) are eaten, with hunters capable of capturing up to 50 a night; the impact on wild populations is considerable (Gardner \& Davies, 2014) (Text S1). Primate bushmeat consumption and trade in southern Sumatra results in hundreds of macaques killed monthly to meet the demand from wild meat restaurants (KSBK, 2002). Other primates eaten are the Sangihe Island tarsiers (Tarsius sangirensis; Shekelle \& Salim, 2009) and Bornean orangutans (Pongo pygmaeus; Meijaard et al., 2011). In Borneo, between 1,950 to 3,100 orangutans are killed annually for consumption (including 375 to 1550 females), significantly impacting the viability of many small isolated populations (Ancrenaz et al., 2016; Meijaard et al., 2011; Santika et al., 2017a). In Indonesia, even subsistence hunting can have major effects on primate populations already decimated by land conversion and habitat loss (orangutans in Sumatra, Kloss' gibbons, pig-tailed langurs, Mentawai Island langurs and populations of Trachypithecus spp. and Presbytis spp. on others Indonesian islands) (Fuentes, 1998, 2002; Paciulli, 2004).

Numerous primates in each of the four countries consume ripe fruits and serve as important agents of seed, dispersal promoting forest regeneration (Chapman et al., 2013). The extirpation of primates due to hunting results in a change in dispersal dynamics, the size and distribution of seed shadows, a reduction in plant genetic diversity and seedling recruitment (Caughlin et., 2015; Pacheco \& Simonetti, 2000; Brodie et al., 2009). There also is evidence that lemur population decline has resulted in the reduced viability of several species of Malagasy trees (Federman et al., 2016). Similarly, the population collapse of larger-bodied primates in response to over-hunting in the Brazilian Amazon has impacted the regeneration of long-lived and hardwood tree species and this is likely to reduce the ability of these forests to store carbon (Peres et al., 2016; Stevenson \& Aldana, 2010). The overhunting of primates reduces the recruitment of trees whose seeds they disperse which also reduces food sources available to the local mammalian and avian communities (Abernethy et al., 2013; Nuñez-Iturri, Olsson \& Howe, 2008). 
476

477

478

479

480

481

482

483

484

485

486

487

488

489

490

491

492

493

494

495

496

497

498

499

500

501

502

503

504

505

506

507

508

509

510

511

512

513

514

515

516

517

518

519

520

521

\section{Legal and illegal primate live trade}

Many primate species are impacted by unsustainable live trade, often organized by criminal networks or sanctioned by local and national governments (Fig. 4, Alves, Souto \& Barboza, 2010; Nijman et al., 2011; Alamgir et al., 2017; Nekaris et al. 2013; Shanee, Mendoza \& Shanee, 2015; UNODC, 2013). According to the CITES trade database, Indonesia is the leading exporter of live primates, with $98 \%$ being either captive-bred or captive-born long-tailed macaques (Macaca fascicularis) and the remainder principally wild-caught animals from a number of other species (Table 3). Most of the international trade from Indonesia is for scientific or biomedical research ( $V$. Nijman, unpublished data based on CITES trade data). In DRC, over the last decade a much smaller number $(\mathrm{N}=581)$ of primates, mostly guenons (Cercopithecus spp.), were exported for purposes of commercial trade, and almost all were wild-caught. ( $V$. Nijman, unpublished data based on CITES trade data). However, there appear to be wide discrepancies between the numbers reported by the importing countries $(\mathrm{N}=561)$ and the numbers reported as exported by DRC $(\mathrm{N}=347)$ (other items, such as skin, bones, "specimens" total 16,202 reported by importers; DRC reported 5,364 exports over the same period). In contrast, the live primate trade out of Madagascar and Brazil appears to be better controlled, with only 24 to 51 individuals, bodies and skins reported. All primates exported from Madagascar were wild-caught (Table 3).

In general, the illegal trade in primates is for pets, meat, and medicinal or mystical purposes. In Brazil, legal international trade in live primates appears to be limited (Svensson et al., 2016). However, surveys of animal markets in Brazil and in the tri-country border of Peru-ColombiaBrazil showed that capuchin and brown woolly monkey (Lagothrix lagothricha) body parts were important trade items (Ferreira et al., 2013; Van Vliet et al. 2014) (Text S1). The pet trade in primates in Indonesia occurs openly in dozens of markets, and is prevalent in Sumatra, Java, and Bali, as well as in Indonesian Borneo and on Sulawesi. For example, during 66 visits to bird markets in North Sumatra, 10 species of primates totaling 1953 individuals were available for sale (Shepherd, 2010). Some 1,300 primates were recorded during 51 surveys to six markets on Java and Bali (Nijman et al., 2017). This included individuals of eight species. The most common primates traded were macaques and the greater slow loris (Nycticebus coucang, Text S1). Slow lorises are locally traded for medicinal purposes throughout Indonesia (Nekaris et al., 2010) (Text S1). In Madagascar, a study reported the presence of $\sim 30,000$ pet lemurs of at least 16 species over a three-year period (Reuter et al., 2016).

\section{Harvesting (capture and killing) to extinction}

Range contraction, combined with unsustainable bushmeat hunting and capture for the trade of selected species, suggests that high prices for rare or difficult to acquire species can, over time, drive even large populations to local extirpation. The Anthropogenic Allee Effect (AAE) (Courchamp et al., 2006) proposes that such extinctions are caused when prices for wildlife products increase with species rarity and that this price-rarity relationship creates financial incentives to extract the last remaining individuals of a population, despite higher search and harvest costs (Holden \& McDonald-Madden, 2017). Another study suggests that while range contraction (habitat loss and fragmentation) causes population declines, local densities may remain relatively stable, especially in the case of animals like primates in which individuals can live for 20,30, or $>40$ years, facilitating harvesting to extinction of selected species (Burgess et al., 2017). The authors also showed that opportunistic exploitation, where harvesters hunt or 
522 capture rare species while chasing target species, can significantly reduce population number.

523 Clearly, current and predicted range contraction and abundance declines increase the extinction

524

525

526

527

528

529

530

531

532

533

534

535

536

537

538

539

540

541

542

543

544

545

546

547

548

549

550

551

552

553

554

555

556

557

558

559

560

561

562

563

564

565

566

567

risk to harvested primate species in the four countries. This deserves greater consideration in research, conservation management, and protection plans.

\section{Other emerging threats}

\section{Infectious diseases}

Across anthropogenically impacted landscapes, the threat to primates of exposure to emerging infectious diseases resulting from increased contact with human and domesticated animals or periodic epizootic outbreaks across a broad region can result in local primate population declines or extirpations from otherwise suitable habitat (Nunn \& Altizer, 2006; Nunn \& Gillespie, 2016). Between October 2002 and January 2004, outbreaks of EVD (Ebola Virus Disease) killed over $90 \%$ of the western gorillas (Gorilla gorilla) and possibly $80 \%$ of chimpanzees inhabiting the Lossi Sanctuary in northwest Republic of Congo (Bermejo et al., 2006). To date, however, there has not been an Ebola outbreak associated with any species of wildlife in DRC (Pigott et al 2014; 2016). Developing vaccines that can be administered safely and effectively to free-ranging populations of great apes may help mitigate the impact of EVD outbreaks although this would be extremely challenging since these primates are hunted and hence are not habituated to humans (Leendertz et al., 2016). In most cases, these vaccines are not yet available even to local human populations, which presents an ethical dilemma regarding whether or not to provide these vaccines to endangered apes. In Brazil, $80 \%$ of isolated populations of black-and-gold (Alouatta caraya) and brown (Alouatta guariba clamitans) howler monkeys in two areas in the state of Rio Grande do Sul were lost after a Yellow Fever (YF) epizootic event in 2008 and 2009 (Freitas \& Bicca-Marques, 2011; Veiga et al. 2014), including populations inhabiting protected areas (Fialho et al., 2012). Since 2016, an ongoing YF outbreak in Southeast Brazil has caused the death of thousands of primates, including threatened species such as the northern masked titi monkey (Callicebus personatus) and the brown howler monkey. In many instances, misinformation regarding vectors of YF disease transmission has resulted in members of the local human population exterminating nearby monkey populations (Bicca-Marques et al., 2017) (Text S1).

Susceptible primate populations inhabiting protected areas also are vulnerable to the introduction of exotic (non-native or alien) pathogenic agents into the naïve population, a process known as pathogen pollution (Daszak, Cunningham \& Hyatt, 2000). The death of introduced marmosets (Callithrix spp.) infected with human herpesvirus 1 in a Brazilian nature reserve illustrates how proximity to humans can risk the survival of wild primate populations (Longa et al., 2011). The risk of epizootic disease transmission is particularly serious for those primates living near or within regions inhabited by dense human populations, such as in most of Indonesia, where Streptococcus equi caused high mortality among long-tailed macaques in 1994 (Soedarmanto et al., 1996). In Indonesia, outbreaks of measles, rubella, and parainfluenza has affected the survivorship of long-tailed macaque $M$. fascicularis groups living in close contact with humans (Schillaci et al., 2006). In Madagascar, lemurs inhabiting forests near human settlements are exposed to pathogenic enterobacteria (Escherichia coli, Shigella spp., Salmonella enterica, Vibrio cholera and Yersinia spp.; Bublitz et al., 2015), protists (Cryptosporidium sp.; Rasambainarivo et al., 2013; Toxoplasmosis gondii) and viruses (Herpesvirus hominis and West Nile Flavivirus; Junge \& Sauther, 2006) found in humans, livestock, pets and peridomestic 
568

569

570

571

572

573

574

575

576

577

578

579

580

581

582

583

584

585

586

587

588

589

590

591

592

593

594

595

596

597

598

599

600

601

602

603

604

605

606

607

608

609

610

611

612

613

rodents. Likely or proven cases of transmission of human diseases to great apes include enterobacteria, human herpes simplex virus, a measles-like disease, a polio-like disease, respiratory diseases scabies (Gilardi et al. 2015).

\section{Climate change}

Evidence for the impact of local and global climate change on primate populations is limited. However, current assessments indicate the expected extremes in temperature and rainfall will put primates at significant risk (see Fig. 2 of Graham et al., 2016). Climate change projections suggest that Brazil`s four endemic species of Atlantic forest lion tamarins (Leontopithecus spp.) will experience major shifts and/or reductions in habitat suitability in the coming decades (Meyer, Pie \& Passos, 2014). Similarly, the distribution of the northern muriqui (Brachyteles hypoxanthus) is expected to be reduced by more than half of its original area, with a large decline in the future suitability of currently protected reserves due to climate change (Melo et al., 2016). In Madagascar, in response to climate change most lemur species are expected to experience marked reductions in population number and distributions, even in the absence of future anthropogenic deforestation, with predicted declines of $\sim 60 \%$ for lemurs' habitats (Brown and Yoder, 2015).

Climate change will likely increase primate exposure to potentially harmful human-borne parasites, triggered, for example, by increases in temperature and rainfall leading to faster parasite reproduction or longer periods of parasite transmissibility in primate rich regions (Barrett et al., 2013). Although certain species may be successful in shifting their range into newly created or expanded environments, this is likely to have negative consequences for other species that are displaced or out competed (Schloss, Nuñez \& Lawler, 2012). For example, forest fragmentation resulting from changing climates is expected to limit the availability of dispersal routes used by titis (Callicebus spp.) in eastern Brazil (Gouveia, et al., 2016). Moreover in the future, protected areas and parks created to sustain threatened species may no longer be suitable due to changes in vegetative cover in response to climate change, or individuals may migrate into neighboring and unprotected forests where they are exposed to hunters or local residents (Araújo et al. 2004,; Malhi et al., 2008; Struebig et al., 2015; Wiederholt \& Post, 2010). Projections of climate change in Central Africa are less clear (Abernethy et al., 2016). However, rainfall decline may occur, leading to a reduction in forest cover in DRC (Beyene et al., 2013); other work suggests the opposite may be true (Zelazowski et al., 2011). Regardless, clearing of additional forest for agriculture results in land desiccation which when combined with droughts and El Niño episodes result in extensive wildfires (Laurance et al., 2014; World Bank, 2017), impacting primate populations (Graham et al., 2016.) The most forceful example of this is human-made fires that resulted in the burning of 2.6 M ha of land in Indonesia between June and October of 2015. These fires were fed by drought and the effects of a prolonged El Niño. Degraded peatlands, most of them found in Sumatra, Kalimantan and Papua Province, Indonesia are particularly sensitive to fires that easily spread to adjacent forests. For example, the 2015 fires burned some $700 \mathrm{~K}$ ha of natural forest, swamp forest and forestry concessions plus $505.8 \mathrm{~K}$ ha of palm oil concessions (World Bank, 2017). Therefore, mitigating climate change impacts on the potential for mass fires is critical for primate survivorship in Indonesia.

\section{Human population \\ Trends and projections in human population growth}


614 Environmental pressures exerted by a growing human population are a major driver of primate 615 habitat and population decline in each country (Crist, Mora \& Engelman, 2017). In 2016, 616 Indonesia was the most populous of the four countries with slightly over 263 million people, 617 followed by Brazil (about 211 million), DRC (about 80 million) and Madagascar (about 26 618 million). Human population density is highest in Indonesia (145 people $/ \mathrm{km}^{2}$ ) and lowest in 619 Brazil (25 people $\left./ \mathrm{km}^{2}\right)$ (Table 4, Text S1). Population growth rates for 2016 were highest in $620 \mathrm{DRC}(3.09 \% / \mathrm{yr})$ and Madagascar (2.75\%/yr), lower in Indonesia (1.07\%/yr) and lowest in Brazil

621

622

623

624

625

626

627

628

629

630

631

632

633

634

635

636

637

638

639

640

641

642

643

644

645

646

647

648

649

650

651

652

653

654

655

656

657

658

659

$(0.77 \% / y r)$ (Table 4$)$. Human population projections for the year 2050 indicate continued growth in all four countries with DRC showing the steepest increase, followed by Madagascar, Indonesia, and Brazil. In Brazil and Indonesia, much of this population growth is expected to occur in urban areas (Fig. 5). And although in the short term rural populations are expected to expand rapidly in DRC and Madagascar, projections suggest that by 2050 their urban population (69\% of the population of DRC and 55\% of the population in Madagascar) will surpass their rural population (Fig. 5). The large size and projected increase of the population in all four countries in the first half of this century is expected to exponentially extend the human and urban footprint on primate habitats, near and beyond cities. These negative impacts will result from increasing demands for energy, space, food, water, minerals, oil, construction material, forest products, and transportation, as well as from environmental damage caused by pollution and by the expansion of road and rail networks to satisfy food and non-food urban needs (Estrada 2013; Estrada et al., 2017). And, although cities concentrate poverty, they also are places of innovation, knowledge, technical expertise, and leadership (van Ginkel, 2008) offering important decision-making tools for primate conservation. For example, green (environmentally friendly) policy initiatives such as recycling, desalination and water treatment, a commitment to re-useable energy, and others can limit a cities ecological footprint (Butler \& Laurance, 2008). These policy changes offer the opportunity for these four countries to take advantage of the movement of people from rural to urban areas to reinvest in forest recovery and habitat restoration in these newly vacant spaces (Ashraf et al., 2016), and thereby promote conservation policies favouring primate population recovery and expansion.

\section{Socioeconomic indicators and human development Gross Domestic Product per Capita (GDPPC)}

Effective and long-term primate conservation requires economic resources, adequate conservation policies, effective law enforcement, conservation-oriented research and public interest. If high levels of poverty are predominant, country-wide primate conservation will be a low national priority. The 2015 GDPPC of Brazil, Madagascar, Indonesia and DRC, was, on average, lower than the world's average $(\$ 10,130)$ and significantly lower than the average GDPPC for the top 25 most developed nations $(\$ 57,509)$. Among the four countries, DRC and Madagascar have the lowest 2015 GDPPC values (\$452 and \$402, respectively; Indonesia $\$ 3,346$; Brazil \$8,678) (Table S5). Changes in the GDPPC from 1990 to 2015 for these four primate-richest countries indicate major gains for Indonesia and Brazil whereas the GDPPC has remained very low in DRC and Madagascar (Fig. 6). This is consistent with levels of child malnutrition. The percent of children who are underweight in Brazil is 3.7\% (2002), in Indonesia 19.9\% (2013), in DRC 23.4\% (2013) and in Madagascar 36.8\% (2004). In contrast the values for high income countries is $0.9 \%$ (2016) (The World Bank, 2017).

\section{Human Development}


660 The 2015 UN Human Development Index (HDI; a combination of life expectancy, school 661 enrollment, literacy, and income, with the Lowest human development $=0$; Highest $=1.0$; 662 UNDP, 2016) indicates that DRC and Madagascar have the lowest values among the four 663 countries, while the HDI values for Brazil and Indonesia approach the world's average (Fig. 7).

664 In general, the HDI increased in all four countries from 1990 to 2015, but while the HDI increase 665 in Brazil and Indonesia paralleled increases in the world's average, human development 666 remained relatively stagnant for Madagascar and DRC (Fig. 7). Values of the HDI for these four 667 countries are, nonetheless, quite low compared to those highest ranking 25 countries worldwide 668 (Fig. 7, Table S5). Low levels of HDI are commonly associated with political instability, extreme income inequality, and limited environmental protection (Alsamawi et al., 2014; Neumayer, 2017). While these four primate-rich countries have much to achieve in human development compared to the top 25 developed nations, it also is clear that the economic standing and human development of Brazil and Indonesia are following a trajectory that is different from that of DRC and Madagascar (Fig. 7). These latter two countries face more serious challenges in securing resources for their human population and for primate conservation.

677 Civil unrest and conflict also affect primate survivorship due to indiscriminate bombing, the spread of toxic chemicals (Douglas \& Alie, 2014; Loucks et al., 2009), increases in the availability of firearms, and the increase in bushmeat hunting by soldiers and displaced civilians. Poaching of many primates including grey-cheeked mangabeys (Lophocebus albigena), bonobos and Grauer's gorillas, for example, has increased markedly in DRC because of ongoing civil wars (Douglas \& Alie 2014; IUCN \& ICCN 2014; McNeely, 2003; Plumptre et al., $2016 a$ ). Landmines, the legacy of wars in the 1960's, 1970's, and 1990's, and numerous militia groups continue to jeopardize monkeys and apes in DRC, where civil conflict has interrupted wildlife protection by guards in national parks (e.g., Virunga; Kalpers et al., 2003; McNeely, 2003). Currently, heavily armed militias in the Kasai, North Kivu and South Kivu in DRC fight for ethnic and political control and, together with illegal miners, prospect for "conflict minerals" (e.g., coltan, tin, tantalum, tungsten, and gold) and diamonds, and hunt primates as bushmeat (Gavin, 2017; Nelleman, Redmond, Refisch, 2010). Similarly, border conflicts between Indonesia and Malaysia on the island of Borneo have caused damage to the forest and wildlife. In the 1990s, however, business and military leaders colluded to suspend conflict in order to cut down and burn millions of hectares of forest to plant cash crops (McNeely, 2003), impacting the survival of entire primate communities. Civil conflict also alters land use patterns and can lead to increased unregulated forest conversion. In the north Sumatran region of Aceh, for example, human conflicts combined with forest fires and legal and illegal logging led to a reduction in forest cover of greater than 30\% from 1990 to 2010 (Margono et al., 2012). Disputes over land rights, private corporate actions, and governmental regulations also have led to forest burning and land-clearing across the island of Sumatra, directly threatening the Sumatran langur, banded langur ( $P$. femoralis), and Thomas's langur ( $P$. thomasi), as well as Bornean orangutans and Müller's gibbons in Indonesian Borneo (Lanjouw, 2014; Meijaard \& Nijman, 2000; Supriatna et al., 2017).

Civil unrest, inter-country wars and continued militarization contribute to the displacement of the local human population, increasing poverty, social insecurity, and environmental damage. The 2017 Global Peace Index (GPI; http://economicsandpeace.org_), which measures ongoing 
706

707

708

709

710

711

712

713

714

715

716

717

718

719

720

721

722

723

724

725

726

727

728

729

730

731

732

733

734

735

736

737

738

739

740

741

742

743

744

745

746

747

748

749

750

domestic and international conflict (ODIC), societal safety and security (SSS) and militarization (MILIT) (IEP, 2017) rank DRC as having the highest values among the four countries (Table 5). Madagascar and Indonesia have lower GPI values for all three insecurity measures, and Brazil has a low value for just one measure ODIC). When a country's economic, political and human resources are drained to deal with ongoing civil and ethnic conflicts and societal safety, primate conservation is not a priority. Insecurity and lack of personal safety in these countries are enhanced by prevailing corruption and low-quality governance (see below).

\section{Corruption, governance quality and primate conservation}

Corruption is a major threat to primates because it distorts environmental laws, giving way to deforestation and land speculation and promoting poverty and illegal activities, including mining, poaching, logging, and the primate trade. Corruption and inequality interact by generating a vicious circle of greed, the unequal distribution of power in society, and the unequal distribution of wealth. The 2016 Transparency International Corruption Perceptions Index (0: highly corrupt to 100: very clean) profiling 176 countries (CPI, 2016) places Brazil with a score of 40 (rank 79), Indonesia a score 37 (rank 90), Madagascar a score 26 (rank 145), and DRC with a score of 21 (rank 156), consistent with the high levels of corruption present in all four countries, but especially in Madagascar, DRC (CPI, 2016), and most recently in Brazil.

Corruption hampers efforts directed at wildlife conservation and weakens protected area capacity to prevent drivers of primate habitat loss and local species extirpation (see Text S1 for the case of Brazil). In the four countries laws are often skirted or ignored through bribery and extortion. For example, trading orangutans in Indonesia is a crime but 440 confiscations in the last 25 years have led to only seven convictions and sentencing was lenient (Nijman, 2017). DRC has a patronage system in which the profits of "unofficial economic activities" or "predation" flow upwards to the top of the chain of command hampering the way forward with environmental issues (Baaz \& Olssen, 2011: see Text 1). In Madagascar, illegal exploitation and export of rosewood in protected areas, with associated negative effects on wildlife populations, has been facilitated by political instability and corruption (Randriamalala \& Liu, 2010). Complicity between businesses and politicians had led to the theft of billions of dollars in revenue from national economies, benefitting the very few at the expense of the many and preventing sustainable development (Baaz \& Olsson, 2011; CPI, 2016). Profiling four key World Bank indicators of governance quality in 2016 indicates that these primate-richest countries all rank significantly lower than the average values for 35 high-income countries (Fig. 8). Overall, weak governance appears to be characteristic of these four countries, with DRC (coded in the World Bank database as Congo Dem. Rep.) and Madagascar ranking lowest (see Freudenberger 2010). Given high levels of corruption and prevalent low human development, country-wide conservation of primate habitats and populations in these four countries remains a complex challenge. Moreover, measurements of the effectiveness of governance require a thorough causal analysis (with counterfactuals) to determine the degree to which the current status of individual primate species is best attributed to good policies that are poorly implemented, the continuation of ineffective policies, or the result of strong and effectively managed policies (see Baylis et al., 2016)

\section{Landscape approaches to primate conservation Protected areas}


751 Protected areas represent an effective conservation tool in which local, state and national

752 governments can act to protect ecosystems and provide resources to conserve animal

753 populations, provided that these areas also contribute to alleviate rural poverty (Adams \& Hutton,

754 2017). An Africa-wide assessment of which factors were most effective in maintaining great ape

755 populations concluded, after examining 120 areas, that effective law enforcement was the most

756 important (Tranquilli et al., 2012) followed by long-term conservation NGO involvement.

757 Similarly, a recent rangewide assessment of the two great ape taxa in Western Equatorial Africa

758 shows that the presence of wildlife guards was one of the most effective predictors of great ape

759 density (Strindberg et al., 2018), and that intact forest and low human pressure metrics were also

760 key - both of which are generally characteristic of the protected areas and selectively-logged

761 Forest Stewardship Council (FSC)-certified concessions of Central Africa. Globally, protected

762 area networks are located in ecological zones that have low value and low demand for land

763 conversion, are inexpensive to protect, and, some, but by no means all, are, located far from

764 areas of high biodiversity (Joppa \& Pfaff, 2009). As a result, this discrepancy or this mode of

765 selection has placed primate-rich lowland forests at risk because lowland forests offer profitable

766 opportunities to obtain land wel-suited to industrial agriculture (Venter et al., 2014) or clear-

767 cutting for timber. In this regard, governments need to partner with the scientific community and

768 the expertise of local, regional, national and international NGOs to design extensive networks of

769 protected areas and private reserves that have as their goal the creation of ecological zones and

770 land use policies that collectively sustain both biodiversity and human communities (Hill et al.,

771 2015). There is evidence that protected areas provide sustainable core habitat for primates. They

772 represent a keystone tool for the conservation of threatened primates in Brazil's Atlantic forest.

773 For example, almost $80 \%$ of the total localities of Atlantic Forest where muriquis (Brachyteles

774 spp.) presently inhabit are protected areas (private or governmental - state and federal units,

775 Strier et al., 2017). In Central Africa, a long-term study (2007-2014) in which camera traps were

776 used to census terrestrial mammals found strong evidence of stability in several threatened

777 African primates such as the l'Hoest's monkey, mandrills (Mandrillus sphinx) and chimpanzees

778 (Beaudrot et al., 2016).

779

780

Conservation efforts targeted to deliberately increase positive human influences, including

781

782

783

784

785

786

787

788

789

790

791

792

793

794

795

796 veterinary care and close monitoring of individual animals succeeded in doubling the Virunga mountain gorilla population over 40 years (Robbins et al., 2011). These gorillas occur in protected areas, including in DRC. Protected areas are effective in minimizing population decline as has been reported for the pale-thighed langur (Presbytis siamensis) in Sumatra and the redfronted brown lemur (Eulemur rufifrons) in Madagascar (Beaudrot et al., 2016). From 1990 to 2000, protected areas in Sumatra experienced lower deforestation rates than nearby unprotected areas (Gaveau et al., 2009; Gaveau, Wich \& Marshall, 2016). In Zanzibar, Tanzania, mean group sizes of the Zanzibar red colobus Piliocolobus kirkii were significantly higher in protected areas (21 individuals) than outside protected areas (13 individuals). Clearly, individuals outside of protected areas are at greatest risk (Davenport et al., 2017). In this regard, Brazil has 29\% of its land under protection, DRC 13\%, Madagascar 12\%, and Indonesia 12\% (Table 6; see Text S1 for additional information).

\section{Assessing the overlap between protected areas and primate distributions}

Modeling the distribution of protected areas and primate distributions in the four countries showed that, on average, primates in Brazil have 38\% of their range included within protected 
797

798

799

800

801

802

803

804

805

806

807

808

809

810

811

812

813

814

815

816

817

818

819

820

821

822

823

824

825

826

827

828

829

830

831

832

833

834

835

836

837

838

839

840

841

842

843 areas; $38 \%$ in Madagascar, $17 \%$ in Indonesia and 14\% in DRC, suggesting that the great majority of primate populations exist outside of protected areas (Fig. 9, Fig. S7; see Strindberg et al., 2018 for the case of central African chimpanzees and western lowland gorillas in Western Equatorial Africa where $80 \%$ of both primates occur outside of protected areas). Regrettably, the distribution of protected areas in each of the four countries is extremely patchy, and in many cases subpopulations of the same species are isolated from each other and inhabit areas that are experiencing considerable deforestation and fragmentation as they are increasingly impacted by agricultural expansion, logging and illegal hunting as well as an ever-growing urban footprint (Fig. 3, Fig. 9) (Mascia et al., 2014; Rovero et al., 2015; Spracklen et al., 2015). Due to illegal activity in the Brazilian Amazon, natural resource reduction is pervasive. Most transgressions were related to habitat degradation (37\%), illegal fishing (27\%) and the game hunting (18\%) (Kauano, Silva \& Michalskil, 2017). Increasing human population density within $50 \mathrm{~km}$ of a protected area is a crucial factor that promotes illegal activities. Meeting global goals for protected-area coverage will be insufficient to protect biodiversity unless these areas are well managed and properly located (Butchart et al., 2015). Analysis of the distribution of protected areas and primate distributions is critical for diagnosing areas in need of protection. For example, whereas $22 \%$ of the distribution of the Bornean orangutan is in protected areas and $29 \%$ occurs in forest concessions, the remaining $49 \%$ is in unprotected and commercially developed forests (Wich et al., 2012). A similar pattern emerged in an earlier analysis of all primate species in Indonesian Borneo (Meijaard \& Nijman, 2003).

\section{Community forest management (CFM), habitat restoration and landscape connectivity} Community forest management (CFM) aims to reduce deforestation and maintain biodiversity while also improving local human welfare (alleviate poverty). In general, there is evidence of CFM being associated with greater tree density and basal area (Bowler et al., 2012). A review of 33 community forests (all but one in Latin America, the other in India) showed that a commitment to land-sharing (combining forms of agroforestry along with forest managed by local communities in which resources are extracted sustainably) can lead to reduced rates of deforestation compared to protected forests (Porter-Bolland et al., 2012). In another study of CFM certification of timber, based on 318 comparisons from 50 studies distributed across Africa, Asia and South and Central America, CFM performed better than open access areas in $56 \%$ of 185 comparisons, equally in $25 \%$ and worse in $19 \%$ (comparisons focused on economic, social and environmental variables) (Burivalova et al., 2017). Similarly, a nation-wide survey in Madagascar of CFM impacts on household living standards (as measured by per capita consumption expenditures) showed that well-being was stronger for households closer to forests and households with more years of education (Rasolofoson et al., 2017). In another study in Madagascar, CMF was shown to reduce deforestation in CFM localities that do not permit commercial uses of wood compared to areas that lack CFM or in CFM areas that allow commercial uses (Rasolofoson et al., 2015). In Indonesia, the total area of CFM forests (Hutan Desa, or village forest, is an approach that stresses local village governance and autonomy in forest protection and in controlling resource extraction by outside groups) increased from $750 \mathrm{~km}^{2}$ in 2012 to $2500 \mathrm{~km}^{2}$ in 2016 . A spatial matching approach showed that under a Hutan Desa management scheme, deforestation was avoided compared to the expected likelihood of deforestation in the absence of Hutan Desa management (Santika et al., 2017b).

Forests are one of the few resources accessible to local communities in primate range countries, and participating in their ownership, stewardship, and restoration can provide food, economic 
844 opportunity, and income to poor people (Porter-Bolland et al., 2012). Reforestation is an 845 important conservation tool to help both rural communities and to mitigate species extinction due 846 to habitat loss, fragmentation, and isolation, especially if it involves protecting large forest areas 847 (Taubert et al., 2018). An expansion in available habitat via restoration can facilitate an increase 848 in species' population size and connect fragments and protected areas, if strategically located 849 restored forest can promote immigration and gene flow from previously isolated but now source 850 populations (Hylander, 2013). Targeting habitat restoration to areas of once contiguous forest using corridors 1-km wide between the most extensive, intact, and closest forest fragments can have a positive effect on wildlife population expansion (Newark et al., 2017). A study in the Atlantic Forest of Brazil that modeled the use of forest corridors as a conservation tool found that regenerating corridors totaling $6.4 \mathrm{~K}$ ha would result in an continuous forested area measuring $251.9 \mathrm{~K}$ ha. Although full regeneration of these corridors is likely to take 10 to 40 years (Newmark et al. 2017), extinction-prone primate species such as golden lion tamarins (Leontopithecus rosalia) and golden-headed lion tamarins (Leontopithecus chrysomelas) can disperse through linked forests that are $<10$ years old (Dosen, Raboy \& Fortib, 2017; Newmark et al. 2017). Landscape connectivity also can include community managed forests in which agroecosystems such as shade-grown coffee (Coffea spp.), cacao (Theobroma cacao), and cardamom (Elettaria cardamomum), as well as small shaded mixed plantations of natural rubber (Hevea brasiliensis) and oil palm, among other arboreal crops, provide income for farmers and temporary habitat, food resources, and dispersal routes for isolated segments of primate subpopulations (Estrada, Raboy \& Oliveira, 2012; McLennan, Spagnoletti \& Hockings, 2017). Still, the persistence of primates in agroecosystems in Brazil, Madagascar, Indonesia and DRC

\section{Primate rewilding}

Where primate species are locally extirpated, reintroductions may be a feasible conservation strategy if there is long-term protection of forests and monitoring of population changes (Baker, 2002; Beck et al., 2007; Wilson et al., 2014). In general, guidelines for most species, including great apes, underline the importance of ensuring that the threat that caused the animals to become locally extinct (such as poaching) has ceased before attempting reintroduction (Beck et al., 2007, IUCN/SSG, 2013). Reintroduction and translocation programs also serve to intensify public interest on conservation issues, especially when combined with social media (Kierulff et al., 2012). Reintroduced primates include orangutans and slow lorises in Indonesia (Moore et al., 2014; Wilson et al.,2014), and golden lion tamarins, pygmy marmosets (Cebuella pygmaea) and northern muriquis in Brazil (Car, Queirogas \& Pedersoli, 2015; Kierulff et al., 2001; Melo, 2016). Some of these releases, e.g. golden lion tamarins, led to the establishment of selfsustaining populations, whereas in others, for example, Javan slow lorises (Nycticebus javanicus), high mortality in the first few months, questions the viability of these programs (Moore et al., 2014). In Madagascar, there have been reintroductions and translocations of captive-born and wild-born lemurs (Schwitzer, 2013). This has resulted in successful population establishment in the cases of released aye-ayes (Daubentonia madagascariensis), captive-bred black-and-white ruffed and collared-brown lemurs (Eulemur collaris), but in several instances, there was high mortality due to natural predation (Britt, Welch \& Katz, 2004; Donati et al., 2007; Mittermeier et al., 2010). In contrast, the translocation of black-and-white ruffed lemurs and diademed sifakas from forests from a forest selected for clearing by a mining company to the nearby Analamazaotra Special Reserve (ASR), was successful (Day et al., 2009). After several 
890

891

892

893

894

895

896

897

898

899

900

901

902

903

904

905

906

907

908

909

910

911

912

913

914

915

916

917

918

919

920

921

922

923

924

925

926

927

928

929

930

931

932

933

934

years of rehabilitation, bonobos rescued from the illegal trade also have been successfully reintroduced in the "Ekolo Ya Bonobo" release site in DRC

(http://www.lolayabonobo.org/ekolo-ya-bonobo; accessed 30th November 2017). Nevertheless, extreme caution must be taken in evaluating areas for reintroduction, as in many cases humans and primates favor the same ecological zones, and primates may face severe competition from human, as is the case for the Bornean orangutan (Santika et al., 2017a) and the population of black-and-white ruffed lemur currently living in the ASR (Rasoamanarivo et al., 2015). These two studies may guide future attempts (Text S1). Finally, reintroductions are costly relative to other options (e.g. long-term protection of forested land) and therefore are often best used as a last resort (Wilson et al., 2014).

\section{Socially-oriented conservation actions for averting local extinction threats to primates}

The development of community-based local education programs, action groups, and NGOs/Associations that focus on primate conservation initiatives are key instruments that can successfully result in local and long-term conservation of primate species. The involvement of NGOs (International Committees for Conservation and Management - ICCM and the ProMuriqui Institute (Text S1) has been crucial in Brazil for the conservation of threatened species such as the golden lion tamarin and the muriqui (Text S1). The Critically Endangered Javan slow loris is one of the focal species of the Little Fireface Project (http://www.nocturama.org). Implemented in 2011, this project has involved a wide range of audiences and stakeholders, providing annual training sessions for law enforcement officers and coordinated biannual events in villages close to where wild slow lorises occur, to increase protection and pride in this endemic species. A population of these slow lorises has been monitored on Mt Papandayan, West Java, for seven years, revealing vital information on their biology and conservation (Nekaris, 2016; Nekaris et al., 2018; Text S1). In DRC, international conservation NGOs are working in and around most conservation landscapes, with coordination offices in the capital; some of these NGOs have been working in DRC for over 30 years. NGOs support the wildlife authority of the ICCN (Congolese Institute for Nature Conservation), and provide technical assistance (training, equipment) to government antipoaching patrols, that plays a critical conservation role inside national parks, including the development of a system for rapid collection of both patrol and survey data in the field (SMART, http://smartconservationtools.org/) (Text S1).

Literacy is another critical factor in developing effective conservation education programs (Clayton \& Myers, 2009; Oboh \& Tsue, 2010). Youth (15-24 years) literacy rates are 76.8\% (2012 data) in Madagascar, 85.0\% in the DRC (2016), 98.8\% in Brazil (2014) and 99.7\% in Indonesia (2016) (http://data.uis.unesco.org/\#). In addition, in rural parts of DRC and Madagascar, adult literacy is some $25 \%$ lower than in urban populations (UNESCO, 2006). Educational programs targeted at less literate populations are more effective when environmental messages are presented using simply written phrases, radio and television programs, music, images, live performances, and other non-written forms of communication.

In Madagascar, the NGO Reniala acts to protect forests, rehabilitate lemurs from the pet trade, provide incentives to discourage hunting, and has developed alternative livelihood projects for local residents, such as beekeeping (https://association-reniala.jimdo.com/). Centre Valbio is a research center with an integrated conservation program, that works directly with the Malagasy 
935

936

937

938

939

940

941

942

943

944

945

946

947

948

949

950

951

952

953

954

955

956

957

958

959

960

961

962

963

964

965

966

967

968

969

970

971

972

973

974

975

976

977

978

979

980

government in the Ranomafana National Park - 41,500 hectares of rainforest that includes the golden bamboo lemur (Hapalemur aureus), discovered at this site in 1986

(http://www.stonybrook.edu/commcms/centre-valbio/conservation.html). The Maromizaha forest Conservation and Community Project in Madagascar protects a large forest tract with 13 species of lemurs, using forest-friendly alternative agricultural practices and promoting the development of ecotourism (Gamba et al., 2013). Because of the recent growth in trained primatologists in the four countries, their conservation concerns have led to the creation of professional societies that can more effectively articulate conservation concerns with local governments, NGOs, rural communities and international societies (Text 1). In Madagascar, conservation education, especially of young children, also has made important strides in protecting primates (Dolins et al, 2010).

\section{Conclusions and key challenges ahead}

Primate conservation is a global, multilayered, biological, ecological and social issue. There are over 500 primate species in the wild and these taxa differ in ecological requirements, behavioral flexibility, reproductive capacity, social systems, and are long-lived (Fig. 10). As a result, their responses to conservation initiatives are often difficult to assess in both the short and long term. There is no single blueprint or best course of action for advancing primate conservation in Brazil, Madagascar, Indonesia and DRC. Each country differs in its history, societal and economic needs, and current environmental and governmental policies that are driving primate habitat loss and population decline. These four countries face unprecedented environmental and social challenges in implementing effective primate conservation (Fig. 11). They have rapidly growing human populations and low human development indices compared with more developed nations. Each has also experienced large-scale losses of native vegetation and other natural resources plus high levels of corruption and weak governance. Each country's desire to move its economy forward to meet the needs of its population remains a priority but this seems difficult to achieve in a global system in which international trade led by the demands for food and non-food products by a small set of developed and consumer nations distract attention from the needs of their local populations. Despite significant increases in revenues derived from agricultural exports in these four countries, millions of their citizens remain undernourished, undereducated, and poor (World Bank, 2017). While Brazil has made important strides in reducing deforestation, decreasing poverty, and fostering science and education with direct positive impacts on primate conservation, a change in government policies in 2012 reduced the protection of natural vegetation on private lands (Brancalion et al., 2016) and laws governing protected areas were reduced and weakened (Bernard et al., 2016). Funding for science also was reduced (Overberch et al., 2018). This has resulted in a sharp increase in deforestation rates (Fig. 2), with expected negative effects on biodiversity, primates, people's livelihood's and conservation.

Given the rapid pace and large scale at which native forests have been cleared in Latin America and Indonesia to expand agriculture to satisfy global and local demands (Tilman et al., 2017), critically evaluated approaches are needed to ensure primate survival. For example, it is argued that promoting "sustainable intensification" of agriculture on already cleared lands could readily supply production that might otherwise be expected to come at the cost of future land conversion (Carlson et al., 2018). This requires linking smallholders (farmers) with commercial

international agriculture (Goldsmith \& Cohn, 2017). This, however, does not mitigate the already 
981 high environmental costs of cleared land. Moreover, global dietary changes, promoted in large 982 part by multinational businesses and designed to expand corporate profit margins, will require 983 these primate-rich countries to convert additional forested land into monocultures (Kastner et al.

984 2012; Tilman \& Clark 2014). This is likely to happen more slowly in DRC, as civil war, political instability, governance issues and continued poverty (according to the internationally recognized metrics used by the World Bank / UNDP) limit international investment (Kastner et al. 2012). Bsed on a range of global factors, agribusiness corporations may switch to different crops and land-use patterns to maximize profit or may increase or decrease investments in other countries leading to increased environmental damage and poverty (Carrasco et al., 2014; Lim et al., 2016; Villoria et al., 2013; Weng et al., 2013). Intensification of agriculture to increase yields does not necessarily contribute to global hunger reduction, as an unequal amount of food and nonfood products are used by already well-fed people in a small number of consumer nations. Rather, food security needs to increase in areas of the world where the hungry live using eco-efficient approaches that encourage sustainable productivity and incorporates natural biodiversity, and clean and reusable forms of energy, while sustaining multiple ecosystem services (Keating et al., 2010). Using an eco-friendly approach, agriculture practiced by small landholders and sensitive to local markets and conditions rather than large-scale industrial farming, is the key to food security in the developing world (Tscharntke et al., 2012).

Clearly, additional research is needed to examine the role of local and global market demands on primate conservation (Larrosa, Carrasco \& Milner-Gulland, 2016), including studies to evaluate the extent to which the reduction of land for purposes of agricultural conversion benefits the local human and nonhuman primate communities. Within this framework, economic instruments targeted to consumer nations such as taxes on agricultural inputs and taxes on consumption as well as investment in sustainable agri-environmental production that guarantees the persistence of multiple ecosystem services may be, in some countries, viable alternatives to mitigate the negative impacts of agricultural expansion (Nepstad et al., 2014; Tanenzap et al., 2015).

Worldwide, policies targeting consumer nations that reduce their ecological footprint in primate range regions are needed. Green tagging and certification, greater controls on fair trade, corporate responsibility in recycling, and pollution and carbon emmisions control, the elimination of excessive packaging, and the sustainable purchasing of goods and services are critical tools for lowering worldwide demand for processed materials (Moran, Petersone \& Verones, 2016) and would help alleviate pressures on primate habitats (Dalerum, 2014). As part of the 'greening' of trade, international corporations should add 'environmental' costs to products so that there is a continuous regeneration of funds to sustainably promote conservation (Butler \& Laurance, 2008). Alternatively, the World Bank or UN could require that corporations and consumer nations pay into a sustainability/conservation fund based on their levels of consumption and environmental damage (e.g., like a carbon tax; Carbon Tax Center https://www.carbontax.org; consulted August 2017). In countries in which the rural poor depend on forest products, community forest management could bridge or integrate the needs of conservation and commodity production, sustainably safeguarding the continued integrity of complex ecological systems (Sharif \& Saha, 2017). The recent environmentally-oriented, demand-side policies regarding illegal timber imports by the EU (EU, 2010), the EU resolution on oil palm production and deforestation $(E P, 2017)$, and the Amsterdam Declaration to eliminate deforestation from agricultural commodity chains (Amsterdam, 2015) represent 
1027 important and positive 'green' changes that need to be adopted by the U.S., China, and other 1028 consume nations. However, the continued growth of the global demand for forest-risk

1029

1030

1031

1032

1033

1034

1035

1036

1037

1038

1039

1040

1041

1042

1043

1044

1045

1046

1047

1048

1049

1050

1051

1052

1053

1054

1055

1056

1057

1058

1059

1060

1061

1062

1063

1064

1065

1066

1067

1068

1069

1070

1071

1072 agricultural and nonfood commodities requires additional legislation and a stronger global effort at regulating the negative impact of unsustainable commodity trade (Henders et al., 2018).

In the context of large-scale deforestation, Brazil, Madagascar, Indonesia, and DRC face additional challenges that require cost-effective policies designed to maintain intact areas of forest and biodiversity (Busch \& Engelmann, 2018) (Fig. 11). One approach to achieve this goal is the REDD+ program where funds are provided by consumer nations to forest-rich countries to offset emissions from deforestation, forest fragmentation, and other forms of environmental degradation (Venter \& Koh, 2012). These funds could be targeted to expand forested habitats and connect forest fragments, as well as provide security for local populations by increasing the economic and ecological value of maintaining forested land. These programs are just beginning but are showing some promising results in DRC (Fobissie, 2015), in Makira, Madagascar (see. https://madagascar.wcs.org/Makira-Carbon.aspx) and in the Atlantic Forest of Brazil (Brancalion et al., 2013).

The forecasted future human population and economic growth of Brazil, Indonesia, DRC, and Madagascar along with increased global and local demands for food and non-food products will heighten pressures on primate populations in these four countries. The Brazilian ability to combat deforestation by $80 \%$ between 2005 and 2013 is an example that could be followed by the other three countries (Dobrovolski \& Rattis, 2014: Nepstad et al., 2014). Countries that rely on agricultural and natural resource exports from these four primate-rich countries must become major contributors to conservation efforts that take place beyond their borders. The safeguarding of the primate fauna in each country will require an increase in suitable land devoted to protected areas and improved conservation management, as many species lack adequate protection (Jорра et al., 2009). In addition, given that the unprecedented globalized demand for illegal wildlife, the bushmeat trade, and the use of body part in traditional medicine and as trophies, is rapidly depleting natural primate populations (UNODC, 2016), an international agency, such as Interpol, that has the capacity to conduct and coordinate counter intelligence investigations worldwide is critically needed. These international investigations can identify criminal organizations involved in the illegal trade, which should be considered a form of bioterrorism (Fig. 4, Fig. 11). Given the severity of this problem, stopping the supply chain of illegal primate hunting and primate trade in the four countries needs to be included in integrated conservation models (Brashares et al., 2014) that also addresses government corruption (Estrada et al., 2017). This also requires a focused effort to promote a positive attitude, both in primate range countries and in consumer nations towards environmental protection and conservation education, and interventions need to provide resources and access to information to encourage members of local communities to protect wildlife (Challender and MacMillan, 2014).

Our review has shown that local and global social, economic and political factors imperil the persistence of primate populations in Brazil, Madagascar, Indonesia and DRC, and that more needs to be done by local governments and international bodies to ensure that primates, a critical component of each nation's natural heritage and biodiversity, do not become rare, locally extirpated, or in the case of endemic species, extinct. If this is allowed, these countries risk losing complex ecosystem services and social, historical, and cultural relationships that have persisted 
1073 between human primates and nonhuman primates over many thousands of years (Fuentes, 2012).

1074 These countries also risk the destabilizing consequences of habitat degradation, pollution,

1075 climate change, and food insecurity for their human populations Because Brazil, Madagascar,

1076 Indonesia and the Democratic Republic of the Congo harbor 65\% of the world's primate species,

1077 these countries are of critical significance for global primate conservation. Consequently, urgent

1078 local and global action must be taken to reverse the current situation of impending primate

1079 extinctions.

1080 ACKNOWLEDGEMENTS

1081 Paul A. Garber is forever grateful to Jennifer A. Garber for inspiring him to redirect his efforts to 1082 protecting the world's threatened primate populations. Alejandro Estrada is thankful to Erika and Alex for always supporting my interests in primate reaearch and conservation. Alejandro Estrada would like to thank P. A. Garber and all our couathors for their collaboration to move this article forward.

\section{REFERENCES}

Abernethy KA, Coad L, Taylor G, Lee ME, Maisels F. 2013. Extent and ecological consequences of hunting in Central African rainforests in the twenty-first century. Philosophical Transactions of the Royal Society London. B Biological Sciences 368:DOI: 10.1098/rstb.2012.0303.

Abernethy KA, Maisels F, White LJT. 2016. Environmental Issues in Central Africa. Annual Review of Environment and Resources 41:1-33. DOI: 10.1146/annurev-environ-110615085415.

ABIEC BRAZIL. 2016. Brazilian Livestock Profile Annual Report 2016; http://www.newsprime.com.br/img/upload2/2016_FolderPerfil_EN.pdf

Abood SA, Lee JSH, Burivalova Z, Garcia-Ulloa J, Koh LP. 2015. Relative contributions of the logging, fiber, oil palm, and mining industries to forest loss in Indonesia. Conservation Letters, 8:58-67. DOI: 10.1111/conl.12103.

Adams WA, Hutton J. 2007. People, parks and poverty: Political ecology and biodiversity conservation. Conservation and Society 5:147 -183 Available at: http://www.conservationandsociety.org/text.asp?2007/5/2/147/49228

Agustin IK, Anggriawan A, Miliyanawati BK, Setiawan A. 2016, Distribution of Sumatran surili (Presbytis melalophos) in Kerinci and Jambi Province Indonesia. Project report. Primate Conservation Inc. Available at http://www.primate.org/support.htm.

Ahrends A., Hollingsworth PM, Ziegler AD, Fox JM, Chen H, Su Y, Xu J. 2015. Current trends of rubber plantation expansion may threaten biodiversity and livelihoods. Global Environmental Change 34:48-58.

Alamgir M, Campbell MJ, Sloan S, Goosem M, Clements GR, Mahmoud MI, Laurance WF. 2017. Economic, socio-political and environmental risks of road development in the tropics. Current Biology 27:R1130-R1140.

Alisjahbana AS, Busch Jonah M. 2017. Forestry, forest fires, and climate change in Indonesia. Bulletin of Indonesian Economic Studies 53:111-136 DOI:10.1080/00074918.2017.1365404

Almeida MAB, Santos E, Cardoso JC, Fonseca DF, Noll CA, Silveira VR, Maeda AY, Souza RP, Kanamura C \& Brasil RA. 2012. Yellow fever outbreak affecting Alouatta populations in Southern Brazil (Rio Grande do Sul State), 2008-2009. American Journal of Primatology 74:68-76. 
1118

1119

1120

1121

1122

1123

1124

1125

1126

1127

1128

1129

1130

1131

1132

1133

1134

1135

1136

1137

1138

1139

1140

1141

1142

1143

1144

1145

1146

1147

1148

1149

1150

1151

1152

1153

1154

1155

1156

1157

1158

1159

1160

1161

1162

1163

Alsamawi A, Murray J, Lenzen M, Moran D, Kanemoto K. 2014. The Inequality Footprints of Nations: A novel approach to quantitative accounting of income inequality. PLoS ONE 9:e110881.

Alvarez-Berríos NL, Aide TM. 2015. Global demand for gold is another threat for tropical forests. Environmental Research Letters. 10:e 014006.

Alves RRN, Souto WMS, Barboza RRD. 2010. Primates in traditional folk medicine: A world overview. Mammalian Review 40:155-180.

Amsterdam Declaration, 2015. The Amsterdam Declaration 'Towards Eliminating Deforestation from Agricultural Commodity Chains with European Countries'.

Available at https://www.euandgvc.nl/documents/publications/2015/december/7/declarations.

Ancrenaz M, Oram F, Ambu L, Lackman I, Ahmad E, Elahan H, Kler H, Abram NK, Meijaard E. 2015. Of Pongo, palms and perceptions: a multidisciplinary assessment of Bornean orang-utans Pongo pygmaeus in an oil palm context. Oryx 49:465-472.

Ancrenaz, M, Gumal M, Marshall AJ, Meijaard E, Wich SA, Husson S. 2016. Pongo pygmaeus. The IUCN Red List of Threatened Species 2016: e.T17975A17966347 Available at http://dx.doi.org/10.2305/IUCN.UK.2016-1.RLTS.T17975A17966347.en (Downloaded on 12 November 2017).

André C, Kamate C, Mbonzo P, Morel D, Hare B. 2008. The conservation value of Lola Ya Bonobo Sanctuary. In: Takeshi F, Thompson J, eds. The bonobos: Behaviour, ecology and conservation. Springer Press, 303-322.

Anonymous. 2003. Amapá biodiversity corridor. Neotropical Primates 11:191-192.

Araújo MB, Cabeza M, Thuiller W, Hannah L, Williams PH. 2004. Would climate change drive species out of reserves? An assessment of existing reserve-selection methods. Global Change Biology 10:1618-1626.

Ashraf J, Pandey R, de Jong W. 2016. Assessment of bio-physical, social and economic drivers for forest transition in Asia-Pacific region. Forest Policy and Economics DOI: 10.1016/j.forpol.2016.07.008.

Ayres JM. 1986. The conservation status of the white uakari. Primate Conservation 7:22-26.

Ayres JM, Mittermeier RA \& Constable ID. 1982. Brazilian tamarins on the way to extinction? Oryx 16:329-333.

Ayres JM, Fonseca, GAB da, Rylands AB, Queiroz HL. Pinto LP de S, Masterson D, Cavalcanti RB. 2005. Os Corredores Ecológicos das Florestas Tropicais do Brasil. Sociedade Civil Mamirauá. 256p.

Baaz ME, Olsson O. 2011. Feeding the Horse: Unofficial economic activities within the police force in the Democratic Republic of the Congo. African Security 4:223-241. DOI: 10.1080/19392206.2011.628629.

Bakwaye Flavien N, Vanhove, W., Termote C, Van Damme P. 2016. Importance of traditional protected areas for the collection of medicinal plants, Kongo-Central (DRC). African Journal of Ecology 54:479-487.

Ballou JD, Kleiman DG, Mallinson JJC, Rylands AB, Valladares-Padua CB, Leus K. 2002. History, management and conservation role of the captive lion tamarin populations. In: Kleiman DG, Rylands AB, eds. Lion Tamarins: Biology and Conservation. Smithsonian Institution Press, 95-114.

Banes GL, Galdikas BMF, Vigilant L. 2016. Reintroduction of confiscated and displaced mammals risk outbreeding and introgression in natural populations, as evidenced by orangutans of divergent subspecies. Scientific Reports 6:22026. 
1164

1165

1166

1167

1168

1169

1170

1171

1172

1173

1174

1175

1176

1177

1178

1179

1180

1181

1182

1183

1184

1185

1186

1187

1188

1189

1190

1191

1192

1193

1194

1195

1196

1197

1198

1199

1200

1201

1202

1203

1204

1205

1206

1207

1208

1209

Barrett MA, Ratsimbazafy J. 2009. Luxury bushmeat trade threatens lemur conservation. Nature 461:470-470.

Barrett MA, Brown JL, Junge RE, Yoder AD. 2013. Climate change, predictive modeling and lemur health: Assessing impacts of changing climate on health and conservation in Madagascar. Biological Conservation 157:409-422.

Baylis K, Honey-Rosés J, Börner J, Corbera E, Ezzine-de-Blas D, Ferraro PJ, Lapeyre R, Persson UM, Pfaff A, Wunder S. 2016. Mainstreaming impact evaluation in nature conservation. Conservation Letters 9:58-64.

Beck B, Walkup K, Rodrigues M, Unwin S, Travis D, Stoinski, T. 2007. Best Practice Guidelines for the Re-introduction of Great Apes. IUCN SSC Primate Specialist Group, Gland, Switzerland. 48pp. Availabl at https://portals.iucn.org/library/node/9065.

Beaudrot L, Ahumada JA, O'Brien T, Alvarez-Loayza P, Boekee K, Campos-Arceiz A, Eichberg D, Espinosa S, Fegraus E, Fletcher C, Gajapersad K, Hallam C, Hurtado J, Jansen PA, Kumar, E. Larney, M. Lima G. M., C. Mahony, E. H. Martin, A. McWilliam, B. Mugerwa, M. Ndoundou-Hockemba, A J, Razafimahaimodison C, Romero-Saltos H, Rovero F, Salvador J, Santos F, Sheil D, Spironello WR, Willig MR, Winarni NL, Zvoleff, S. J. Andelman. 2016. Standardized assessment of biodiversity trends in tropical forest protected areas: The end is not in sight. PLoS Biology 14:e1002357.

Bennett EL. 2002. Is there a link between wild meat and food security? Conservation Biology 16: $588-590$.

Bennett EL, Eves HE, Robinson JG, Wilkie DS. 2002. Why is eating bushmeat a biodiversity crisis? Conservation in Practice 3:28-29.

Bermejo M, Rodríguez-Teijeiro JD, Illera G, Barroso A, Vilà C, Walsh PD. 2006. Ebola outbreak killed 5000 gorillas. Science 314:1564.

Bernard E, Penna LAO, Araújo E. 2014. Downgrading, downsizing, degazettement, and reclassification of protected areas in Brazil. Conservation Biology 28:939-950.

Bersacola E, Svensson MS, Bearder SK, Mills M, and Nijman V. 2014. Hunted in AngolaSurveying the bushmeat trade. Swara Jan-March 2014:31-36. 10.1017/s0030605313001439

Beyene T, Ludwig F, Franssen W. 2013. The potential consequences of climate change in the hydrology regime of the Congo River Basin. In: Haensler A, Jacob D, Kabat P, Ludwig F, eds. Climate Change Scenarios for the Congo Basin. Hamburg, Germany: Climate Service Centre, Germany, 1-44.

Bicca-Marques JC, Freitas DS. 2010. The role of monkeys, mosquitoes, and humans in the occurrence of a yellow fever outbreak in a fragmented landscape in south Brazil: protecting howler monkeys is a matter of public health. Tropical Conservation Science 3:31-42.

Bicca-Marques JC, Calegaro-Marques C. 2014. Parasite sharing between humans and nonhuman primates and the hidden dangers to primate conservation. Zoologia 31:313-315.

Bicca-Marques JC, Calegaro-Marques C, Rylands AB, Strier KB, Mittermeier RA, Almeida MAB, Castro PHG, Chaves ÓM, Ferraz LP, Fortes VB, Hirano ZMB, Jerusalinsky L, Kowalewski M, Martins WP, Melo FR, Mendes SL, Neves LG, Passos FC, Port-Carvalho M, Ribeiro S, Romano APM, Ruiz-Miranda CR, Santos EO, Souza Jr JC \& Teixeira DS. 2017. Yellow fever threatens Atlantic Forest primates. Science Advances 3:e1600946/tab-e-letters.

Bowler DE, Buyung-Ali LM, Healey JR, Jones JP, Knight TM, Pullin AS. 2012. Does community forest management provide global environmental benefits and improve local welfare? Frontiers in Ecology and the Environment, 10:29-36. 
1210

1211

1212

1213

1214

1215

1216

1217

1218

1219

1220

1221

1222

1223

1224

1225

1226

1227

1228

1229

1230

1231

1232

1233

1234

1235

1236

1237

1238

1239

1240

1241

1242

1243

1244

1245

1246

1247

1248

1249

1250

1251

1252

1253

1254

1255

Brashares JS, Abrahms B, Fiorella KJ, Golden CD, Hojnowski CE, Marsh RA, McCauley DJ, Nuñez TA, Seto K, Withey L. 2014. Wildlife decline and social conflict. Policies aimed at reducing wildlife-related conflict must address the underlying causes. Science 345:376-378.

Brancalion PH, Viani RA, CalmonM, Carrascosa H, Rodrigues RR. 2013. How to organize a large-scale ecological restoration program? The framework developed by the Atlantic Forest Restoration Pact in Brazil. Journal of Sustainable Forestry, 32:728-744.

Brancalion LC, Garcia R, Loyola RD, Rodrigues RR, Pillar VD, Lewinsohn TM. 2016. A critical analysis of the Native Vegetation Protection Law of Brazil (2012): updates and ongoing initiatives. Nature Conservation 14:1-15.

Brazil, MA-IBDF, FBCN. 1979. Plano do Sistema de Unidades de Conservação do Brasil. Ministério da Agricultura (MA), Instituto Brasileiro de Desenvolvimento Florestal (IBDF), and Fundação Brasileira para a Conservação da Natureza (FBCN), Brasília, Brazil.

Brazil, MMA. 2002. Biodiversidade Brasileira: Avaliação e Identificação de Áreas e Ações Prioritárias para Conservação, Utilização Sustentável e Repartição de Benefícios da Biodiversidade Brasileira. Secretaria de Biodiversidade e Florestas (SBF), Ministério do Meio Ambiente (MMA), Brasília, Brazil.

Brasil, 2014. Ministério do Meio Ambiente. Portaria $n^{\circ}$ 444, 17 de dezembro de 2014. 2014. Lista Nacional Oficial de Espécies da Fauna Ameaçada de Extinção. Diário Oficial da República Federativa do Brasil. Brasília, DF, 17 de dez. de 2014. Seção I, p.121-126.

Britt A, Welch C, Katz A. 2004. Can small, isolated primate populations be effectively reinforced through the release of individuals from a captive population? Biological Conservation 115:319-327.

Brodie JF, Helmy OE, Brockelman WY, Maron JL. 2009. Bushmeat poaching reduces the seed dispersal and population growth rate of a mammal-dispersed tree. Ecological Applications 19:854-863.

Brown JL., Yoder AD. 2015. Shifting ranges and conservation challenges for lemurs in the face of climate change. Ecology and Evolution, 5:1131-1142. DOI:10.1002/ece3.1418.

Bublitz DC, Wright PC, Rasambainarivo FT, Arrigo-Nelson SJ, Bodager JR, Gillespie TR. 2015. Pathogenic enterobacteria in lemurs associated with anthropogenic disturbance. American Journal of Primatology 77:330-337.

Bugher JC. 1951. The mammalian host in yellow fever. In: Yellow fever. In: Strode GK, ed. McGraw Hill, 299-384.

Burivalova Z, Hua F, Pin Koh L, Garcia G, Putz F. 2017. A critical comparison of conventional, certified, and community management of tropical forests for timber in terms of environmental, economic, and social variables. Conservation Letter 10:4-14.

Burgess MG, Christopher C, Fredston-Hermann A, Pinsky ML, Gaines SD, Tilman D, Polasky S. 2017. Range contraction enables harvesting to extinction Proceedings of the National Academic of Sciences 114:3945-3950 DOI: 10.1073/pnas.1607551114.

Busch J, Engelmann J. 2018. Cost-effectiveness of reducing emissions from tropical deforestation, 2016-2050. Environmental Research Letters. 13: DOI: 10.1088/17489326/aa907c

Butchart SHM, Clarkem, Smith RJ, Sykes RE, Scharlemann JPW, Harfoot M, Buchanan GM, Angulo A, Balmford A, Bertzky B, Brooks TM, Carpenter KE, Comeros-Raynal MT, Cornell J, Ficetola GF, Fishpool LDC, Fuller RA, Geldmann J, Harwell H, HiltonTaylor C, Hoffmann M, Joolia A, Joppa L, Kingston N, May I, Milam A, Polidoro B, 
1256

1257

1258

1259

1260

1261

1262

1263

1264

1265

1266

1267

1268

1269

1270

1271

1272

1273

1274

1275

1276

1277

1278

1279

1280

1281

1282

1283

1284

1285

1286

1287

1288

1289

1290

1291

1292

1293

1294

1295

1296

1297

1298

1299

1300

1301

\section{Ralph G, Richman N, Ondinini C, Segan DB, Skolnik B, Spalding MD, Stuart SN,} Symes A, Taylor J, Visconti P, Watson JEM, Wood L, Burgess ND. 2015. Shortfalls and solutions for meeting national and global conservation area targets. Conservation Letters DOI: $10.1111 /$ conl.12158

Butler RA, Laurance WF. 2008. New strategies for conserving tropical forests. Trends in Ecology and Evolution 974:1-4.

Butt N, Beyer HL, Bennett JR, Biggs D, Maggini R, Mills M, Renwick AR, Seabrooke LM, Possingham HP. 2013. Biodiversity risks from fossil fuel extraction. Science 342:425-426.

Campbell-Smith GA, Hubert VP, Simanjorang, Williams L, Linkie NM. 2010. Local attitudes and perceptions toward crop-raiding by orangutans (Pongo abelii) and other nonhuman primates in northern Sumatra, Indonesia. American Journal of Primatology 71:111.

Canale GR, Peres CA, Guidorizzi CE, Gatto CAF, Kierulff MCM. 2012. Pervasive defaunation of forest remnants in a tropical biodiversity hotspot. PLOS ONE 7: DOI: 10.1371/journal.pone.0041671.

Car D, Queirogas VL \& Pedersoli MA. 2015, Translocation and radio-telemetry monitoring of pygmy marmoset, Cebuella pygmaea (Spix, 1823), in the Brazilian Amazon. Brazilian Journal of Biology 75:91-97.

Carlson KM, Heilmayr R, Gibbs HK, Noojipady P, Morton DC, Walker NF, Paoli GP, Kremen C. 2018. Effect of oil palm sustainability certification on deforestation and fire in Indonesia. Proceedings of the National Academy of Sciences 115:121-126.

Carrasco L, Larrosa C, Milner-Gulland E, Edwards D. 2014. A double-edged sword for tropical forests. Science 346: DOI: 10.1126/science.1256685 PMID: 25278600.

Carvalho RS, Silva DA, Loiola, S, Pereira DG, Carvalho EF, Bergallo HG. 2013. Molecular identification of a Buffy-tufted-ear marmoset (Callithrix aurita) incorporated in a group of invasive marmosets in the Serra dos Orgãos National Park, Rio de Janeiro- Brazil. Forensic Science International: Genetics Supplement Series 4:230-231.

Caughlin TT, Ferguson JM, Lichstein JW, Zuidema PA, Bunyavejchewin S, Levey DJ. 2015. Loss of animal seed dispersal increases extinction risk in a tropical tree species due to pervasive negative density dependence across life stages. Proceedings of the Royal Society $B$ 28:20142095.

CBD. 2011. Strategic Plan for Biodiversity 2011-2020: Aichi Targets. CBD-UNEP.

CBFP. 2006. Congo Basin Forest Partnership-The forests of the Congo Basin: State of the Forest 2006. Kinshasa, DRC: CBFP.

Ceballos G, Ehrlich PR. 2002 Mammal population losses and the extinction crisis. Science 296:904-907. DOI: 10.1126/science.1069349.

Chandra P. 2017. Conservation of nature and natural resources through spirituality. Applied Ecology and Environmental Sciences 5:24-34 DOI: 10.12691/aees-5-2-1.

Challender DWS, MacMillan DC. 2014. Poaching is more than an enforcement problem. Conservation Letters 7: 484-494.

Chapman CA, Gillespie TR \& Goldberg TL. 2005. Primates and the ecology of their infectious diseases: how will anthropogenic change affect host-parasite interactions? Evolutionary Anthropology 14:134-144.

Chapman CA, Bonnell TR, Gogarten JF, Lambert JE, Omeja PA, Twinomugisha D, Wasserman MD, Rothman JM. 2013. Are primates ecosystem engineers? International Journal of Primatology. 34:1-14. 
1302

1303

1304

1305

1306

1307

1308

1309

1310

1311

1312

1313

1314

1315

1316

1317

1318

1319

1320

1321

1322

1323

1324

1325

1326

1327

1328

1329

1330

1331

1332

1333

1334

1335

1336

1337

1338

1339

1340

1341

1342

1343

1344

1345

1346

1347

CIA. 2017. The world Factbook. Available at https://www.cia.gov/library/publications/resources/the-world-factbook/

Clayton S, Myers G. 2009. Conservation Psychology: Understanding and Promoting Human Care for Nature. Wiley-Blackwell, Chichester.

Coimbra-Filho AF. 2004. Os primórdios da primatologia no Brasil. In: Mendes SL, Chiarello AG, eds. A Primatologia no Brasil - volume 8. Sociedade Brasileira de Primatologia. Vitória, Brasil. 11-35.

Coimbra-Filho AF, Mittermeier RA. 1976. Hybridization in the genus Leontopithecus, Leontopithecus r. rosalia (Linneus, 1766) x L. r. chrysomaleas (Kuhl, 1830) (Callitrichidae, Primates). Revista Brasileira de Biologia 36:129-137.

Consoli RAGB, Oliveira RL. 1994. Principais mosquitos de importância sanitária no Brasil. Fiocruz, Rio de Janeiro. 228 p. ISBN 85-85676-03-5.

Courchamp F, Angulo E, Rivalan P, Hall RJ, Signoret L, Bull L, and Meinard Y. 2006. Rarity Value and species extinction: The Anthropogenic Allee Effect. PloS Biology 4:e415. DOI: 10.1371/journal.pbio.0040415.

CPI. 2016. Corruption Perception Index. Transparency International. Available at https://www.transparency.org/news/feature/corruption_perceptions_index_2016 (consulted 20-october-2017).

Crist E, Mora C, Engelman R. 2017. The interaction of human population, food production, and biodiversity protection. Science 356:260-264.

Da Silva FA, Canale GR, Kierulff MCM, Duarte GT, Paglia AP Bernardo CS. 2016. Hunting, pet trade, and forest size effects on population viability of a critically endangered Neotropical primate, Sapajus xanthosternos (Wied-Neuwied, 1826). American Journal of Primatology 78:950-960.

Dalerum, F. 2014, Identifying the role of conservation biology for solving the environmental crisis. Ambio 43: 839-846.

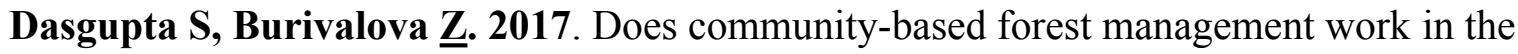
tropics? Mongabay Series: Conservation Effectiveness Available at https://news.mongabay.com/2017/09/does-forest-certification-really-work/

Daszak P, Cunningham AA, Hyatt AD. 2000. Emerging infectious disease of wildlife: threats to biodiversity and human health. Science 287:443-449.

Davenport T, Fakih S, Kimiti S, Kleine L, Foley L, De Luca D. 2017. Zanzibar's endemic red colobus Piliocolobus kirkii: First systematic and total assessment of population, demography and distribution. Oryx, 1-9. DOI: 10.1017/S003060531700148X.

Day SR, Ramarokoto REAF, Sitzmann BD, Randriamboahanginjatovo R, Ramanankirija H, Rence V, Randrianindrina A, Ravololonarivo G, Louis Jr EE. 2009. Re-introduction of diademed sifaka (Propithecus diadema) and black and white ruffed lemurs (Varecia variegata editorum) at Analamazaotra Special Reserve, eastern Madagascar. Lemur News 14:32-37.

Debroux L, Hart T, Kaimowitz D, Karsenty A, Topa G, eds. 2007. Forests in Post-Conflict Democratic Republic of Congo: Analysis of a Priority Agenda. A joint report by teams of the World Bank, Center for International Forestry Research (CIFOR), Centre International de Recherche Agronomique pour le Développement (CIRAD), African Wildlife Foundation, Conseil National des ONG de Développement du Congo, Conservation International, Groupe de Travail Forêts, Ligue Nationale des Pygmées du Congo, Netherlands Development Organisation, Réseau des Partenaires pour l'Environnement au Congo, 
Wildlife Conservation Society, Woods Hole Research Center, World Agroforestry Centre and World Wide Fund for Nature. CIFOR, World Bank and CIRAD, Washington, DC. Available at https://www.cifor.org/publications/pdf_files/Books/BCIFOR0701.pdf

Detogne N, Ferreguetti AC, Mello JHF, Santana MC, Dias AC, Mota NCJ, Gonçalves AEC, Souza CPS, Bergallo HG. 2017. Spatial distribution of buffy-tufted-ear (Callithrix aurita) and invasive marmosets (Callithrix spp.) in a tropical rainforest reserve in southeastern Brazil. American Journal of Primatololy. Available at https://doi.org/10.1002/ajp.22718.

Dixon J, Gulliver A, Gibbon D. 2001. Farming Systems and Poverty: improving farmers' livelihoods in a changing world. FAO and World Bank, Rome and Washington D.C. Avilable at www.fao.org/3/a-ac349e.pdf

Do Nascimento RA, Schiavetti A, Montaño RAM. 2013. An assessment of illegal capuchin monkey trade in Bahia State, Brazil. Neotropical Biology and Conservation 8:79-87.

Dobrovolski R, Loyola RD, Guilhaumon F, Gouveia SF, Diniz-Filho JAF. 2013. Global agricultural expansion and carnivore conservation biogeography. Biological Conservation 165:162-170.

Dobrovolski R, Rattis L. 2014. Brazil should help developing nations to foster agriculture and environmental protection. Frontiers in Ecology and the Environment, 12:376-376.

Dobrovolski R, Loyola R, Da Fonseca GAB, Diniz-Filho JAF, Araújo MB. 2014. Globalizing conservation efforts to save species and enhance food production. Bioscience 64:539-545.

Dolins F. L., A. Jolly, H. Rasamimanana, J. Ratsimbazafy, A. T. Feistner, F. Ravoavy. 2010. Conservation education in Madagascar: Three case studies in the biologically diverse island-continent. American Journal Primatology 72:391-406.

Donati G, Ramanamanjato J-B, Ravoahangy AM, Vincelette M. 2007. Translocation as a conservation measure for an endangered species in the littoral forest of southeastern Madagascar: the case of Eulemur collaris. In: Ganzhorn JU, Goodman SM, Vincelette M, eds. Biodiversity, Ecology and Conservation of littoral Forest Ecosystems in southeastern Madagascar, Tolagnaro (Fort Dauphin). Smithsonian Press, 237-245.

Dosen J, Raboy BE, Fortib MJ. 2017. Restoration strategies to improve connectivity for golden-headed lion tamarins (Leontopithecus chrysomelas) in the Bahian Atlantic Forest, Brazil. International Journal of Primatology 38:962-983 DOI: 10.1007/s10764-017-9991-8.

Douglas LR, Alie K. 2014. High-value natural resources: linking wildlife conservation to international conflict, insecurity, and development concerns. Biological Conservation 171:270-277.

Dupain J, Nackoney J, Vargas JM, Johnson PJ, Farfán MA, Bofaso M, Fa JE. 2012. Bushmeat characteristics vary with catchment conditions in a Congo market. Biological Conservation, 146:32-40.

Edwards DP, Sloan S, Weng L, Dirks P, Sayer J, Laurance WF. 2014. Mining and the African Environment. Conservation Letters 7:302-311. DOI: 10.1111/conl.12076.

Effiom EO, Nuñez-Iturri G, Smith HG, Ottosson U, Olsson O. 2013. Bushmeat hunting changes regeneration of African rainforests. Proceedings of the Royal Society B: Biological Sciences, 280:DOI:10.1098/rspb.2013.0246.

EP. 2017. European Parliament (EP), 2017. Resolution on Palm Oil and Deforestation of Rainforests. (2016/2222(INI)). Available at http:/www.europarl.europa.eu/sides/getDoc.do?pubRef=-// EP//NONSGML+TA+P8-TA2017-0098+0+DOC+PDF+V0//EN. 
1394

1395

1396

1397

1398

1399

1400

1401

1402

1403

1404

1405

1406

1407

1408

1409

1410

1411

1412

1413

1414

1415

1416

1417

1418

1419

1420

1421

1422

1423

1424

1425

1426

1427

1428

1429

1430

1431

1432

1433

1434

1435

1436

1437

1438

Ernst C, Mayaux P, Verhegghen A, Bodart C, Christophe M, Defourny P. 2013. National forest cover change in Congo Basin: deforestation, reforestation, degradation and regeneration for the years 1990, 2000 and 2005. Global Change Biology 19:1173-1187. DOI: $10.1111 / \mathrm{gcb} .12092$.

Escarlate-Tavares F, Valença-Montenegro MM, Jerusalinsky L. (orgs.). 2016. Plano de Ação Nacional para a Conservação dos Mamíferos da Mata Atlântica Central. ICMBio. Brasília, Brazil.

Estrada A, Garber PA, Rylands AB, Roos C, Fernandez-Duque E, Di Fiore A, Nekaris KAI, Nijman V, Heymann EW, Lambert JE, Rovero F, Barelli C, Setchell JM, Gillespie TR, Mittermeier RA, Arregoitia LV, Guinea M, Gouveia S, Dobrovolski R, Shanee S, Shanee N, Boyle SA, Fuentes A, MacKinnon KC, Amato KR, Meyer ALS, Wich S, Sussman RW, Pan R, Kone I, Li B. 2017. Impending extinction crisis of the world's primates: Why primates matter. Science Advances 3:e1600946.

Estrada A, Raboy BE, Oliveira LC. 2012. Agroecosystems and primate conservation in the tropics: A review. American Journal of Primatology 74:696-711.

Estrada, A. 2013. Socioeconomic contexts of primate conservation: population, poverty, global economic demands and sustainable land use. American Journal of Primatology 75:30-45.

EU. 2010. Regulation (EU) No 995/2010 of the European Parliament and of the Council of 20 October 2010 Laying down the Obligations of Operators Who Place Timber and Timber Products on the Market Text with EEA Relevance. Available at http://eurlex.europa.eu/legal-content/EN/TXT/?uri=CELEX:32010R0995.

Fa JE, Olivero J, Farfán MÁ, Márquez AL, Vargas JM, Real R, Nasi R. 2014. Integrating Sustainable Hunting in Biodiversity Protection in Central Africa: Hot Spots, Weak Spots, and Strong Spots. PLOS ONE 9: e112367.

FAO, IFAD and WFP. 2015. The State of Food Insecurity in the World 2015. Meeting the 2015 international hunger targets: taking stock of uneven progress. Rome, FAO.Available at http://www.fao.org/3/a-i4646e.pdf.

Federman S, Dornburg A, Daly DC, Downie A, Perry GH, Yoder AD, Sargis EJ, Richard A, Donoghue MJ, Baden AL. 2016. Implications of lemuriform extinctions for the Malagasy flora. Proceedings of the National Academy of Sciences 113:504-5046.

Ferreira FS, Fernandes-Ferreira H, Neto NAL, Brito SV, Alves RRN. 2013. The trade of medicinal animals in Brazil: current status and perspectives. Biodiversity and Conservation 22:839-870.

Ferreira LV, Lemos de Sá R, Buschbacher, Batmanian G, Cardoso da Silva JM, Arruda MB, Moretti E, S.N. de Sá LF, Falcomer J, Bampi MJ. 2001. Identificação de áreas prioritárias para a conservação da biodiversidade por meio da representatividade das unidades de conservação e tipos de vegeteção nas ecorregiões da Amazônia brasileira. Pages 268-286 in A. Veríssimo, A. Moreira, D. Sawyer, I. dos Santos, L. P. Pinto and J. P. R Capobianco, editors. Biodiversidade na Amazonia Brasileira, Editora Estação Liberdade, Instituto Socioambiental, São Paulo, Brasil.

Fialho MS, Ludwig G, Valença-Montenegro MM. 2016. Legal international trade in live Neotropical Primates originating from South America. Primate Conservation 30:1-6.

Fialho MS, Printes RC, Almeida MAB, Laroque PO, Santos E, Jerusalinsky L. 2012. Avaliação do impacto da epizootia de Febre Amarela sobre as populações de primatas não humanos nas unidades de conservação do Rio Grande do Sul, Brasil. Biotemas 25:217-225. 
1439

1440

1441

1442

1443

1444

1445

1446

1447

1448

1449

1450

1451

1452

1453

1454

1455

1456

1457

1458

1459

1460

1461

1462

1463

1464

1465

1466

1467

1468

1469

1470

1471

1472

1473

1474

1475

1476

1477

1478

1479

1480

1481

1482

1483

1484

1485

Finer M, Babbitt B, Novoa S, Ferrarese F, Pappalardo SE, De Marchi M, Saucedo M, Kumar A. 2015. Future of oil and gas development in the western Amazon. Environmental Research Letters 10: e024003.

Fobissie K. 2015. Landscape approaches in the Congo Basin: linking the Democratic Republic of Congo's Emission Reduction Program (ERP) and the Central Africa Regional Program for the Environment (CARPE). In: Minang PA, van Noordwijk, M, Freeman OE, Mbow C, de Leeuw J, Catacutan D. eds. Climate-Smart Landscapes: Multifunctionality in Practice. Nairobi, Kenya: World Agroforestry Centre (ICRAF), 361-371. Available at www.asb.cgiar.org/climate-smart-landscapes/chapters/chapter25.pdf

Freudenberger K. 2010. Paradise lost? Lessons from 25 years of USAID environment programs in Madagascar. International Resources Group. Washington, D.C. 1-106. Avilable at https://www.usaid.gov/sites/default/files/.../paradise_lost_25years_env_programs.pdf

Freitas DS, Bicca-Marques JC. 2011. Evaluating the impact of an outbreak of yellow fever on the black-and-gold howler monkey in southern Brazil. Oryx 45:16-17.

Fuentes, A. 1998. Current status and future viability for the Mentawai primates. Primate Conservation 17: 111-116.

Fuentes A. 2002. Monkeys, Humans, and Politics in the Mentawai islands: No Simple Solutions in a Complex World In: Fuentes A, Wolfe LD, eds. Primates Face to Face: The Conservation Implications of Human and Nonhuman Primate Interconnections. Cambridge University Press, 187-207.

Fuentes A. 2012. Ethnoprimatology and the anthropology of the human-primate interface. Annual Review of Anthropology. 41:101-117.

Gamba M, Randrianarison RM, Tort V, Bounous G, Zaborra CA, Ratsimbazafy J, Giacoma C. 2013. Maromizaha: Conservation and Community Involvement. In: Schwitzer C, Mittermeier RA, Davies N, Johnson S, Ratsimbazafy J, Razafindramanana J, Louis Jr. EE, Rajaobelina S, eds. Lemurs of Madagascar: A Strategy for Their Conservation 20132016. Bristol, UK: IUCN SSC Primate Specialist Group, Bristol Conservation and Science Foundation, and Conservation International, 155-156.

Ganzhorn JU. 1987. A possible role of plantations for primate conservation in Madagascar. American Journal of Primatology 12:205-215.

Ganzhorn, JU, Abraham JP. 1991. A possible role of plantations for lemur conservation in Madagascar: food for folivorous species. Folia Primatologica 56:171-176.

Garcia LC, Ribeiro DB, Oliveira-Roque F, Ochoa-Quintero, JM, Laurance WF. 2017. Brazil's worst mining disaster: Corporations must be compelled to pay the actual environmental costs. Ecological Applications 27: 5-9.

García-Ulloa J, Koh LP. 2016. Payment for ecosystem services the role of REDD+ in primate conservation. In: Wich SA, Marshal AJ, eds. An Introduction to Primate Conservation. Oxford University Press, 257-268.

Gardner CJ, Davies ZG. 2014. Rural bushmeat consumption within multiple-use protected areas: qualitative evidence from southwest Madagascar. Human Ecology 42:21-34.

Gaveau DL, Epting AJ, Lyne O, Linkie M, Kumara I, Kanninen M, Leader-Williams N. 2009. Evaluating whether protected areas reduce tropical deforestation in Sumatra. Journal of Biogeography DOI: 10.1111/j.1365-2699.2009.02147.x.

Gaveau D, Wich SA, Marshall AJ. 2016. Are protected areas conserving primate habitat in Indonesia? In: Wich SA, Marshal AJ, eds. An Introduction to Primate Conservation. Oxford University Press. DOI: 10.1093/acprof:oso/9780198703389.003.0012.

Gavin L. 2017. Rebellion and conflict minerals in North Kivu. Conflict Trends 1:13-19. 
1486

1487

1488

1489

1490

1491

1492

1493

1494

1495

1496

1497

1498

1499

1500

1501

1502

1503

1504

1505

1506

1507

1508

1509

1510

1511

1512

1513

1514

1515

1516

1517

1518

1519

1520

1521

1522

1523

1524

1525

1526

1527

1528

1529

1530

1531

Gilardi K, Gillespie T, Leendertz F, Macfie E, Travis D, Whittier C, Williamson E. 2015. Best Practice Guidelines for Health Monitoring and Disease Control in Great Ape Populations (IUCN/SSC Primate Specialist Group). Available at www.primate-sg.org/ best_practice_disease.

Global Invasive Species Database. 2018. Species profile: Macaca fascicularis. Available at http://www.iucngisd.org/gisd/speciesname/Macaca\%20fascicularis on 03-02-2018.

Gogarten JF, Calvignac-Spencer S, Leendertz FH. 2017. Ebola virus disease. In: Fuentes A, ed. The International Encyclopedia of Primatology. John Wiley and Sons. DOI: 10.1002/9781119179313.wbprim0390.

Golden CD. 2009. Bushmeat hunting and use in the Makira Forest, north-eastern Madagascar: a conservation and livelihoods issue. Oryx 43:386-392.

Golden CD, Gupta AC, Vaitla B, and Myers SS. 2016. Ecosystem services and food security: assessing inequality at community, household and individual scales. Environmental Conservation 43:381-388. 10.1017/s0376892916000163

Goldsmith P, Cohn A. 2017. Commercial agriculture in tropical environments. Tropical Conservation Science 10:doi.org/10.1177/1940082917727994.

Gore ML, Ratsimbazafy J, Lute ML. 2013. Rethinking corruption in conservation crime: Insights from Madagascar. Conservation Letters 6:430-438.

Gouel C, Houssein G. 2017. Nutrition Transition and the Structure of Global Food Demand (April 7, 2017). IFPRI Discussion Paper 1631. Available at https://ssrn.com/abstract=2950524.

Gould L, Sauther ML. 2016. Going, Going, Gone... Is the iconic ring-tailed lemur (Lemur catta) headed for imminent extirpation? Primate Conservation 30:89-101.

Gouveia SF, Souza-Alves JP, Rattis L, Dobrovolski R, Jerusalinsky L, Beltrão-Mendes R, Ferrari SF. 2016. Climate and land use changes will degrade the configuration of the landscape for titi monkeys in eastern Brazil. Global Change Biology 22:2003-2012.

Gouveia SF, Souza-Alves JP, de Souza BB, Beltrão-Mendes R, Jerusalinsky L, Ferrari SF. 2017. Functional planning units for the management of an endangered Brazilian titi monkey. American Journal of Primatology 79:1-8.

Graham TL, Matthews HD, Turner SE. 2016. A global-scale evaluation of primate exposure and vulnerability to climate change. International Journal of Primatology 37:158-174.

GWF, 2018. Global Forest Watch. Available at http://www.globalforestwatch.org/country/COD. Hansen MC, Potapov PV, Moore R, Hancher M, Turubanova SA, Tyukavina A, Thau D, Stehman SV, Goetz SJ, Loveland TR, Kommareddy A, Egorov A, Chini L, Justice CO, Townshend JRG. 2013. High-resolution global maps of 21st-century forest cover change. Science 342:850-853.

Hanski I, Zurita GA, Bellocq MI Rybicki, J. 2013. Species-fragmented area relationship. Proceedings of the National Academy of Sciences. DOI: 10.1073/pnas.1311491110.

Hanspach J, Abson DJ, Collier NF, Dorresteijn I, Schultner J, Fischer J. 2017. From tradeoffs to synergies in food security and biodiversity conservation. Frontiers in Ecology and the Environment 15:489-494.

Harich FK, Treydte AC. 2016. Mammalian wildlife diversity in rubber and oil palm plantations CAB Reviews 2016 0, No. 020 Available at http://www.cabi.org/cabreviews.

Henders S, Persson UM, Kastner T. 2015. Trading forests: land-use change and carbon emissions embodied in production and exports of forest-risk commodities. Environmental Research Letters 10:125012. 
1532

1533

1534

1535

1536

1537

1538

1539

1540

1541

1542

1543

1544

1545

1546

1547

1548

1549

1550

1551

1552

1553

1554

1555

1556

1557

1558

1559

1560

1561

1562

1563

1564

1565

1566

1567

1568

1569

1570

1571

1572

1573

1574

1575

1576

1577

Henders S, Ostwald M, Verendel V, Ibisch P. 2018. Do national strategies under the UN biodiversity and climate conventions address agricultural commodity consumption as deforestation driver? Land Use Policy 70:580-590.

Hending D, Andrianiaina A, Rakotomalala Z, Cotton S. 2017. Range extension and behavioural observations of the recently described Sheth's dwarf lemur (Cheirogaleus shethi). Folia Primatolica 88:401-408

Hickey JR, Nackoney J, Nibbelink NP, Blake S, Bonyenge A, Coxe S, Dupain J, Emetshu M, Furuichi T, Grossmann F, Guislain P, Hart J, Hashimoto C, Ikembelo B, Ilambu O, Inogwabini B-I, Liengola I, Lokasola AL, Lushimba A, Maisels F, Masselink J, Mbenzo V, Mulavwa NM, Naky P, Ndunda NM, Nkumu P, Omasombo V, Reinartz GE, Rose R, Sakamaki T, Strindberg S, Takemoto H, Vosper A, Kühl HS. 2013. Human proximity and habitat fragmentation are key drivers of the rangewide bonobo distribution. Biodiversity and Conservation 22:3085-3104.

Hicks TC, Darby L, Hart J, Swinkels J, January N, Menken S. 2010. Trade in orphans and bushmeat threatens one of the Democratic Republic of the Congo's most important populations of eastern chimpanzees (Pan troglodytes schweinfurthii). African Primates 7:118.

Hilário RR, Jerusalinsky L, Santos S, Beltrão-Mendes R, Ferrari SF. 2017. A primate at risk in Northeast Brazil: local extinctions of Coimbra Filho's titi (Callicebus coimbrai). Primates 58:343-352.

Hill R, Miller C, Newell B, Dunlop M, Gordon IJ. 2015. Why biodiversity declines as protected areas increase: The effect of the power of governance regimes on sustainable landscapes. Sustainability Science 10:357-369.

Hilser H, Sampson H, Melfi V, Tasirin JS. 2013. Sulawesi crested black macaque Macaca nigra Species Action Plan: Draft 1. Selamatkan Yaki-Pacific Institute, Manado, Indonesia. Available at www.psgb.org/pdfs/Regine_Gross_final_report_small.pdf.

Hockings KJ, McLennan, MR, Carvalho S, Ancrenaz M, Bobe R, Byrne RW, Dunbar RIM, Matsuzawa T, McGrew WC, Williamson EA, Wilson ML, Wood B, Wrangham RW, Hill CM. 2015. Apes in the Anthropocene: flexibility and survival. Trends in Ecology \& Evolution 30:215-222.

Hoffmann C, Zimmermman F, Biek R, Kuehl H, Nowak K, Mundry R, Agbor A, Angedakin S, Arandjelovic M, Blankenburg A, Brazolla G, Corogenes K, CouacyHymann E, Deschner T, Dieguez P, Dierks K, Düx A, Dupke S, Eshuis H, Formenty P, Yuh YG, Goedmakers A, Gogarten JF, Granjon A-C, McGraw S, Grunow R, Hart J, Jones S, Junker J, Kiang J, Langergraber K, Lapuente J, Lee K, Leendertz SA, Léguillon F, Leinert V, Löhrich T, Marrocoli S, Mätz-Rensing K, Meier A, Merkel K, Metzger S, Murai M, Niedorf S, De Nys H, Sachse A, van Schijndel J, Thiesen U, Ton E, Wu D, Wieler LH, Boesch C, Klee SR, Wittig RM, Calvignac-Spencer S, Leendertz FH. 2017. Persistent anthrax as a major driver of wildlife mortality in a tropical rainforest. Nature 548:82-86.

Holden MH, McDonald-Madden E. 2017. High prices for rare species can drive large populations extinct: the Anthropogenic Allee Effect revisited. Journal of Theoretical Biology 429:170-180.

Holst B, Medici E, Marinho-Filho O, Kleiman D, Leus K, Pissinatti A, Vivekananda G, Ballou J, Traylor-Holzer K, Raboy B, Passos FC, Vleeschouwer K, ValençaMontenegro MM. 2006. Lion tamarin population and habitat viability assessment workshop 
2005: final report. IUCN/SSC Conservation Breeding Specialist Group. Apple Valley, USA. 208. Available at www.icmbio.gov.br/...de...PAN_Mamíferos_da_Mata_Atlântica_Central_RED1_Parte2

Hylander K, Ehrlén J. 2013 The mechanisms causing extinction debts. Trends in Ecology and Evolution 28:341-346.

IEP. 2017. Global Peace Index 2017. Institute for Economics and Peace. Available at http://economicsandpeace.org/.

INEA. 2015. Centro de Primatologia do Rio de Janeiro. Instituto Estadual do Ambiente. Rio de Janeiro, Brasil. 292.

ITTO, 2009. DRC cancels nearly 60\% of timber contracts, In Tropical Timber Market Report: ITTO Market Information Service. p. 2. International Tropical Timber Organization (ITTO), Yokohama, Japan. Available at http://www.itto.int/

IUCN, ICCN. 2012. Bonobo (Pan paniscus): Conservation Strategy 2012-2022. Gland, Switzerland: IUCN/SSC Primate Specialist Group \& Institut Congolais pour la Conservation de la Nature. 65 pp. Available at https://portals.iucn.org/library/node/10308.

IUCN/SSC, 2013. Guidelines for Reintroductions and Other Conservation Translocations. The Reintroduction and Invasive Species Specialist Groups' Task Force on Moving Plants and Animals for Conservation Purposes Version 1.0. IUCN Species Survival Commission, Gland, Switzerland. Available at https://portals.iucn.org/library/efiles/documents/2013-009.pdf IUCN. 2017. International Union for Conservation of Nature, IUCN Red List of Threatened Species. Version 2017-3-4; www.iucnredlist.org.

Jenkins RKB, Keane A, Rakotoarivelo AR, Rakotomboavonjy V, Randrianandrianina FH, Razafimanahaka HJ, Ralaiarimalala SR, Jones JPG. 2011. Analysis of patterns of bushmeat consumption reveals extensive exploitation of protected species in Eastern Madagascar. PLOS ONE 6: e27570.

Jerusalinsky L, Talebi M, Melo FR (orgs.). 2011. Plano de Ação Nacional para a Conservação dos Muriquis - Brachyteles arachnoides e Brachyteles hypoxanthus. ICMBio. Brasília, Brasil. 141.

Jerusalinsky L. 2016. Emerging challenges for Brazilian primate conservation: perspectives from the strategic planning. Scientific Program of the XXVI Congress of the International Primatological Society. Abstract \#6515

Jones-Engel L, Engel GA, Schillaci MA, Rompis A, Putra A, Suaryana KG, Fuentes A, Beer B, Hicks S, White R, Wilson B. 2005. Primate-to-human retroviral transmission in Asia. Emerging Infectious Diseases 11:1028-1035.

Joppa LN, Pfaff A. 2009. High and far: biases in the location of protected areas. PLOS ONE 4: $1-6$.

Junge RE. 2006. Overview on the Health and Disease Ecology of Wild Lemurs: Conservation Implications. In: Gould L, Sauther ML, eds. Lemurs. Developments in Primatology: Progress and Prospect. Springer, 423-440.

Kalamandeen M, Gloor E., Mitchard E, Quincey D, Ziv G, Spracklen D, Spracklen B, Adami M, Aragão, LEOC, Galbraith D. 2018. Pervasive rise of small-scale deforestation in Amazonia. Scientific Reports 8:DOI:10.1038/s41598-018-19358-2.

Kalpers J, Williamson EA, Robbins MM, MeNeilage A, Nzamurambaho A, Lola N, Mugiri G. 2003. Gorillas in the crossfire: Assessment of population dynamics of the Virunga mountain gorillas over the past three decades. Oryx 37:326-337. 
1623

1624

1625

1626

1627

1628

1629

1630

1631

1632

1633

1634

1635

1636

1637

1638

1639

1640

1641

1642

1643

1644

1645

1646

1647

1648

1649

1650

1651

1652

1653

1654

1655

1656

1657

1658

1659

1660

1661

1662

1663

1664

1665

1666

1667

1668

Karstensen J, Peters G P, Andrew RM. 2013. Attribution of CO emissions from Brazilian deforestation to consumers between 1990 and 2010. Environmental Research Letters 8: 024005

Kastner T, Ibarrola Rivas MJ, Koch W, Nonhebel S. 2012. Global changes in diets and the consequences for land requirements for food. Proceedings of the National Academy of Sciences 109:6868-6872.

Kauano ÉE, Silva J.M.C, Michalski F. 2017. Illegal use of natural resources in federal protected areas of the Brazilian Amazon. PeerJ 5: DOI: 10.7717/peerj.3902

Keating BA, Carberry PS, Bindraban PS, Asseng S, Meinke H, Dixon J. 2010. Eco-efficient agriculture: concepts, challenges and opportunities. Crop Science 50:109-119.

Kierulff MCM, Santos GR, Canale GR, Carvalho C, Cassano C, Gouveia P, Gatto C. 2005. Plano de Manejo para a conservação do macaco-prego-do-peito-amarelo Cebus xanthosternos. Unpublished report. Instituto de Estudos Socioambientais do Sul da Bahia. Ilhéus, Brasil. 45.

Kierulff MCM. 2010. Invasive introduced golden-headed lion tamarins - a new threat to golden lion tamarins. Tamarin Tales 10:5-7.

Kierulff MCM, Ruiz-Miranda CR, de Oliveira PP, Beck BB, Martins A, Dietz JM, Rambaldi DM, Baker AJ. 2012., The Golden lion tamarin Leontopithecus rosalia: a conservation success story. International Zoo Yearbook 46:36-45.

Kitzes J, Shirley R. 2016, Estimating biodiversity impacts without field surveys: A case study in northern Borneo. Ambio 45:110-119.

KSBK. 2002. Dibalik perdagangan dagin primata di Lampung Sumatera. KSBK, Malang. Available at http://www.profauna.net/id/tentang-profauna/apa-ituprofauna\#.WmwhH6iWbIU.

Lanjouw A. 2014. Extractive Industries and Ape Conservation. In: Rainer H, White A, Lanjouw A, eds. State of the Apes. Arcus/Cambridge University Press, 127-161.

Larrosa C, Carrasco LR, Milner-Gulland E. 2016. Unintended feedbacks: challenges and opportunities for improving conservation effectiveness. Conservation Letters 9:316-326.

Latrubesse EM, Arima EY, Dunne T, Park E, Baker VR, d'Horta FM, Wight C, Wittmann F, Zuanon J, Baker PA, Ribas CC, Norgaard RB, Filizola N, Ansar A, Flyvbjerg B, Stevaux JC. 2017. Damming the rivers of the Amazon basin Nature 546:363-369.

Laurance WF, Sayer J, Cassman KG. 2014. Agricultural expansion and its impacts on tropical nature. Trends in Ecology \& Evolution 29:107-116.

Laurance WF, Sloan S, Weng L, Sayer JA. 2015. Estimating the environmental costs of Africa's massive "development corridors". Current Biology 25:3202-3208.

Lee RJ, Gorog AJ, Dwiyahreni A, Siwu S, Riley J, Alexander H, Paoli GD, Ramono W. 2005. Wildlife trade and implications for law enforcement in Indonesia: a case study from North Sulawesi. Biological Conservation 123:477-488.

Leendertz SAJ, Wich SA, Ancrenaz M, Bergl RA, Gonder MK, Humle T, Leendertz FH. 2017. Ebola in great apes - current knowledge, possibilities for vaccination, and implications for conservation and human health. Mammal Review 47:98-111. DOI:10.1111/mam.12082.

Lewis SL, Edwards DP, Galbraith D. 2015. Increasing human dominance of tropical forests. Science 349: 827-832.

Liengola I, Vosper A, Maisels F, Bonyenge A, Nkumu P. 2009. Conserving Bonobos in the last unexplored forest of the Democratic Republic of Congo - the Tshuapa-Lomami-Lualaba Landscape. Unpublished report, Wildlife Conservation Society. p10. New York, USA. 
1669

1670

1671

1672

1673

1674

1675

1676

1677

1678

1679

1680

1681

1682

1683

1684

1685

1686

1687

1688

1689

1690

1691

1692

1693

1694

1695

1696

1697

1698

1699

1700

1701

1702

1703

1704

1705

1706

1707

1708

1709

1710

1711

1712

1713

Lim FKS, Carrasco LR, McHardy J, Edwards DP. 2016. Perverse market outcomes from biodiversity conservation interventions. Conservation Letters E-pub ahead of print. https://doi.org/10.1111/conl.12332.

Longa CS, Bruno SF, Pires AR, Romijn PC, Kimura LS, Costa CHC. 2011. Human herpesvirus 1 in wild marmosets, Brazil, 2008. Emerging Infectious Diseases 17:1308-1310.

Longley, A., 2018. BofA sees oil demand Peaking by 2030 as electric vehicles boom, In Bloomberg Technology. Available at https://www.bloomberg.com/news/articles/2018-0122/bofa-sees-oil-demand-peaking-by-2030-as-electric-vehicles-boom.

Loucks C, Mascia MB, Maxwell A, Huy K, Duong K, Chea N, Long B, Cox N, Seng T. 2009. Wildlife decline in Cambodia, 1953-2005: Exploring the legacy of armed conflict. Conservation Letters 2:82-92.

Maisels F, Nkumu P, Bonyenge A. 2009. Salonga National Park, Democratic Republic of Congo: Terrestrial wildife and human impact monitoring programme. Survey ReportSalonga Corridor. Kinshasa, DRC: Wildlife Conservation Society.

Maldonado AM, Nijman V, Bearder SK. 2009. Trade in night monkeys Aotus spp. in the Brazil-Colombia-Peru tri-border area: international wildlife trade regulations are ineffectively enforced. Endangered Species Research 9:143-149.

Malhi Y, Roberts JT, Betts RA, Killeen TJ, Li W, Nobre CA. 2008. Climate change, deforestation, and the fate of the Amazon. Science 319:169-172.

Mancheri NA, Sprecher B, Deetman S, Young SB, Bleischwitz R, Dong L, Kleijn R, Tukker A. 2018. Resilience in the tantalum supply chain. Resources, Conservation and Recycling 129:56-69.

Margono AB, Turubanova S, Zhuravleva I, Potapov P, Tyukavina A, Baccini A, Goetz S, Hansen MC. 2012. Mapping and monitoring deforestation and forest degradation in Sumatra (Indonesia) using Landsat time series data sets from 1990 to 2010. Environmental Research Letters 7:1-16.

Mascia MB, Pailler S, Krithivasan R, Roshchanka V, Burns D, Mlotha MJ, Murray DR, Peng N. 2014. Protected area downgrading, downsizing, and degazettement (PADDD) in Africa, Asia, and Latin America and the Caribbean, 1900-2010. Biological Conservation 169:355-361.

McLennan MR, Spagnoletti N, Hockings KJ. 2017. The implications of primate behavioral flexibility for sustainable human-primate coexistence in anthropogenic habitats. International Journal of Primatology 38:105-121

McNeely JA. 2003. Conserving forest biodiversity in times of violent conflict. Oryx 37:142152.

Meijaard E, Buchori D, Hadiprakarsa Y, Utami-Atmoko SS, Nurcahyo A, Tjiu A, Prasetyo D, Nardiyono LC, Ancrenaz M, Abadi F, Antoni ING, Armayadi D, Dinato A, Ella PG, Indrawan TP, Kussaritano CM, Priyono CWP, Purwanto Y, Puspitasari D, Putra MSW, Rahmat A, Ramadani H, Sammy J, Siswanto D, Syamsuri M, Andayani N, Wu H, Wells JA, Mengersen K. 2011. Quantifying killing of orangutans and human-orangutan conflict in Kalimantan, Indonesia. PLOS ONE 6:DOI: 10.1371/journal.pone.0027491

Meijaard E, Nijman V. 2000. Distribution and conservation of the proboscis monkey (Nasalis larvatus) in Kalimantan, Indonesia. Biological Conservation 92:15-24

Meijaard E, Nijman V. 2003. Primate hotspots on Borneo: predictive value for general biodiversity and the effects of taxonomy. Conservation Biology 17:725-732. 
1714

1715

1716

1717

1718

1719

1720

1721

1722

1723

1724

1725

1726

1727

1728

1729

1730

1731

1732

1733

1734

1735

1736

1737

1738

1739

1740

1741

1742

1743

1744

1745

1746

1747

1748

1749

1750

1751

1752

1753

1754

1755

1756

1757

1758

1759

Meijaard E, Wich S, Ancrenaz M, Marshall A J. 2012. Not by science alone: Why orangutan conservationists must think outside the box. Annals of the New York Academy of Sciences 1249:29-44.

Melo, FR. 2016. How difficult and how important is to manage endangered species in the wild? In: XXVIth Congress of the International Primatological Society and 39th meeting of the American Society of Primatologists, 2016, Chicago, IL, USA. ASP/IPS 2016 Chicago Scientific Program. Chicago, USA: IPS and ASP, 2016. v. 1. p. 393-394.

Melo FR; Terribile LC, Oliveira G, Lima-Ribeiro MS, Strier KB. 2016. The efficiency of Atlantic forest conservation areas to preserve the Northern Muriquis (Brachyteles hypoxanthus) in a changing climate. In: XXVIth Congress of the International Primatological Society and 39th meeting of the American Society of Primatologists, 2016, Chicago, IL, USA. ASP/IPS 2016 Chicago Scientific Program. Chicago, USA: IPS and ASP, 2016. v.1. p.400.

Melo FR, Ferraz DS, Valença-Montenegro MM, Oliveira LC, Pereira DG, Port-Carvalho M. 2015. Avaliação do risco de extinção de Callithrix aurita (É. Geoffroy, 1812) no Brasil. Processo de avaliação do risco de extinção da fauna brasileira. ICMBio. Brazil. Website: http:// www.icmbio.gov.br/portal/biodiversidade/fauna-brasileira/estado-de conservacao/7198-mamiferos-callithrix-aurita-sagui-da-serra-escuro. html.

Merker S, Yustian I, Mühlenberg M. 2005. Responding to forest degradation: altered habitat use by Dian's tarsier Tarsius dianae in Sulawesi, Indonesia. Oryx 39: 189-195.

Meyer ALS, Pie MR, Passos FC. 2014. Assessing the exposure of lion tamarins (Leontopithecus spp.) to future climate change. American Journal of Primatology 76:551562.

Michon G, de Foresta H. 1995. The Indonesian agro-forest model. In: Halladay P, Gimour DA, eds. Conserving Biodiversity Outside Protected Areas: The Role of Traditional Agroecosystems. IUCN, Gland. 90-106.

Ministere des Hydrocarbures DRC 2013. Oil Exploration Concessons in the DRC. MapforEnvorinment. Available at, https://mapforenvironment.org/layer/info/184/\#4.17/$1.86 / 25.26$.

Mittermeier RA, Robles Gil P, Mittermeier CG. 1997. Megadiversity: Earth's Biologically Wealthiest Nations. (CEMEX, Mexico City, Mexico).

Mittermeier, RA, Fonseca GAB da, Rylands AB, Brandon K. 2005. A brief history of biodiversity conservation in Brazil. Conservation Biology 19:601-607.

Mittermeier RA, Louis Jr EE, Richardson M, Schwitzer C, Langrand O, Rylands AB, Hawkins F, Rajaobelina S, Ratsimbazafy J, Rasoloarison R, Roos C, Kappeler PM, Mackinnon J. 2010. Lemurs of Madagascar. Third edition. Conservation International, Washington, DC, USA.

Mockrin MH, Bennett EL, Labruna DT. 2005. Wildlife farming: a viable alternative to hunting in tropical forests? Wildlife Conservation Society, Bronx, NY. Available at https://library.wcs.org/DesktopModules/Bring2mind/DMX/Download.aspx?

Molinario G, Hansen MC, Potapov PV, Tyukavina A, Stehman S, Barker B, Humber M. 2017. Quantification of land cover and land use within the rural complex of the Democratic Republic of Congo. Environmental Research Letters 12:104001.

Molinario G, Hansen MC, Potapov PV. 2015. Forest cover dynamics of shifting cultivation in the Democratic Republic of Congo: a remote sensing-based assessment for 2000-2010. Environmental Research Letters 10:094009 DOI:10.1088/1748-9326/10/9/094009. 
1760

1761

1762

1763

1764

1765

1766

1767

1768

1769

1770

1771

1772

1773

1774

1775

1776

1777

1778

1779

1780

1781

1782

1783

1784

1785

1786

1787

1788

1789

1790

1791

1792

1793

1794

1795

1796

1797

1798

1799

1800

1801

1802

1803

1804

1805

Morgan D, Mundry R, Sanz C, Ayina CE, Strindberg S, Lonsdorf E, Kühl HS. 2017. African apes coexisting with logging: Comparing chimpanzee (Pan troglodytes troglodytes) and gorilla (Gorilla gorilla gorilla) resource needs and responses to forestry activities. Biological Conservation. https://doi.org/10.1016/j.biocon.2017.10.026.

Moore RS, Wihermanto, Nekaris KAI. 2014, Compassionate conservation, rehabilitation and translocation of Indonesian slow lorises. Endangered Species Research 26:93-102.

Moran D, Petersone M, Verones F. 2016. On the suitability of input-Output analysis for calculating product-specific biodiversity footprints. Ecological Indicators 60:192-201.

Murphy AJ, Ferguson B, Gardner CJ. 2017. Recent estimates of ring-tailed lemur (Lemur catta) population declines are methodologically flawed and misleading. International Journal of Primatology 38:24-34. DOI: 10.12691/aees-5-2-1.

Musibono DE, Kabangu F, Munzundu A, Kisangala M, Nsimanda I, Sinikuna M, Kileba A. 2010. Les différents traités environnementaux sont-ils appropriés pour les populations des pays en développement (Afrique)? VertigO - la revue électronique en sciences de l'environnement. Available at http://vertigo.revues.org/9398.

Nantha HS, Tisdell C. 2009. The orangutan-oil palm conflict: economic constraints and opportunities for conservation. Biodiversity and Conservation 18:487-502.

Nasi R, Taber A, Van Vliet N. 2011. Empty forests, empty stomachs? Bushmeat and livelihoods in the Congo and Amazon Basins. International Forestry Review 13:355-368.

Nater, A., Mattle-Greminger MP, Nurcahyo A, Nowak MG., de Manuel M, Desai T, Groves C, Pybus M, Sonay Tugce B, Roos C, Lameira AR., Wich SA., Askew J, DavilaRoss M, Fredriksson G, de Valles G, Casals F, Prado-Martinez J, Goossens B, Verschoor EJ, Warren KS., Singleton I, Marques DA., Pamungkas J, PerwitasariFarajallah D, Rianti P, Tuuga A, Gut IG., Gut M, Orozco-terWengel P, van Schaik CP, Bertranpetit J, Anisimova M, Scally A, Marques-Bonet T, Meijaard E, and Krützen M. 2017. Morphometric, behavioral, and genomic evidence for a new orangutan species. Current Biology 27:1-12.

Ndoye O, Chupezi Tieguhong J. 2004. Forest resources and rural livelihoods: The conflict between timber and non-timber forest products in the Congo Basin. Scandinavian Journal of Forest Research. 19:1-9.

Nekaris KAI, Shepherd CR, Starr CR, Nijman V. 2010. Exploring cultural drivers for wildlife trade via an ethnoprimatological approach: a case study of slender and slow lorises (Loris and Nycticebus) in South and Southeast Asia. American Journal of Primatology 72:877-886.

Nekaris KAI, Campbell N, Coggins T G, Rode EJ, Nijman V. 2013. Tickled to death: Analysing public perceptions of 'cute' videos of threatened species (slow lorisesNycticebus spp.) on Web 2.0 sites. PLoS ONE 8: DOI: 10.1371/journal.pone.0069215.

Nekaris KAI. 2016. The Little Fireface Project: Community conservation of Asia's slow lorises via ecology, education, and empowerment. In: Waller M, ed. Ethnoprimatology. Developments in Primatology: Progress and Prospects Springer International Publishing, 259-272.

Nekaris KAI, McCabe S, Spaan D, Ali MI, Nijman V. 2018. A novel application of cultural consensus models to evaluate conservation education programs. Conservation Biology 32:466-476 DOI:10.1111/cobi.13023.

Nellemann C, Redmond I, Refisch J (eds.). 2010. The Last Stand of the Gorilla environmental Crime and Conflict in the Congo Basin. A Rapid Response Assessment. 
1806

1807

1808

1809

1810

1811

1812

1813

1814

1815

1816

1817

1818

1819

1820

1821

1822

1823

1824

1825

1826

1827

1828

1829

1830

1831

1832

1833

1834

1835

1836

1837

1838

1839

1840

1841

1842

1843

1844

1845

1846

1847

1848

1849

1850

1851

1852

Birkeland Trykkeri AS, United Nations Environment Programme, Norway. Available at http://staging.unep.org/pdf/GorillaStand_screen.pdf

Nepstad D, McGrath D, Stickler C, Alencar A, Azevedo A, Swette B, Bezerra T, DiGiano M, Shimada J, Seroa da Motta R, Armijo E, Castello L, Brando P, Hansen MC, McGrath-Horn M, Carvalho O, Hess L. 2014. Slowing Amazon deforestation through public policy and interventions in beef and soy supply chains. Science 344:11181123.

Neudert R, Ganzhorn J, Wätzold F. 2016. Global benefits and local costs - The dilemma of tropical forest conservation: A review of the situation in Madagascar Environmental Conservation 44: 82-96

Neumayer, E. 2001. Greening Trade and Investment: Environmental Protection without Protectionism, London: Earthscan Publication LTD, London and Sterling, VA. ISBN 1853837881.

Neumayer, E. 2017. Environment and trade. In: International Encyclopedia of Geography. Wiley Press. DOI: 10.1002/9781118786352.wbieg0037

Newmark WD, Jenkins CN, Pimm SL, McNeally PB, Halley JM. 2017. Targeted habitat restoration can reduce extinction rates in fragmented forests. Proceedings of the National Academy of Siences 114:9635-9640 DOI:10.1073/pnas.1705834114.

Nijman V. 2009. An assessment of trade in gibbons and orang-utans in Sumatra, Indonesia. Kuala Lumpur. TRAFFIC Southeast Asia. www.trafficj.org/publication/09_Assessment_Trade_Gibbons_Orang-utans.pdf

Nijman V, Martinez CFY, Shepherd CR. 2009. Saved from trade: donated and confiscated gibbons in zoos and rescue centres in Indonesia. Endangered Species Research 9:151-157.

Nijman V, Nekaris KAI, Donati G, Bruford MW, Fa J. 2011. Primate conservation: Measuring and mitigating trade in primates. Endangered Species Research 13:159-161.

Nijman V, Spaan D, Rode-Margono EJ, Nekaris KAI. 2017. Changes in the primate trade in Indonesian wildlife markets over a 25-year period: Fewer apes and langurs, more macaques, and slow lorises. American Journal of Primatology 79:e22517 DOI: 10.1002/ajp.22517.

Nijman V. 2017. Orangutan trade, confiscations, and lack of prosecutions in Indonesia. American Journal of Primatology 79:e22652 DOI: 10.1002/ajp.22652.

Nlandu Mayamba T. 2012. Mapping Police Services in the Democratic Republic of Congo: Institutional Interactions at Central, Provincial and Local Levels. Institute of Development Studies Research Reports: Institute of Development Studies. p 103. Avaialable at https://www.ids.ac.uk/files/dmfile/rr71.pdf

Nogueira DM, Ferreira AMR, Goldschmidt B, Pissinatti A, Carelli JB, Verona CE. 2011. Cytogenetic study in natural hybrids of Callithrix (Callitrichidae: Primates) in the Atlantic forest of the state of Rio de Janeiro, Brazi. Iheringia: Série Zoologia 101:156-160.

Norris D, Rocha-Mendes F, Marques R, Almeida Nobre R, Galetti M. 2011. Density and spatial distribution of buffy-tufted-ear marmosets (Callithrix aurita) in a continuous Atlantic forest. International Journal of Primatology 32:811-829.

Nunn CL, Altizer S. 2006. Infectious diseases in primates: behavior, ecology and evolution. Oxford University Press, Oxford.

Nunn CL, Gillespie TR. 2016. Infectious disease and primate conservation. In: Wich SA, Marshall AJ, eds. An introduction to primate conservation. Oxford University Press, 157173.

Nuñez-Iturri G, Olsson O, Howe HF. 2008. Hunting reduces recruitment of primate-dispersed trees in Amazonian Peru. Biological Conservation 141:1536-1546. 
1853

1854

1855

1856

1857

1858

1859

1860

1861

1862

1863

1864

1865

1866

1867

1868

1869

1870

1871

1872

1873

1874

1875

1876

1877

1878

1879

1880

1881

1882

1883

1884

1885

1886

1887

1888

1889

1890

1891

1892

1893

1894

1895

1896

1897

1898

Oboh VU, Tsue PT. 2010. Awareness of HIV/AIDS pandemic among rural farmers in Vandeikya Local Government Area of Benue State, Nigeria. Studies on Ethno-Medicine 4:183-189.

Overbeck, GE, Bergallo C, Grelle CEV, Freddy Bravo AA, Colli GR, Magnusson WE, Moraes W, Wilson Fernandes TG. 2018. Global biodiversity threatened by science budget cuts in Brazil. BioScience 68:11-12.

Oliveira PP, Grativol AD, Ruiz-Miranda CR. 2008. Conservação do mico-leão-dourado: enfrentando os desafios de uma paisagem fragmentada. Associação Mico-Leão-Dourado \& Editora da UENF. Campos dos Goytacazes, Brazil. 1-199.

Oliveira LC, Grelle CEV. 2012. Introduced primate species of an Atlantic Forest region in Brazil: present and future implications for the native fauna. Tropical Conservation Science 5:112-120.

Pacheco LF, Simonetti JA. 2000. Genetic structure of a mimosoid tree deprived of its seed disperser, the spider monkey. Conservation Biology 14:1766-1775.

Paciulli LM. 2004. The effects of logging on the densities of the Pagai, Mentawai Island primates. American Journal of Physical Anthropology. Supplement 38:156.

Pedersen AB, Altizer S, Poss M, Cunningham AA, Nunn CL. 2005. Patterns of host specificity and transmission among parasites of wild primates. International Journal for Parasitology 35:647-657.

Pereira DG, Oliveira MEA, Ruiz-Miranda CR. 2008. Interações entre calitriquídeos exóticos e nativos no Parque Nacional daSerra dos Órgãos-RJ. Revista Espaço E Geografia 11:87114.

Peres CA. 1999. Ground fires as agents of mortality in a Central Amazonian forest. Journal of Tropical Ecology 15: 535-541.

Peres CA. 2001. The fire next time. The potential for a catastrophic blaze threatens the Amazon. Time magazine 8 January 2001, p.48.

Peres CA, Emilio TJ, Schietti S, Desmoulière JM, Levi T. 2016. Dispersal limitation induces long-term biomass collapse in overhunted Amazonian forests. Proceedings of the National Academy of Sciences 113:892-897.

Pigott DM, Golding N, Mylne A, Huang Z, Henry AJ, Weiss D, Brady OJ, Kraemer MUG, Smith DL, Moyes CL, Bhatt S, Gething PW, Horby PW, Bogoch IA, Brownstein JS, Mekaru SR, Tatem AJ, Khan K, Hay SI. 2014. Mapping the zoonotic niche of Ebola virus disease in Africa. elife, 04395.

Pigott DM, Millear AI, Earl L, Morozoff C, Han BA, Shearer FM, Weiss D, Brady OJ, Kraemer MUG, Moyes CL, Bhatt S, Gething PW, Golding N, Hay SI. 2016. Updates to the zoonotic niche map of Ebola virus disease in Africa. elife 5, e16412.

Plumptre AJ, Nixon S, Critchlow R, Vieilledent G, Nishuli R, Kirkby A, Williamson EA, Hall JS \& Kujirakwinja D. 2015. Status of Grauer's Gorilla and Chimpanzees in Eastern Democratic Republic of Congo: Historical and Current Distribution and Abundance. Wildlife Conservation Society, Fauna \& Flora International and Institut Congolais pour la Conservation de la Nature, New York. Available at http:/www.albertinerift.org/aboutus/publications.aspx

Plumptre, A., Nixon, S., Caillaud, D., Hall, J.S., Hart, J.A., Nishuli, R. \& Williamson, E.A. 2016a. Gorilla beringei ssp. graueri. The IUCN Red List of Threatened Species.

Plumptre, A., Hart, J.A., Hicks, T.C., Nixon, S., Piel, A.K. \& Pintea, L. 2016b. Pan troglodytes ssp. schweinfurthii. The IUCN Red List of Threatened Species. 
1899

1900

1901

1902

1903

1904

1905

1906

1907

1908

1909

1910

1911

1912

1913

1914

1915

1916

1917

1918

1919

1920

1921

1922

1923

1924

1925

1926

1927

1928

1929

1930

1931

1932

1933

1934

1935

1936

1937

1938

1939

1940

1941

1942

1943

1944

Plumptre AJ, Nixon S, Kujirakwinja DK, Vieilledent G, Critchlow R, Williamson EA, Nishuli R, Kirkby AE, Hall, JS. 2016c. Catastrophic decline of world's largest primate: $80 \%$ loss of Grauer's gorilla (Gorilla beringei graueri) population justifies Critically Endangered status. PLoS ONE 11:e0162697. DOI:10.1371/journal.pone.0162697.

Plumptre A, Robbins M, Williamson EA. 2016d. Gorilla beringei. The IUCN Red List of Threatened Species 2016.

Porter-Bolland L, Ellis EA, Guariguata MR, Ruiz-Mallén I, Negrete-Yankelevich S, ReyesGarcía V. 2012. Community managed forests and forest protected areas: An assessment of their conservation effectiveness across the tropics. Forest Ecology and Management 268:617.

Port-Carvalho M, Kierulff MCM. 2009. Callithrix aurita (É. geoffroy, 1812) primates, callitrichidae. In: Bressan PM, Kierulff MCM, Sugieda AM, eds. Fauna Ameaçada de Extinção no Estado de São Paulo: Vertebrados (Vol. 1). São Paulo: Fundação Parque Zoológico de São Paulo e Secretaria do Meio Ambiente.

Potapov P, Yaroshenko A, Turubanova S, Dubinin M, Laestadius L, Thies C, Aksenov D, Egorov A, Yesipova Y, Glushkov I, Karpachevskiy M, Kostikova A, Manisha A, Tsybikova E, Zhuravleva I. 2008. Mapping the world's intact forest landscapes by remote sensing. Ecology and Society 13:51 Available at http://www.ecologyandsociety.org/vol13/iss2/art51/

Potapov P, Hansen MC, Yaroshenko A, Minnemeyer S, Thies C, Esipova E, Laestadius L, Smith W, Turubanova S, Zhuravleva I, Komarova A. 2017. The last frontiers of wilderness: Tracking loss of intact forest landscapes from 2000 to 2013. Science Advances 3:e1600821.

PRODES, 2018. http://www.obt.inpe.br/prodes/dashboard/prodes-rates.html

Quinten MF, Stirling S, Schwarze Y, Dinata K, Hodges K. 2014. Knowledge, attitudes and practices of local people on Siberut Island (West-Sumatra, Indonesia) towards primate hunting and conservation. Journal of Threatened Taxa 6:6389-6398; DOI: 10.11609/jot.03963.6389-98.

Raboy B, Neves L, Zeigler S, Saraiva N, Cardoso N, Santo G, Ballou J, Leimgruber P. 2010. Strength of habitat and landscape metrics in predicting golden-headed lion tamarin presence or absence in forest patches. Biotropica 42:388-397.

Rambaldi DM, Kleiman DG, Mallinson JJC, Dietz LA, Padua SM. 2008. O papel das Organizações Não-Governamentais e do Comitê Internacional para a Conservação e Manejo de Leontopithecus na conservação do mico-leão. In: Kleiman DG, Rylands AB, eds. Micosleões: biologia e conservação. Ministério do Meio Ambiente. Brasília, Brasil, 105-135.

Rambaldi DM, Baker AJ. 2012. The golden lion tamarin Leontopithecus rosalia: A conservation success story. International Zoo Yearbook. 46:36-45.

Randriamalala H, Liu Z. 2010. Rosewood of Madagascar: Between democracy and conservation. Madagascar Conservation and Development 5:12. DOI:10.4314/167.

Rasambainarivo FT, Gillespie TR, Wright PC, Arsenault J, Villeneuve A, Lair S. 2013. Survey of Giardia and Cryptosporidium in lemurs from the Ranomafana National Park, Madagascar. Journal of Wildlife Diseases 49:741-743.

Rasoamanarivo V, Raharivololona BM, Frasier CL, Ginter A, Andriamandimbisoa R, Randriamahefasoa R, Louis EE Jr. 2015. Anthropogenic pressures threatening the black and white ruffed lemur (Varecia variegate editorum) in the Analamazaotra Special Reserve, Madagascar. Lemur News 19:38-44. 
1945

1946

1947

1948

1949

1950

1951

1952

1953

1954

1955

1956

1957

1958

1959

1960

1961

1962

1963

1964

1965

1966

1967

1968

1969

1970

1971

1972

1973

1974

1975

1976

1977

1978

1979

1980

1981

1982

1983

1984

1985

1986

1987

1988

1989

1990

Rasolofoson RA, Ferraro PJ, Jenkins CN, Jones JP. 2015. Effectiveness of community forest management at reducing deforestation in Madagascar. Biological Conservation, 184:271277.

Rasolofoson RA, Ferraro PJ, Ruta, G., Rasamoelina, M.S., Randriankolona, P.L., Larsen, H.O. and Jones, J.P., 2017. Impacts of community forest management on human economic well-being across Madagascar. Conservation Letters 10:346-353.

Razafimanahaka JH, Jenkins RK, Andriafidison D, Randrianandrianina F, Rakotomboavonjy V, Keane A, Jones JP. 2012. Novel approach for quantifying illegal bushmeat consumption reveals high consumption of protected species in Madagascar. Oryx, 46:584-592.

Reuter KE, Gilles H, Wills AR, Sewall BJ. 2016. Live capture and ownership of lemurs in Madagascar: extent and conservation implications. Oryx, 50:344-354.

Reuter KE, Schaefer MS. 2016. Captive conditions of pet lemurs in Madagascar. Folia Primatologica 87:48-63.

Rezende GC. 2014. Mico-leão-preto: a história de sucesso na conservação de uma espécie ameaçada. Matrix. São Paulo, Brasil. 1-176.

Ribeiro MC, Metzger JP, Martensen AC, Ponzoni FJ, Hirota MM. 2009. The Brazilian Atlantic Forest: How much is left, and how is the remaining forest distributed? Implications for conservation. Biological Conservation 142:1141-1153.

Rittera CD., McCratec G, Nilssona RH, Fearnsided PM, Palmef U, Antonellia A. 2017. Environmental impact assessment in Brazilian Amazonia: Challenges and prospects to assess biodiversity. Biological Conservation 206:161-168.

Robbins MM, Gray M, Fawcett KA, Nutter FB, Uwingeli P, Mburanumwe I, Kagoda E, Basabose A, Stoinski TS, Cranfield MR, Byamukama J, Spelman LH, Robbins AM. 2011. Extreme conservation leads to recovery of the Virunga Mountain Gorillas. PLoS One 6:e19788.

Robinson JG, Bennett EL. 2000. Hunting for sustainability in tropical forests. Columbia University Press, New York. p. 582.

Rovero F, Mtui AS, Kitegile AS, Nielsen MR. 2012. Hunting or habitat degradation? Decline of primate populations in Udzungwa Mountains, Tanzania: An analysis of threats. Biological Conservation 146:89-96.

Rovero F, Mtui A, Kitegile A, Jacob P, Araldi A, Tenan S. 2015. Primates decline rapidly in unprotected forests: Evidence from a monitoring program with data

Ruiz-Miranda CR, Affonso, Morais MM, Verona CES, Martins A, Beck BB. 2006. Behavioral and ecological interactions between reintroduced golden lion tamarins (Leontopithecus rosalia Linnaeus, 1766) and introduced marmosets (Callithrix spp, Linnaeus, 1758) in Brazil's Atlantic Coast Forest fragments. Arquivos de Biologia e Tecnologia 49:99-109.

Runting, RK, Meijaard E, Abram NK, Wells JA, Gaveau DLA, Ancrenaz M, Possingham HP, Wich SA, Ardiansyah F, Gumal MT, Ambu LN, Wilson KA. 2015. Alternative futures for Borneo show the value of integrating economic and conservation targets across borders. Nature Communications DOI:10.1038/ncomms7819.

Rylands AB. 1990. Priority areas for conservation in Amazonia. Trends in Ecology and Evolution 5:240-241.

Rylands AB. Huber O. Brown Jr. KS. 1991. Workshop-90, Biological Priorities for Conservation in Amazonia. Map scale 1:5,000,000. Instituto Brasileiro do Meio-Ambiente e 
1991

1992

1993

1994

1995

1996

1997

1998

1999

2000

2001

2002

2003

2004

2005

2006

2007

2008

2009

2010

2011

2012

2013

2014

2015

2016

2017

2018

2019

2020

2021

2022

2023

2024

2025

2026

2027

2028

2029

2030

2031

2032

2033

2034

2035 dos Recursos Naturais Renováveis (Ibama), Brasília, Instituto Nacional de Pesquisas da Amazônia (INPA), Manaus, and Conservation International, Washington, DC.

Rylands AB., Brandon K. 2005. Brazilian protected areas. Conservation Biology 19:612-618. Rylands AB, Strier KB, Mittermeier RA, Borovansky J, Seal US. 1998. Population and Habitat Viability Assessment (PHVA) for the Muriqui (Brachyteles arachnoides). IUCN/SSC Conservation Breeding Specialist Group (CBSG). Apple Valley, USA. 1-122.

Salafsky N. 1993. Mammalian use of a buffer zone agroforestry system bordering Ganung Palung National Park, West Kalimantan, Indonesia. Conservation Biology 7:928-933.

Santika T, Ancrenaz M, Wilson KA, Spehar S, Abram N, Banes GL, Campbell-Smith G, Curran L, d'Arcy L, Delgado RA, Erman A, Goossens B, Hartanto H, Houghton M, Husson SJ, Kühl HS, Lackman I, Leiman A, Sanchez KL, Makinuddin N, Marshall AJ, Meididit A, Mengersen K, Musnanda, Nardiyono, Nurcahyo A, Odom K, Panda A, Prasetyo D, Purnomo, Rafiastanto A, Raharjo S, Ratnasari D, Russon AE, Santana AH, Santoso E, Sapari I, Sihite J, Suyoko A, Tjiu A, Utami-Atmoko SS, van Schaik CP, Voigt M, Wells J, Wich SA, Willems EP, Meijaard E. 2017a. First integrative trend analysis for a great ape species in Borneo. Scientific Reports Available at https://www.nature.com/articles/s41598-017-04435-9.pdf

Santika T, Meijaard E, Budiharta S, Law EA, Kusworo A, Hutabarat JA, Indrawan TP, Struebig M, Raharjo S, Huda I, Ekaputri AD. 2017b. Community forest management in Indonesia: Avoided deforestation in the context of anthropogenic and climate complexities. Global Environmental Change 46:60-71.

Schillaci MA, Jones-Engel L, Engel GA \& Kyes RC. 2006. Exposure to human respiratory viruses among urban performing monkeys in Indonesia. American Journal of Tropical Medicine and Hygiene 75:716-719.

Schloss A, Nuñez TA, Lawler JJ. 2012. Dispersal will limit ability of mammals to track climate change in the Western Hemisphere. Proceedingss of the National Academy of Sciences. U.S.A. 109:8606-8611.

Schwitzer N, Clough D, Zahner H, Kaumanns W, Kappeler P, Schwitzer C. 2010. Parasite prevalence in blue-eyed black lemurs Eulemur flavifrons in differently degraded forest fragments. Endangered Species Research 12:215-225.

Schwitzer C, King T, Robsomanitrandrasana E, Chamberlan C, Rasolofoharivelo T. 2013. Integrating Ex situ and in situ Conservation of Lemurs. In: Schwitzer C, Mittermeier RA, Davies N, Johnson S, Ratsimbazafy J, Razafindramanana J, Louis Jr. EE, Rajaobelina S, eds. Lemurs of Madagascar: A Strategy for Their Conservation 2013-2016. Bristol, UK: IUCN SSC Primate Specialist Group, Bristol Conservation and Science Foundation, and Conservation International, 146-152.

Schwitzer C, Mittermeier RA, Johnson SE, Donati G, Irwin M, Peacock H, Ratsimbazafy J, Razafindramanana J, Louis EE, Chikhi L, Colquhoun IC. 2014. Averting lemur extinctions amid Madagascar's political crisis. Science 343:842-843.

Semroc B, Thomas M, Ward J, Buchanan J. 2015. Incentivizing No-Deforestation Palm Oil Production in Liberia and the Democratic Republic of Congo. Washington, D.C., USA: USAID-supported Forest Carbon, Markets and Communities Program. p 58.

Setiawan A, Wibisono Y, Nugroho TS, Agustin IY, Imron MA, Pudyatmoko S. Javan Surili. 2010. A survey population and distribution in Mt. Slamet Central Java, Indonesia. Journal Primatologi Indonesia 7:51-54. 
2036

2037

2038

2039

2040

2041

2042

2043

2044

2045

2046

2047

2048

2049

2050

2051

2052

2053

2054

2055

2056

2057

2058

2059

2060

2061

2062

2063

2064

2065

2066

2067

2068

2069

2070

2071

2072

2073

2074

2075

2076

2077

2078

2079

2080

2081

Setiawan A, Nugroho TS, Wibisono Y, Ikawati V, SUGARDJITO J. 2012. Population density and distribution of Javan gibbon (Hylobates moloch) in Central Java, Indonesia. Biodiversitas Journal of Biological Diversity. 1:23-27.

Shanee N, Mendoza AP, Shanee S. 2015. Diagnostic overview of the illegal trade in primates and law enforcement in Peru. American Journal of Primatology. 79:DOI: 10.1002/ajp.22516.

Sharif AM, Saha N. 2017. Conservation benefits of tropical multifunctional land-uses in and around a forest protected area of Bangladesh. Land 6:DOI: 10.3390/land6010002.

Shekelle, M, Salim A. 2009. An acute conservation threat to two tarsier species in the Sangihe Island chain, North Sulawesi, Indonesia. Oryx, 43:419-426.

Shepherd CR. 2010. Illegal primate trade in Indonesia exemplified by surveys carried out over a decade in North Sumatra. Endangered Species Research 11:201-205.

Simmen B, Bayart F, Marez A, Hladik A. 2007. Diet, nutritional ecology, and birth season of Eulemur macaco in an anthropogenic forest in Madagascar. International Journal of Primatology 28:1253-1266.

Soedarmanto I, Pasaribu FH, Wibawan IWT \& Lämmler C. 1996. Identification and molecular characterization of serological group C Streptococci isolated from diseased pigs and monkeys in Indonesia. Journal of Clinical Microbiology 34:2201-2204.

Sonter LJ, Herrera D, Barrett DJ, Galford GL, Moran CJ, Soares-Filho BS. 2017. Mining drives extensive deforestation in the Brazilian Amazon. Nature Communications 8:1013.

Spira C, Kirkby A, Kujirakwinja D, Plumptre AJ. 2017. The socio-economics of artisanal mining and bushmeat hunting around protected areas: Kahuzi-Biega National Park and Itombwe Nature Reserve, eastern Democratic Republic of Congo. Oryx Available at https://doi.org/10.1017/S003060531600171X.

Spracklen BD, Kalamandeen M, Galbraith D, Gloor E, Spracklen DV. 2015. A global analysis of deforestation in moist tropical forest protected areas. PLoS ONE 10:e0143886.

Stevenson PR, Aldana AM. 2008. Potential effects of ateline extinction and forest fragmentation on plant diversity and composition in the western Orinoco Basin, Colombia. Internation Journal of Primatology 29:365-377.

Stiles D. 1998. The Mikea hunter-gatherers of southwest Madagascar: Ecology and socioeconomics. African Studies Monographs 19:127-148.

Strassburg BBN, Brooks T, Feltran-Barbieri R, Iribarrem A, Crouzeilles R, Loyola R, Latawiec AE, Oliveira Filho FJB, Scaramuzza CAdeM, Scarano FR, Soares-Filho B, Balmford A.2017. Moment of truth for the Cerrado hotspot. Nature Ecology and Evolution 1:1-3.

Strier KB. 2007. Faces na Floresta. Sociedade para a Preservação do Muriqui - Preserve Muriqui. Rio de Janeiro, Brail. 1-190.

Strier KB, Possamai CB, Tabacow FP, Pissinatti A, Lanna AM, Rodrigues de Melo F, Moreira L, Tlebi M, Breves, P, Mendes SL, Jerusalinsky L. 2017. Demographic monitoring of wild muriqui populations: Criteria for defining priority areas and monitoring intensity. PloS ONE 12: 0188922.

Strindberg S, Maisels F, Williamson EA, Blake S, Stokes EJ, Aba'a R, Abitsi G, Agbor A, Ambahe RD, Bakabana PC, Bechem M, Berlemont A, Bokoto de Semboli B, Boundja PR, Bout N, Breuer T, Campbell G, De Wachter P, Ella Akou M, Esono Mba F, Feistner ATC, Fosso B, Fotso R, Greer D, Inkamba-Nkulu C, Iyenguet CF, Jeffery KJ, Kokangoye M, Kühl HS, Latour S, Madzoke B, Makoumbou C, Malanda G-AF, Malonga R, Mbolo V, Morgan DB, Motsaba P, Moukala G. Mowawa BS, Murai M, 
Ndzai C, Nishihara T, Nzooh Z, Pintea L, Pokempner A, Rainey HJ, Rayden T, Ruffler H, Sanz CM, Todd A, Vanleeuwe H, Vosper A, Warren Y, Wilkie DS. 2018. Guns, germs, and trees determine density and distribution of gorillas and chimpanzees in Western Equatorial Africa. Science Advances 4:eaar2964.

Struebig MJ, Fischer M, Gaveau DL, Meijaard E, Wich SA, Gonner C, Sykes R, Wilting A, Kramer-Schadt S. 2015. Anticipated climate and land-cover changes reveal refuge areas for Borneo's orang-utans. Global Change Biology 21:2891-2904.

Supriatna J, Dwiyahreni AA, Winarni N, Mariati S, Margules C. 2017. Deforestation of primate habitat on Sumatra and adjacent islands, Indonesia. Primate Conservation 31:71-82.

Supriatna J, Ario A. 2015. Primates as flagships for conserving biodiversity and parks in Indonesia: Lessons learned from West Java and North Sumatra. Primate Conservation 29:123-131.

Svensson MS, Ingram DJ, Nekaris KAI, Nijman V. 2015. Trade and ethnozoological use of African lorisiforms in the last 20 years. Hystrix, the Italian Journal of Mammalogy 26:153161.

Svensson, MS, Shanee S, Shanee N, Bannister FB, Cervera L, Donati G, Huck M, Jerusalinsky L, Juarez, CP, Maldonado AM, Mollinedo JM. Méndez-Carvajal PG, Molina Argandoña MA, Mollo Vino AD, Nekaris KA, Peck M, Rey-Goyeneche J, Spaan D, Nijman V. 2016. Disappearing in the night: An overview on trade and legislation of night monkeys in South and Central America. Folia Primatologica 87:332-348.

Talebi MG, Melo FR, Dias LG, Cunha AA, Mendes SL, Breves P, Jerusalinsky L. 2011. Contextualização sobre Brachyteles arachnoides e Brachyteles hypoxanthus. In: Jerusalinsky L, Talebi M, Melo FR, eds. Plano de Ação Nacional para a conservação dos muriquis. Instituto Chico de Conservação da Biodiversidade - ICMBio, Série Espécies Ameaçadas no 11. Brasília, Brasil. 16-61.

Tanentzap AJ, Lamb A, Walker S, Farmer A. 2015. Resolving conflicts between agriculture and the natural environment. PLoS Biology 13:e1002242.

Taubert F, Fischer R, Groeneveld J, Lehmann S, Müller MS, Rödig E, Eigan T, Huth A. 2018. Global patterns of tropical forest fragmentation. Nature DOI: 10.1038 /Nature 25508.

Tranquilli S, Abedi-Lartey M, Amsini F, Arranz L, Asamoah A, Babafemi O, Barakabuye N, Campbell G, Chancellor R, Davenport TRB, Dunn A, Dupain J, Ellis C, Etoga G, Furuichi T, Gatti S, Ghiurghi A, Greengrass E, Hashimoto C, Hart J, Herbinger I, Hicks TC, Holbech LH, Huijbregts B, Imong I, Kumpel N, Maisels F, Marshall P, Nixon S, Normand E, Nziguyimpa L, Nzooh-Dogmo Z, Tiku Okon D, Plumptre A, Rundus A, Sunderland-Groves J, Todd A, Warren Y, Mundry R, Boesch C, Kuehl H. 2012. Lack of conservation effort rapidly increases African great ape extinction risk. Conservation Letters 5:48-55.

Trefon T. 2009. Public Service Provision in a Failed State: Looking Beyond Predation in the Democratic Republic of Congo. Review of African Political Economy 36:9-21.

Trefon T. 2010. Administrative obstacles to reform in the Democratic Republic of Congo. International Review of Administrative Sciences 76:702-722.

Trefon T. 2013. Uncertainty and powerlessness in Congo 2012. Review of African Political Economy 40:141-151.

Trefon T. 2016. Congo's Environmental Paradox; Potential and Predation in a Land of Plenty. USA: Zed Books. 
2127

2128

2129

2130

2131

2132

2133

2134

2135

2136

2137

2138

2139

2140

2141

2142

2143

2144

2145

2146

2147

2148

2149

2150

2151

2152

2153

2154

2155

2156

2157

2158

2159

2160

2161

2162

2163

2164

2165

2166

2167

2168

2169

2170

2171

2172

Tilman, D, Clark M. 2014. Global diets link environmental sustainability and human ealth. Nature 515:518.

Tilman, D, Clark M, Williams DR, Kimmel K, Polasky S, Packer C. 2017. Future threats to biodiversity and pathways to their prevention. Nature 546: DOI: 10.1038/nature22900.

Timpe K, Kaplan D. 2017. The changing hydrology of a dammed Amazon. Science Advances 3:e1700611.

Trevelin LC, Port-Carvalho M, Silveira M, Morell E. 2007. Abundance, habitat use and diet of Callicebus nigrifrons Spix (primates, Pitheciidae) in Cantareira State Park, S ao Paulo, Brazil. Revista Brasileira do Zoologia 24:1071-1077.

Tscharntke T, Clough Y, Wanger TC, Jackson L, Motzke I, Perfecto I, Vandermeer J, Whitbread A. 2012. Global food security, biodiversity conservation and the future of agricultural intensification. Biological Conservation DOI: 10.1016/j.biocon.2012.01.068.

Tyukavina A, Stehman SV, Potapov PV, Turubanova SA, Baccini A, Goetz SJ, Laporte NT, Houghton RA, and Hansen MC. 2013. National-scale estimation of gross forest aboveground carbon loss: a case study of the Democratic Republic of the Congo. Environmental Research Letters 8: DOI:10.1088/1748-9326/8/4/044039.

UNESCO. 2006. Education for All: Literacy for Life. EFA Global Monitoring Report 2005, Paris.

UNFPA. 2007. State of world population 2007. Unleashing the potential of urban growth. New York: United Nations Population Fund. Available at https://www.unfpa.org/sites/default/files/pub-pdf/695_filename_sowp2007_eng.pdf.

UNODC. 2013. Transnational Organized Crime in East Asia and the Pacific. A Threat Assessment (United Nations Office on Drugs and Crime, Regional Office for Southeast Asia and the Pacific. Available at https://www.unodc.org/documents/data-andanalysis/Studies/TOCTA_EAP_web.pdf.

UNODC. 2016. United Nations Office on Drugs and Crime, World Wildlife Crime Report: Trafficking in Protected Species (United Nations Office on Drugs and Crime, 2016). Available at www.unodc.org/ documents/data-andanalysis/wildlife/World_Wildlife_Crime_Report_2016.

USDA Brazil Soya. 2017. World Agricultural Production. United States Department of Agriculture Foreign Agricultural Service Circular Series WAP 05-17 May 2017. Available at https://apps.fas.usda.gov/psdonline/circulars/production.pdf.

USAID. 2012. US Agency for International Development (US AID)/Central Africa Regional Program for the Environment (CARPE) Regional Development Cooperation Strategy 20122020, 1-38.

van Ginkel H. 2008. Urban future. Nature 456:32-33. DOI: 10.1038/twas08.32a.

Van Vliet N, Mesa MPQ, Cruz-Antia D, de Aquino LJN, Moreno J, Nasi R. 2014. The uncovered volumes of bushmeat commercialized in the Amazonian trifrontier between Colombia, Peru and Brazil. Ethnobiology and Conservation 3:1-11.

Van Vliet N, Nebesse, C, Gambalemoke S, Akaibe D, Nasi R. 2012. The bushmeat market in Kisangani, Democratic Republic of Congo: implications for conservation and food security. Oryx, 46:196-203.

Vasconcelos PFC. 2017. Yellow fever. In: Marcondes, CB, ed. Arthropod borne diseases. Springer, 101-113.

Veiga JB, Fortes VB, Bicca-Marques JC. 2014. Population viability analysis of a brown howler monkey metapopulation after an outbreak of yellow fever in southern Brazil. In: 
Abstracts of the XXV Congress of the International Primatological Society, Hanoi, Vietnam. 30.

Venter O, Koh LP. 2012. Reducing emissions from deforestation and forest degradation (REDD+): Game changer or just another quick fix? Annals of the New York Academy of Sciences 1249:137-150.

Venter O, Fuller RA, Segan DB, Carwardine J, Brooks T, Butchart SHM, Di Marco M, Iwamura T, Joseph L, O'Grady D, Possingham HP, Rondinini C, Smith RJ, Venter M, Watson JEM. 2014. Targeting global protected area expansion for imperiled biodiversity. PLoS Biology 12:e1001891.

Villoria NB, Golub A, Byerlee D, Stevenson J. 2013. Will yield improvements on the forest frontier reduce greenhouse gas emissions? A global analysis of oil palm. American Journal of Agricultural Economics 95:1301-1308.

Voigt M, Wich SA, Campbell-Smith G, Goossens B, Llano Sanchez K, Ancrenaz M, d'Arcy LJ, Heinicke S, Makinuddin N, Meijaard E, Delgado RD, Houghton M, Marshall AJ, Abram N, Erman A, Husson SJ, Meididit A, Banes GL, Gaveau D, Leiman A, Miettinen J. 2018. Global demand for natural resources eliminated more than 100,000 Bornean orangutans. Current Biology DOI: 10.1016/j.cub.2018.01.053.

Waeber PO, Wilmé L, Mercier J-R, Camara C, Lowry PP II. 2016. How effective have thirty years of internationally driven conservation and development efforts been in Madagascar? PLoS ONE 11:e0161115. DOI: 10.1371/journal.pone.0161115

Warren-Thomas E, Dolman PM, Edwards DP. 2015. Increasing demand for natural rubber necessitates a robust sustainability initiative to mitigate impacts on tropical biodiversity. Conservation Letters 8:230-24.

Weng L, Boedhihartono AK, Dirks PHGM, Dixon J, Lubis MI, and Sayer JA. 2013. Mineral industries, growth corridors and agricultural development in Africa. Global Food Security 2:195-202.

Wetterberg GB., Jorge Pádua, MT, Castro CS de, Vasconcellos., JMC de. 1976. Uma análise de prioridades em conservação da natureza na Amazônia. Projeto de Desenvolvimento e Pesquisa Florestal (PRODEPEF), PNUD/FAO/IBDF/BRA-45, Série Técnica 8:63pp.

Wetterberg GB, Prance GT, Lovejoy TE. 1981. Conservation progress in Amazonia: a structural review. Parks 6:5-10.

Wich SA, Garcia-Ulloa J, Kühl HS, Humle T, Lee JSH, Koh LP. 2014. Will oil palm's homecoming spell doom for Africa's great apes? Current Biology 24:1659-1663.

Wich SA, Gaveau D, Abram N, Ancrenaz M, Baccini A, Brend S, Curran L, Delgado RA, Erman A, Fredriksson GM, Goossens B, Husson SJ, Lackman I, Marshall AJ, Naomi A, Molidena E, Nardiyono, Nurcahyo A, Odom K, Panda A, Purnomo, Rafiastanto A, Ratnasari D, Santana AH, Sapari I, van Schaik CP, Sihite J, Spehar S, Santoso E, Suyoko A, Tiju A, Usher G, Utami Atmoko SS, Willems EP, Meijaard E. 2012. Understanding the impacts of land-use policies on a threatened species: is there a future for the Bornean Orang-utan? PLoS ONE 7:e49142.

Wiederholt R, Post E. 2010. Tropical warming and the dynamics of endangered primates. Biology Letters 6:257-260.

Wilkie DS, Curran B, Tshombe R, Morelli GA. 1998. Managing bushmeat hunting in Okapi Wildlife Reserve, Democratic Republic of Congo. Oryx 32:131-144. 
2218

2219

2220

2221

2222

2223

2224

2225

2226

2227

2228

2229

2230

2231

2232

2233

2234

2235

2236

2237

2238

2239

2240

2241

2242

2243

2244

2245

2246

2247

2248

2249

2250

2251

2252

2253

2254

2255

2256

2257

2258

2259

Wilkie DS, Wieland M., 2015. Conserving and Eating Wildlife in Africa. WCS Working Papers 47,50 .

Wilkie DS, Wieland M, Boulet H, Le Bel S, van Vliet N, Cornelis D, BriacWarnon V, Nasi R, Fa JE. 2016. Eating and conserving bushmeat in Africa. African Journal of Ecology 54:402-414.

Wilson HB, Meijaard E, Venter O, Ancrenaz M, Possingham HP. 2014. Conservation strategies for orangutans: Reintroduction versus habitat preservation and the benefits of sustainably logged forest. PLoS One 9:e102174.

Winemiller K, McIntyre P, Castello L, Fluet-Chouinard E, Giarrizzo T, Nam S, Baird I, Darwall W, Lujan N, Harrison I, Stiassny ML, Silvano RA, Fitzgerald DB, Pelicice FM, Agostinho AA, Gomes LC, Albert JS, Baran E, Petrere MJr, Zarfl C, Mulligan M, Sullivan JP, Arantes CC, Sousa LM, Koning AA, Hoeinghaus DJ, Sabaj M, Lundberg JG, Armbruster J, Thieme ML, Petry P, Zuanon J, Torrente Vilara G, Snoeks J, Ou C, Rainboth W, Pavanelli CS, Akama A, van Soesbergen A, Saenz L. 2016. Balancing hydropower and biodiversity in the Amazon, Congo, and Mekong. Science 351:128-129.

Wolf C, Ripple WJ. 2017. Range contractions of the world's large carnivores. Royal Society Open Science 4:170052. DOI: 10.1098/rsos.170052.

World Bank. 2017. http://data.worldbank.org/country (accessed 11 January 2018)..

World Bank. 2016. The Cost of Fire: An Economic Analysis of Indonesia's 2015 Fire Crisis. Washington, DC: World Bank. Available at http://documents.worldbank.org/curated/en/776101467990969768/The-cost-of-fire-aneconomic-analysis-of-Indonesia-s-2015-fire-crisis.

Yanggen D, Angu K, Tchamou N. 2010. Landscape-Scale Conservation in the Congo Basin : Lessons Learned from the Central Africa Regional Program for the Environment (CARPE). Gland, Switzerland: IUCN.

Yanuar A. 2009. The population distribution and abundance of siamangs (Symphalangus syndactylus) and agile gibbons (Hylobates agilis) in West Central Sumatra, Indonesia. In: Whittaker D, Lappan S, eds. The Gibbons. Developments in Primatology: Progress and Prospects. Springer Press. 453-465.

Yustian, I. 2007. Ecology and conservation status of Tarsius bancanus saltator on Belitung Island, Indonesia. PhD thesis. Gottingen University, Gottingen.

Zelazowski P, Malhi Y, Huntingford C, Sitch S, Fisher JB. 2011. Changes in the potential distribution of humid tropical forests on a warmer planet. Philosophical Transactions of the Royal Society a-Mathematical Physical and Engineering Sciences 369:137-160.

Ziegler S, Fa JE, Wohlfart C, Streit B, Jacob S, Wegmann M. 2016. Mapping bushmeat hunting pressure in Central Africa. Biotropica 48:405-412.

Zimkus BM, Lawson LP, Barej MF, Barratt CD, Channing A, Dash KM, Dehling JM, Du Preez L, Gehring P-S, Greenbaum E, Gvoždík V, Harvey J, Kielgast J, Kusamba C, Nagy ZT, Pabijan M, Penner J, Rödel M-O, Vences M, Lötters S. 2017. Leapfrogging into new territory: How Mascarene ridged frogs diversified across Africa and Madagascar to maintain their ecological niche. Molecular Phylogenetics and Evolution 106:254-269. 


\section{Table $\mathbf{1}$ (on next page)}

Tree cover loss (30\% canopy cover) in Intact Forested Landscapes in Brazil, DRC, Indonesia and Madagascar for the period 2001-2016.

Source of data: Potapov et al., 2017. 
1

2

3

\begin{tabular}{|l|c|c|c|c|}
\hline & $\begin{array}{l}\text { Forest cover } \\
(>30 \% \text { canopy, } \\
\left.2000 ; \mathrm{km}^{2} \times 10\right)^{3)}\end{array}$ & $\begin{array}{l}\text { IFL area 2000 } \\
\left(\mathrm{km}^{2} \times 10^{3}\right)\end{array}$ & $\begin{array}{l}\text { \% of IFL of } \\
\text { country's forest } \\
\text { cover in 2000 }\end{array}$ & $\begin{array}{l}\text { Reduction 2000- } \\
2013(\%) \text { not } \\
\text { attributed to fire }\end{array}$ \\
\hline Madagascar & 170 & 17.2 & 10 & 18.5 \\
\hline Indonesia & 1610 & 359.2 & 22 & 10.8 \\
\hline Brazil & 5190 & 2476.1 & 48 & 6.2 \\
\hline DRC & 1992 & 643.9 & 32 & 4.2 \\
\hline
\end{tabular}

4 


\section{Table 2 (on next page)}

Major importing countries (50\% of exports) of trade commodities ( 99 categories and their subcategories e.g., frozen beef, arboreal and non-arboreal food and non-food crops, ores, oil, wood and others) produced by Brazil, DRC, Madagascar, and Indonesia.

Source of data: (http://www.trademap.org/ (accessed 10 December 2017)). International trade maps for the four countries for all exports and for specific commodities see Text S1. 
1

2

3

4

\begin{tabular}{|c|c|c|c|c|c|c|c|}
\hline & Brazil & & DRC & & Madagascar & & Indonesia \\
\hline & $\begin{array}{c}\% \text { volume } \\
\text { imported } \\
\text { by }\end{array}$ & & $\begin{array}{c}\% \text { volume } \\
\text { imported } \\
\text { by }\end{array}$ & & $\begin{array}{c}\% \text { volume } \\
\text { imported } \\
\text { by }\end{array}$ & & $\begin{array}{c}\% \text { volume } \\
\text { imported } \\
\text { by }\end{array}$ \\
\hline China & 19 & China & 46 & France & 24 & China & 19 \\
\hline USA & 13 & S. Arabia & 11 & USA & 13 & USA & 11 \\
\hline Argentina & 7 & & & Germany & 9 & Japan & 11 \\
\hline $\begin{array}{c}\text { The } \\
\text { Netherlands }\end{array}$ & 6 & & & China & 7 & India & 8 \\
\hline Germany & 3 & & & & & & \\
\hline Japan & 3 & & & & & & \\
\hline Total $\%$ & 50 & & 57 & & 53 & & 50 \\
\hline
\end{tabular}

5 


\section{Table 3(on next page)}

CITES trade from Indonesia, Brazil, DRC and Madagascar over the period 2006-2016 (data from 2016 incomplete).

Percentage of wild-caught in brackets. Importer refers to data as reported by the various importing countries; exporter refers to data reported by the exporting countries, here Indonesia, Brazil, DRC, and Madagascar. Source: https://trade.cites.org/ (accessed 15 August 2017). See Text S1. 
1

2

3

4

5

\begin{tabular}{|c|c|c|c|c|}
\hline Country & Indonesia & Brazil & DRC & Madagascar \\
\hline \multicolumn{5}{|l|}{ Live animals } \\
\hline Importer & $15,579(0.06)$ & $166(0)$ & $561(100)$ & $13(7.69)$ \\
\hline Exporter & $19,009(0.67)$ & $154(0)$ & $217(97.24)$ & $4(25.00)$ \\
\hline \multicolumn{5}{|l|}{$\begin{array}{l}\text { Bodies, } \\
\text { skeletons, skins }\end{array}$} \\
\hline Importer & $40(100)$ & $0(0)$ & $20(90.00)$ & $11(100)$ \\
\hline Exporter & $3(0)$ & $153(60.13)$ & $9(100)$ & $47(100)$ \\
\hline \multicolumn{5}{|l|}{ Specimens } \\
\hline Importer & $\begin{array}{c}51,743 \\
(12.65)\end{array}$ & $385(82.60)$ & $4,876(92.99)$ & $17,695(100)$ \\
\hline Exporter & $\begin{array}{l}73,780 \\
(33.06)\end{array}$ & $\begin{array}{c}2,449 \\
(60.76)\end{array}$ & $4,184(93.40)$ & $\begin{array}{r}10,805 \\
(99.96)\end{array}$ \\
\hline
\end{tabular}




\section{Table 4 (on next page)}

Land area, 2016 human population size, population density, and population growth rates in Brazil, Madagascar, Indonesia, and DRC.

Source: FAOStats http://www.fao.org/faostat/en; The World Bank.

http://data.worldbank.org/data-catalog/world-development-indicators (accessed 5 February 2018). 
1

2

3

4

\begin{tabular}{|l|c|c|c|c|}
\hline & Brazil & Madagascar & Indonesia & DRC \\
\hline Land area $\mathrm{km}^{2}$ & $8,515,767$ & 587,041 & $1,904,569$ & $2,344,858$ \\
\hline 2016 Population & $207,852,865$ & $25,566,097$ & $263,354,770$ & $80,071,935$ \\
\hline 2016 Population in urban areas & $82 \%$ & $34 \%$ & $52 \%$ & $39 \%$ \\
\hline 2016 Density (persons/ $\left.\mathrm{km}^{2}\right)$ & 25 & 44 & 145 & 36 \\
\hline $\begin{array}{l}\text { 2016 Population growth rate (\%) } \\
\text { FAO }\end{array}$ & 0.77 & 2.75 & 1.07 & 3.09 \\
\hline $\begin{array}{l}\text { 2016 Population growth rate (\%) } \\
\text { World Bank }\end{array}$ & 0.82 & 2.69 & 1.14 & 3.28 \\
\hline
\end{tabular}

5 


\section{Table 5 (on next page)}

The Global Peace Index ranking.

Ranking based on the values of the GPI of 163 countries. High values $=$ A higher ranking represents a more unfavorable condition for the three dimensions of the GPI. Sources: Global Peace Index http://economicsandpeace.org (accessed 10 October 2017); economic ranking: World Economic Outlook Database (https://www.imf.org/external/pubs/ft/weo/2017/01/weodata/index.aspx) (accessed 11 October 2017). 
1

2

3

4

\begin{tabular}{|c|c|c|c|}
\hline Country & $\begin{array}{c}\text { ODIC } \\
\text { rank }\end{array}$ & SSS & MILIT \\
\hline Brazil (8th economy) & 17 & 116 & 109 \\
\hline DRC (90th economy) & 153 & 127 & 107 \\
\hline Madagascar (134th economy) & 68 & 42 & 23 \\
\hline Indonesia (15th economy) & 92 & 44 & 14 \\
\hline
\end{tabular}

5

ODIC Ongoing Domestic and International Conflict, SSS Societal Safety and Security, MILIT Militarization 


\section{Table 6(on next page)}

The number and accumulated extent of protected areas in Brazil, Madagascar, Indonesia and DRC.

According to the Protected Planet Database of the UNEP-WCMC - WCPA , Brazil has approximately $29 \%$ of its land area protected and therefore has exceeded the United Nations Environmental Program's global goal for countries to set aside and protect $17 \%$ of their land as protected areas. The other three countries have not reached the $17 \%$ goal (https://www.protectedplanet.net/country/ID; http://www.drcprotectedareas.org/en/parap;[i] Waeber et al., 2016[i]). 
1

2

3

4

\begin{tabular}{|r|c|c|c|c|}
\hline & Brazil & Madagascar & Indonesia & DRC \\
\hline Protected areas & 2,190 & 221 & 646 & 90 \\
\hline $\mathrm{km}^{2}$ protected & $2,468,479$ & 71,000 & 226,249 & 260,000 \\
\hline Land area $\mathrm{km}^{2}$ & $8,515,767$ & 587,041 & $1,904,569$ & $2,344,858$ \\
\hline $\begin{array}{l}\text { \% of land area } \\
\text { protected }\end{array}$ & 29 & 12 & 12 & 13 \\
\hline
\end{tabular}

5 


\section{Figure 1}

The richness of species and IUCN species conservation and population status of primates in Brazil, the Democratic Republic of the Congo (DRC), Madagascar and Indonesia.

In the graph, the numbers below the names of the countries refer to the number of species used to calculate the percentages for species threatened and declining populations. Because population assessments are not available for all species, we focused on those for which recent information is available (Table S2). Source of data: IUCN Red List 2017-3 http://www.iucnredlist.org (accessed 5 February 2018).

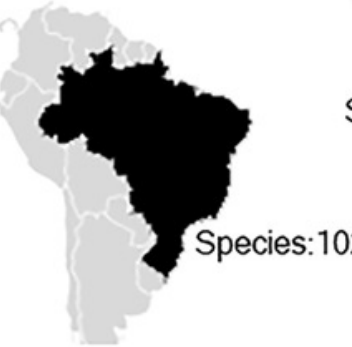

- Species threatened

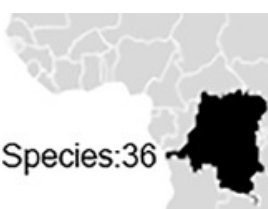

1

Species: 100

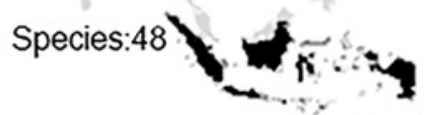

- Species with populations dedining

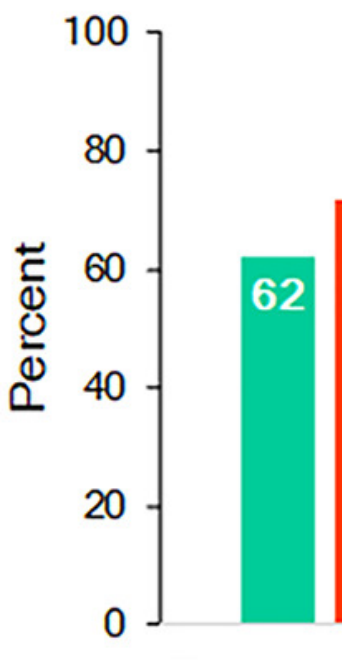

Four countries

$(176 / 172)$

\section{2}

\section{8}
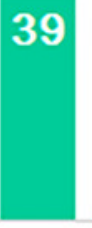

Brazil

$(40 / 49)$
93

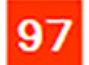

94

39

17

DRC

$(6 / 14)$
Madagascar

(97/97)
97

83
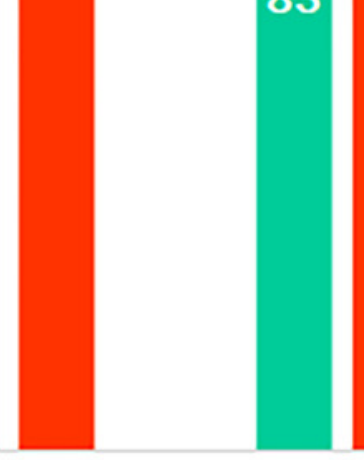

Indonesia

$(45 / 48)$ 


\section{Figure 2}

(A) Trends in tree cover loss ( $>30 \%$ canopy cover) in Brazil, DRC, Indonesia, and Madagascar for the period 2001-2016. (B) Cumulative tree cover (in Intact Forest Landscapes IFL) loss in each country for the same period.

Source of data Global Forest Watch http://www.globalforestwatch.org (accessed $5^{\text {th }}$ February 2018) IFL: an unbroken expanse of natural ecosystems of at least $500 \mathrm{~km} 2$, forested, and without signs of significant human activity (Potapov et al., 2008). Forest loss ranged in Brazil from 2.74 M ha in 2001 to $5.37 \mathrm{M}$ ha in 2016; in Indonesia from $745.43 \mathrm{~K}$ ha to $2.42 \mathrm{M}$ ha; in DRC from $455.43 \mathrm{~K}$ ha to $1.38 \mathrm{M}$ ha, and in Madagascar from $86.95 \mathrm{~K}$ ha to $383.55 \mathrm{~K}$ ha. 
(A)

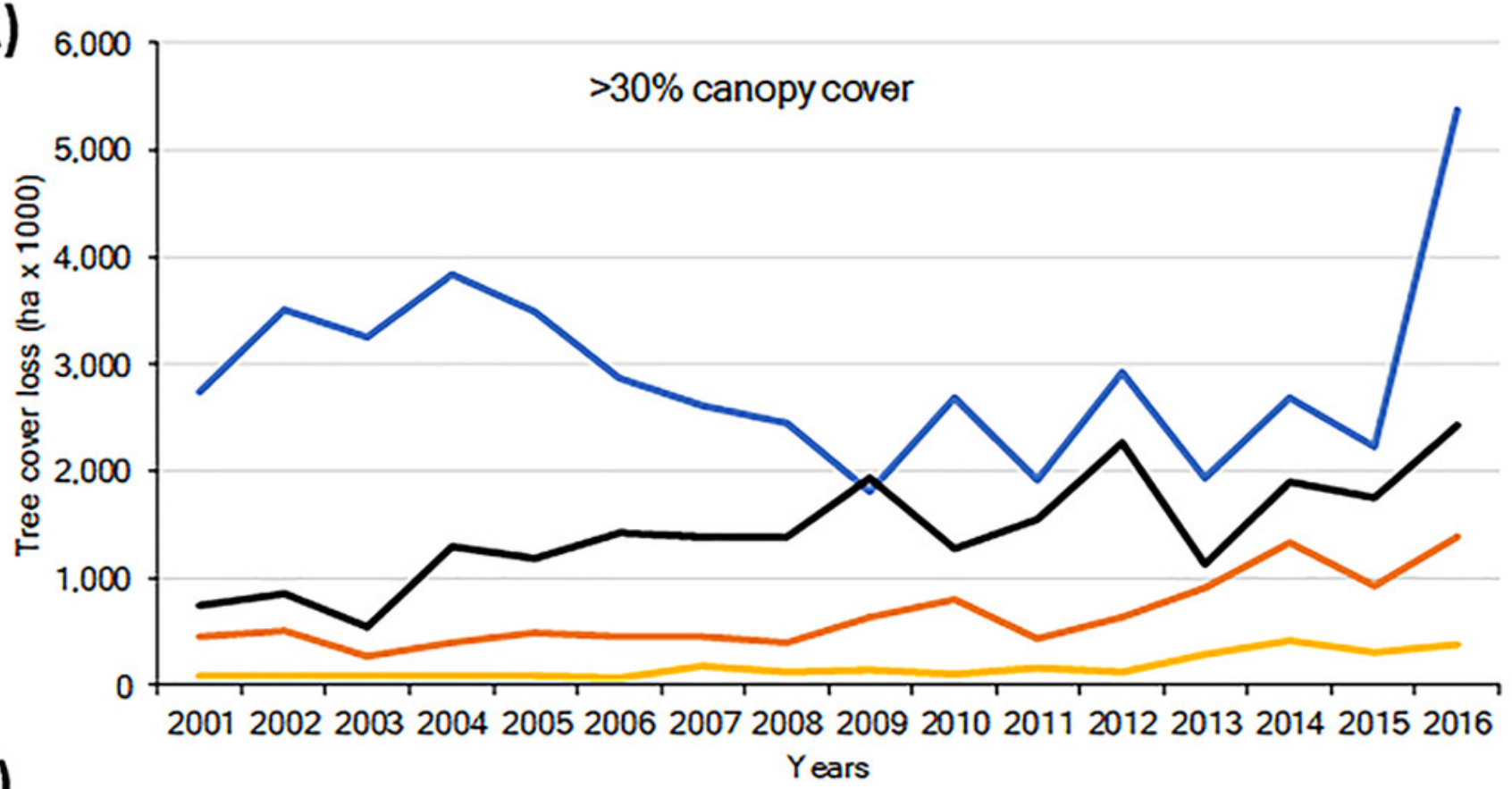

(B)

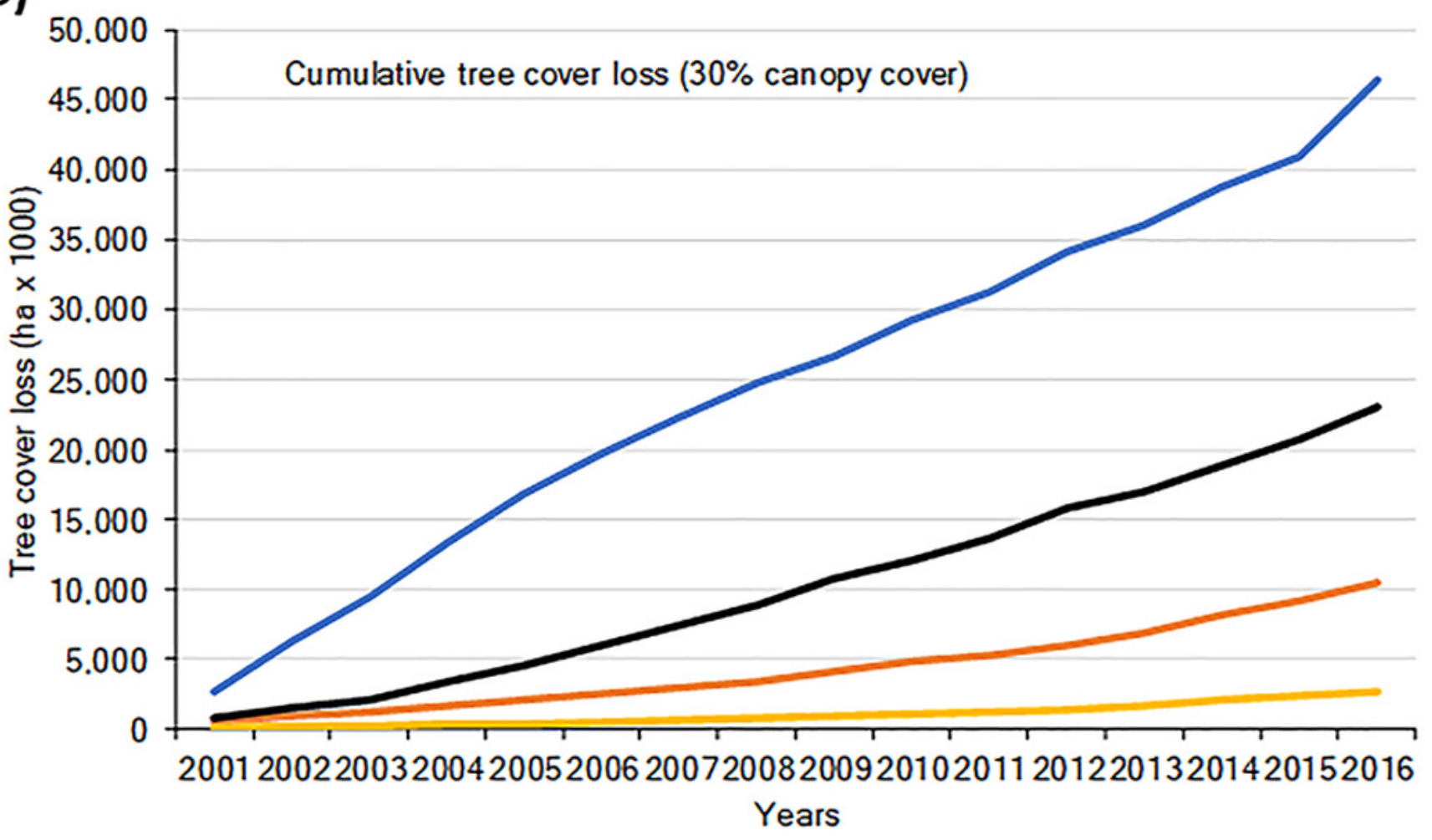

—Brazil —DRC —Indonesia — Madagascar 


\section{Figure 3}

The projected expansion of agriculture and pastures in (A) Brazil, (B) the Democratic Republic of the Congo, (C) Madagascar and (D) Indonesia for 2050 and 2100, under a worst-case scenario of land use from native vegetation to agricultural fields and past

See Text S1 for a description of the methods used. Data on species geographic distribution are derived from IUCN (2017) and the scenarios of agricultural expansion from the Integrated Model to Assess the Global Environment (IMAGE, version 2.2) (IMAGE Team, 2001) (see Dobrovolski et al., 2013). Notice the spatial shift of conservation conflicts, including the abandonment of some agricultural areas by 2100 in DRC and Madagascar. This condition, however, may not imply an immediate benefit for primate species, as local populations would have been extirpated, areas would have been dramatically altered prior to abandonment, and would likely require decades to regenerate to closed-canopy, old secondary forest. See Fig. $\mathrm{S} 6$ for a model based on an optimistic scenario and on a business-as-usual scenario. 


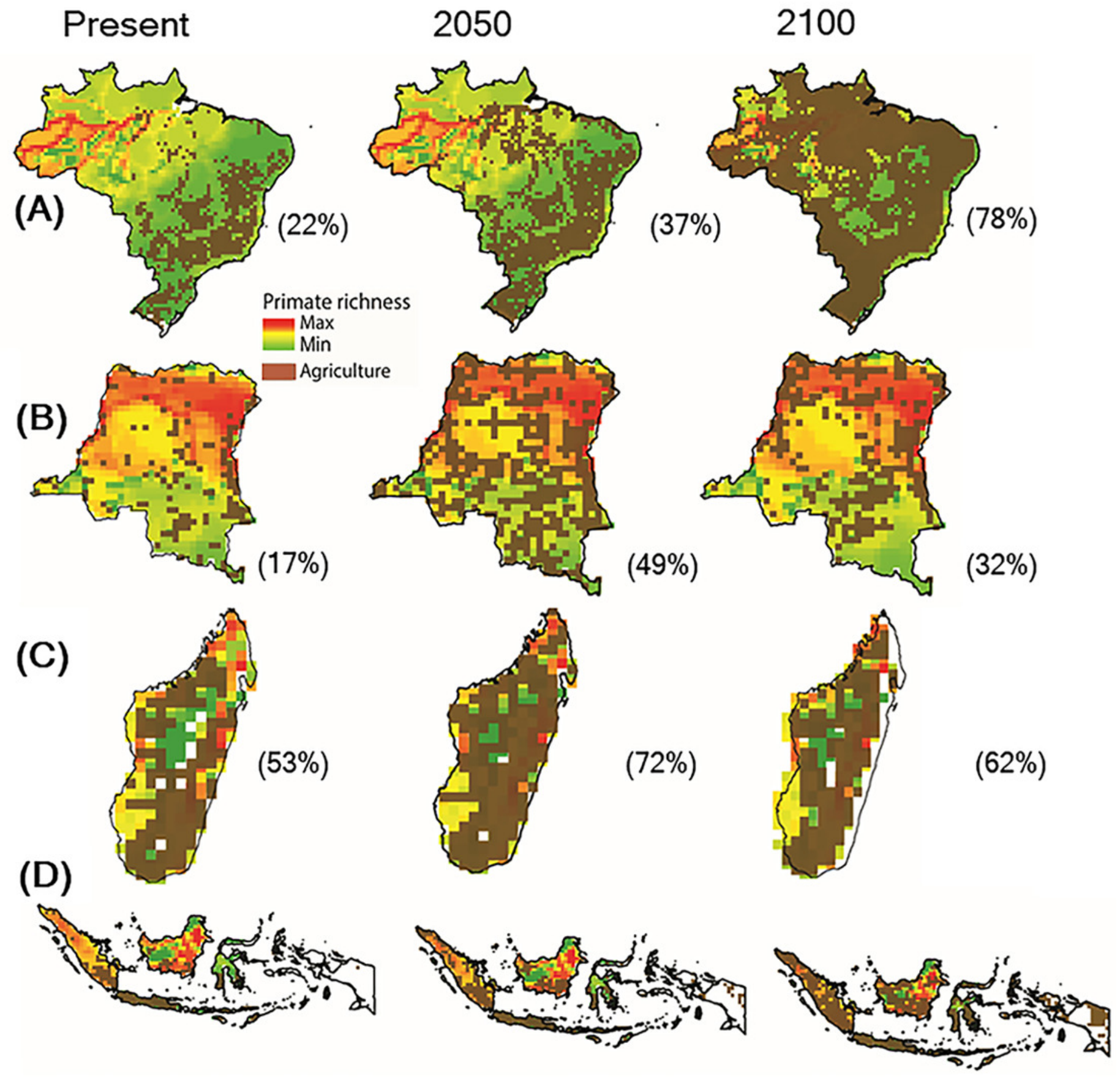




\section{Figure 4}

Photos of selected land cover changes in primate range countries, illegal primate trade, and the primate bushmeat trade.

Photo credits include the following: (A) Soybean plantation and recent deforestation of forest patches in the Cerrado Biome, Jataí, Goiás State, Brazil (Photo credit: Fabiano R. de Melo),

Pastures for cattle ranching surrounding Atlantic Forest patches inside the Cerrado Biome, Rio Verde, Goiás State, Brazil. (Photo credit: Izaltino Guimarães Jr.), (C) Indonesia, illegal logging Central Kalimantan (Photo credit: R. Butler), (D) Indonesia, deforestation (Photo credit: R. Butler), (E) Indonesia, Sunda slow loris (Nycticebus coucang), sold in Jakarta (Photo credit: A. Walmsley and Little Fireface Project), (F) DRC, smoked bonobo (Pan paniscus) meat at a rural meat market (Photo credit: J. Head).
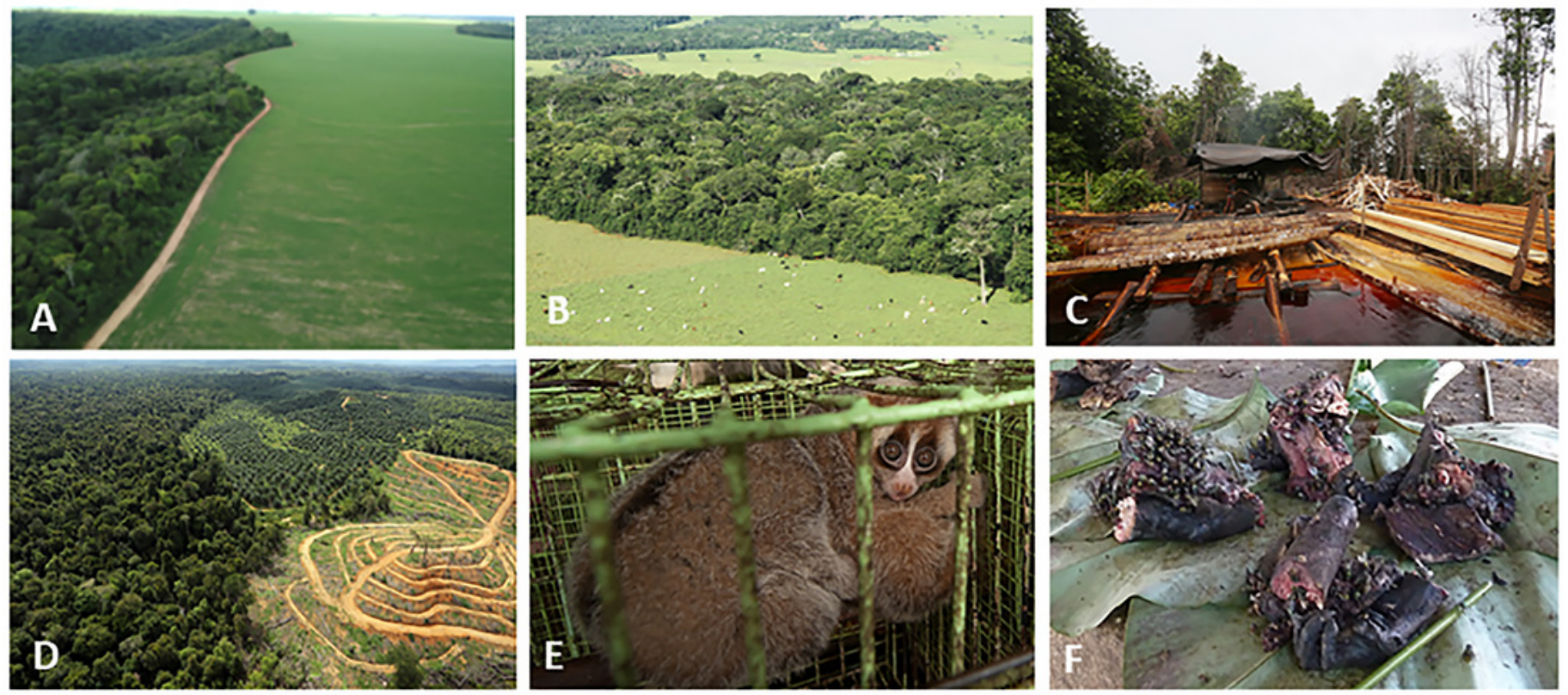
Figure 5

Total urban and rural population growth and projections for (A) Brazil, (B) DRC, (C) Madagascar, and (D) Indonesia.

Steep growth is forecasted for the next few decades with urban populations significantly increasing, while rural populations are expected to decline. Source:

http://www.fao.org/faostat/en/\#data (accessed 15 August 2017).
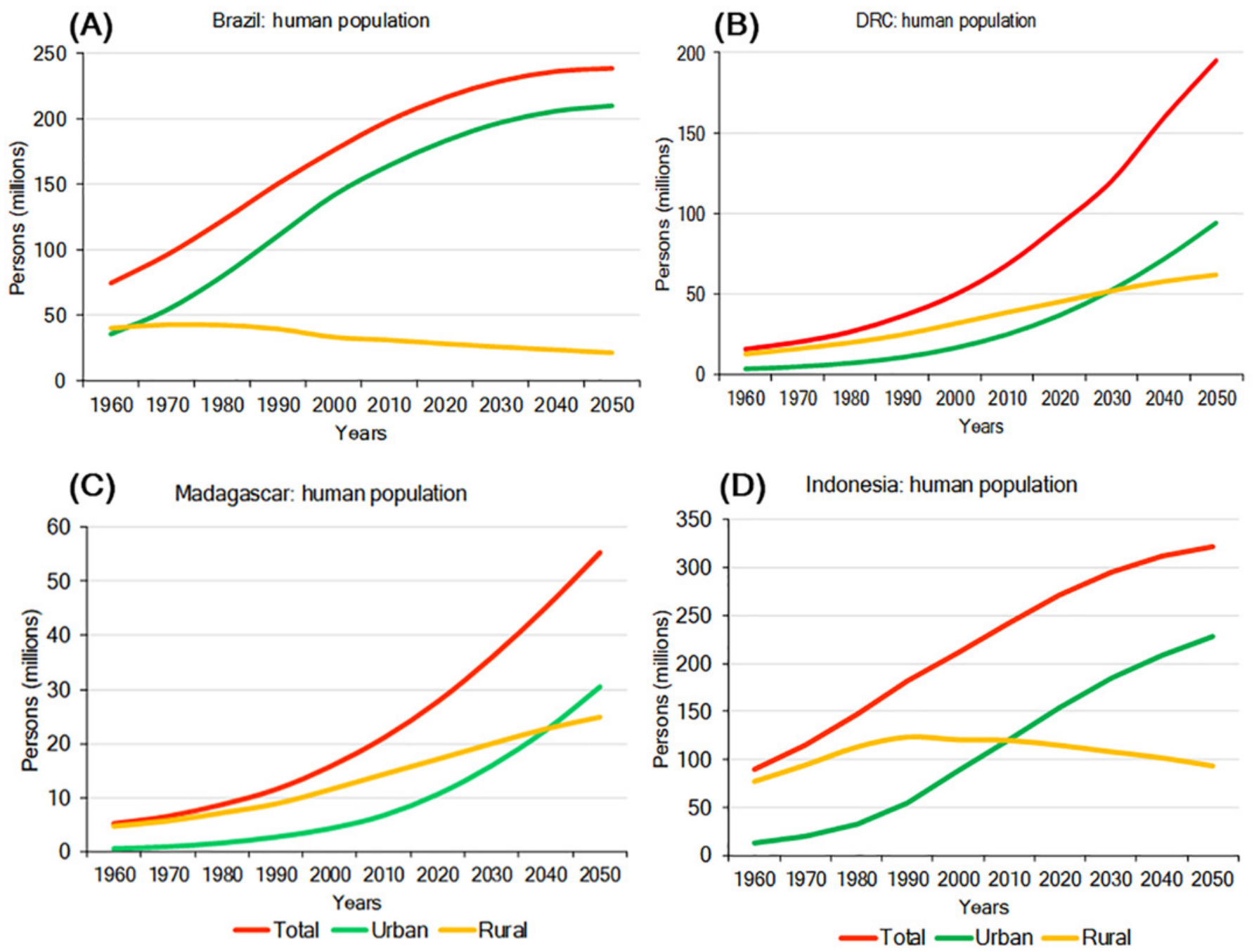
Figure 6

Gross Domestic Product per capita (GDPPC International USD) in the four countries for the period 1990 to 2015.

Included for comparison are the world's average and the average for the top 25 most developed nations. The trends for DRC and Madagascar are shown in the small line graph on the right. Available at

http://data.worldbank.org/indicator/NY.GDP.PCAP.CD? contextual=max\&locations=BR\&year $h$ igh_desc=false; http://data. worldbank.org/indicator/NY.GDP.PCAP.CD (accessed November 2017).

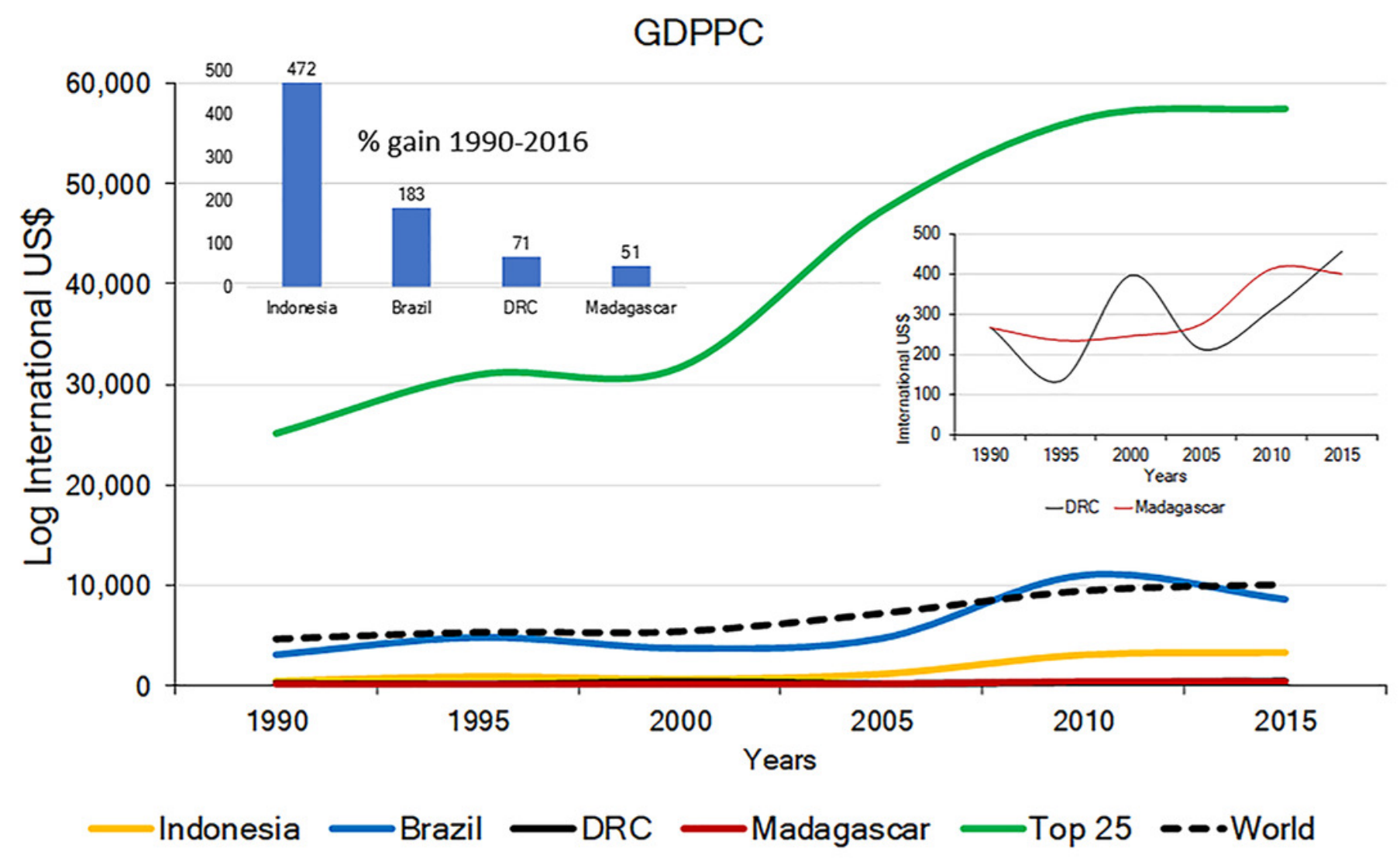




\section{Figure 7}

The 1990 to 2015 Human Development Index (HDI) in Brazil, Indonesia, Madagascar and DRC (Lowest human development $=0$; highest $=1.0$ ). Also shown is the average HDI for the world and for the top 25 most developed nations.

The number in parentheses after each country indicates their HDI world rank. The number in parenthesis after the name of each country indicates its HDI ranking compared to 188 countries. No data are available for Madagascar for 1990. Source: United Nations Development Program (http://hdr.undp.org/en/composite/trend (accessed 11 January 2018).

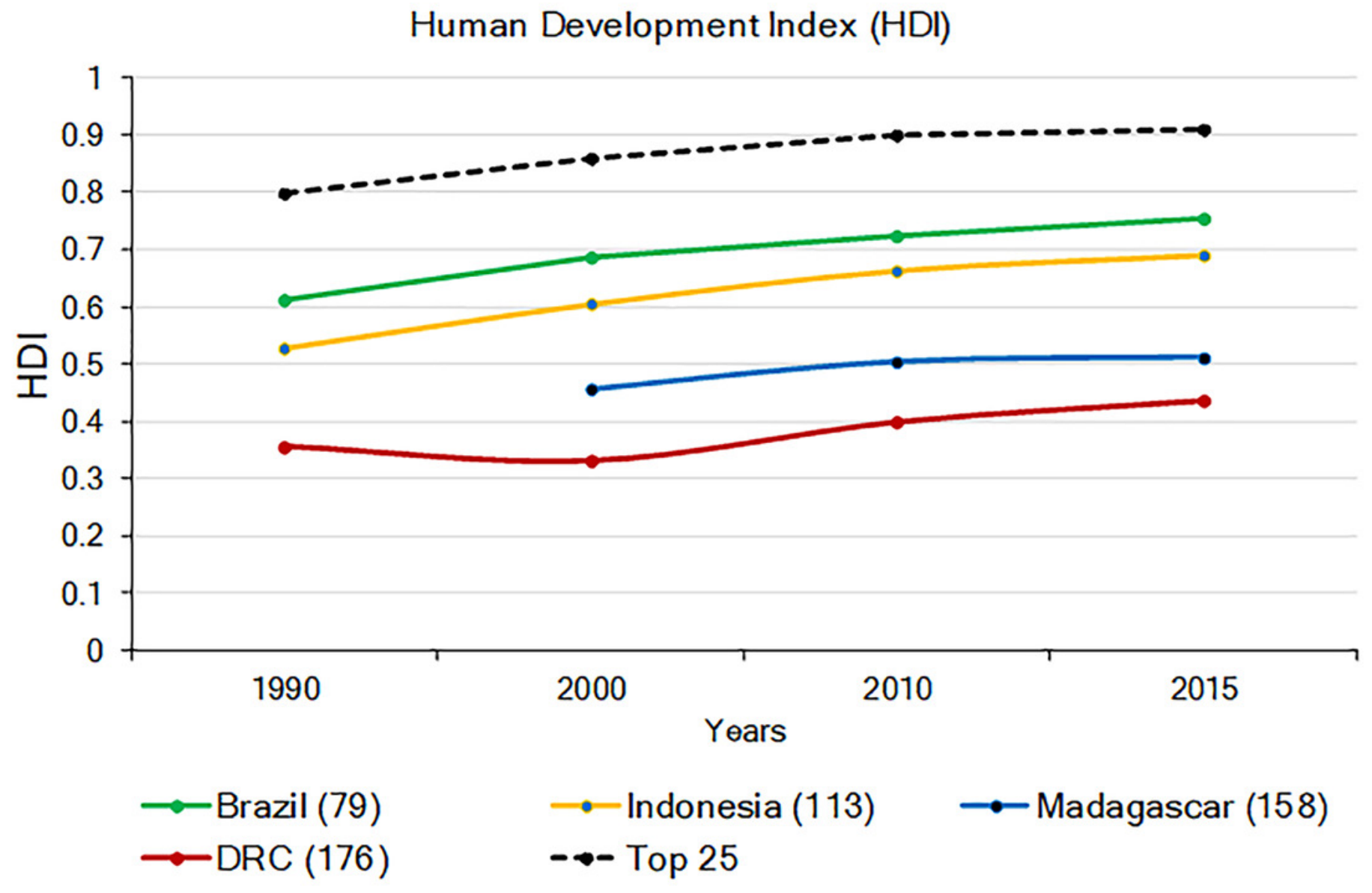




\section{Figure 8}

The graph, produced using the World Bank database, shows the percentile rank of four key World Bank governance indicators for Brazil, DRC, Madagascar, and Indonesia. Percentile rank: the percentage of countries that rate below the selected country.

Higher values indicate better governance ratings. Shown for comparison is the percentile rank for high-income OECD countries ( $n=35$; Organization for Economic Co-operation and Development). Percentile ranks have been adjusted to account for changes over time in the set of countries covered by the governance indicators. The statistically likely range of the governance indicator is shown as a thin black line. For instance, a bar of length $75 \%$ with the thin black lines extending from $60 \%$ to $85 \%$ has the following interpretation: an estimated $75 \%$ of the countries rate worse and an estimated $25 \%$ of the countries rate better than the country of choice. Source: http://info.worldbank.org/governance/wgi/index.aspx\#reports (accessed 17 November 2017). 


\begin{tabular}{|c|c|c|c|c|c|}
\hline Indicator & Country & Year & $\begin{array}{l}\text { Percentile Rank } \\
(0 \text { to } 100)\end{array}$ & & \\
\hline \multirow{5}{*}{$\begin{array}{l}\text { Political Stability and } \\
\text { Absence of } \\
\text { Violence/Terrorism }\end{array}$} & High income: OECD & 2016 & & & \\
\hline & Brazil & 2016 & $\longrightarrow$ & & \\
\hline & Congo, Dem. Rep. & 2016 & ㄹ & & \\
\hline & Indonesia & 2016 & $\longrightarrow$ & & \\
\hline & Madagascar & 2016 & $\longrightarrow$ & & \\
\hline \multirow[t]{5}{*}{ Government Effectiveness } & High income: $O E C D$ & 2016 & & & \\
\hline & Brazil & 2016 & $\longrightarrow$ & & \\
\hline & Congo, Dem. Rep. & 2016 & ב & & \\
\hline & Indonesia & 2016 & $\longrightarrow$ & & \\
\hline & Madagascar & 2016 & 2 & & \\
\hline \multirow[t]{5}{*}{ Rule of Law } & High income: OECD & 2016 & & & \\
\hline & Brozil & 2016 & $\Longrightarrow$ & & \\
\hline & Congo, Dem. Rep. & 2016 & 居 & & \\
\hline & Indonesia & 2016 & $\longrightarrow$ & & \\
\hline & Madagascar & 2016 & 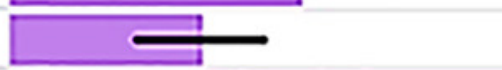 & & \\
\hline \multirow[t]{6}{*}{ Control of Corruption } & High income: OECD & 2016 & & & \\
\hline & Brazil & 2016 & $\Longrightarrow$ & & \\
\hline & Congo, Dem. Rep. & 2016 & $\Longrightarrow$ & & \\
\hline & Indonesia & 2016 & $\longrightarrow$ & & \\
\hline & Madagascar & 2016 & ב & & \\
\hline & & & 20 & 80 & 100 \\
\hline
\end{tabular}


Figure 9

Distribution of protected areas and primate distributions in (A) Brazil, (B) DRC, (C) Madagascar and (D) Indonesia.

In this model, primate species distributions are based on data from the IUCN Red List (consulted May 2017), protected areas distributions from UNEP-WCMC (2017) and forest cover from Hansen et al., 2013. Images are scaled to ca. $300 \mathrm{~m}$ of spatial resolution. We included 2190 protected areas in the Brazil dataset, 49 in DRC, 147 in Madagascar and 646 in Indonesia (Text S1).
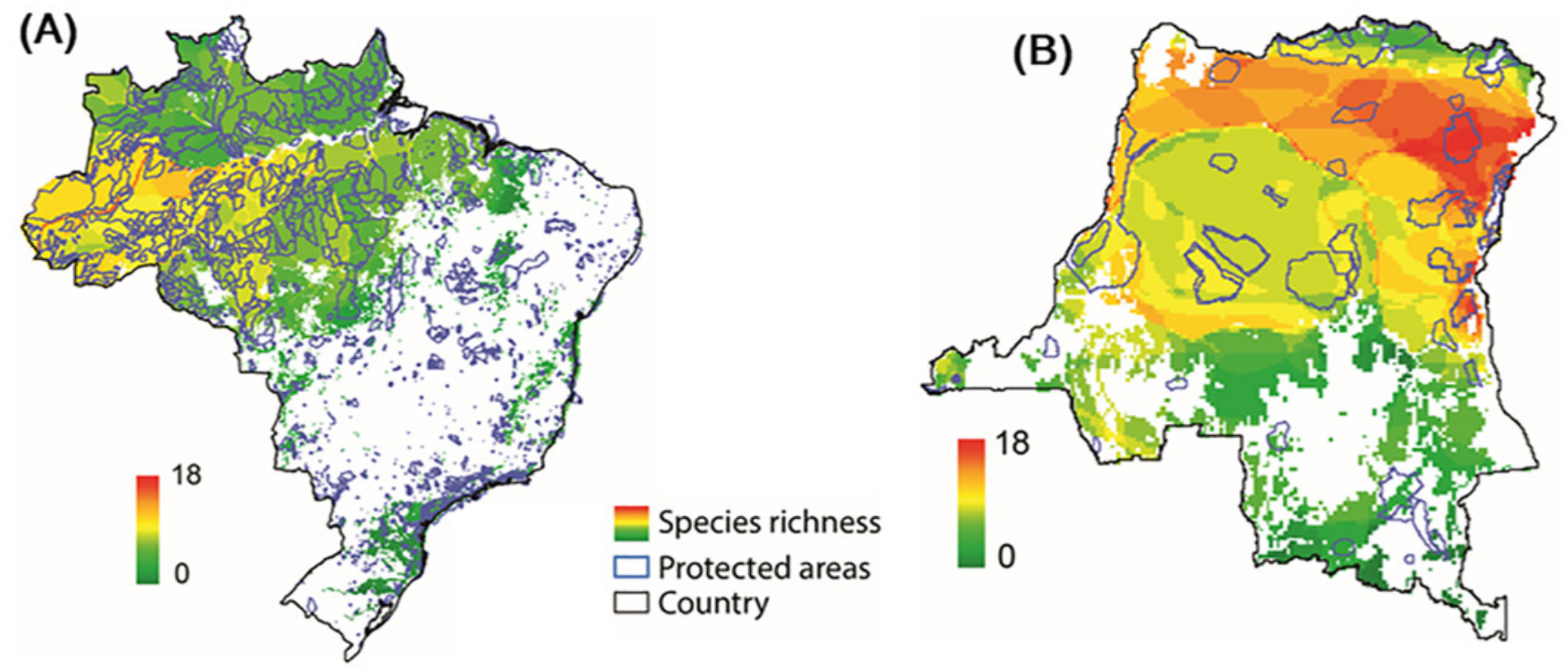

(C)

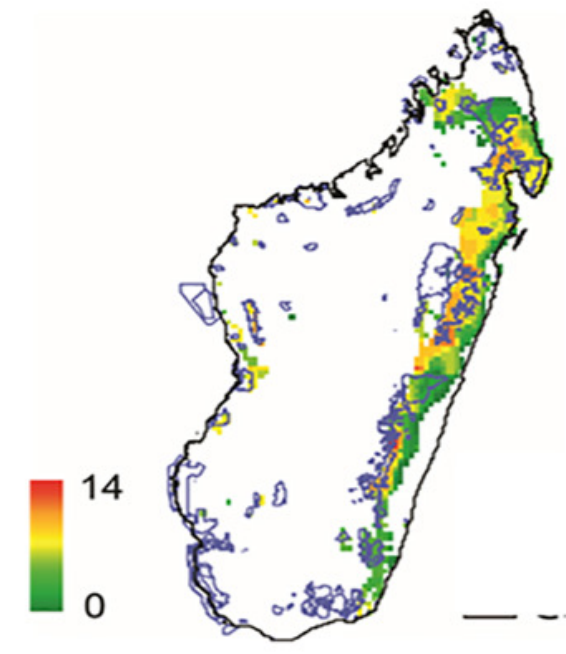

Species richness

Protected areas

Country

(D)

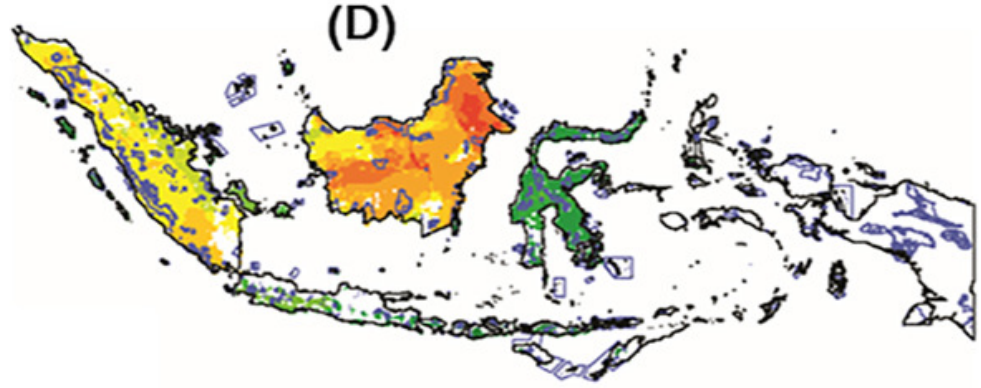




\section{Figure 10}

Photos of selected primates from each country.

Conservation status and photo credits include the following: A) DRC, Grauer's gorilla (Gorilla beringei graueri), Critically Endangered, (Photo credit: J. Martin), B) Madagascar, Sahafary sportive lemur ( Lepilemur septentrionalis) Critically Endangered (Photo credit: R. A. Mittermeier), C) Indonesia, Javan slow loris (Nycticebus javanicus), Critically Endangered (Photo Credit: Andrew Walmsley/Little Fireface Project), D) Brazil, northern muriqui ( Brachyteles hypoxanthus ), Critically Endangered (Photo credit: Raphaella Coutinho), E) Brazil, pygmy marmoset (Cebuella pygmaea), Vulnerable, (Photo credit: Pablo Yépez), F) Sumatran orangutan (Pongo abelii), Critically Endangered (Photo Credit: Perry van Duijnhoven).
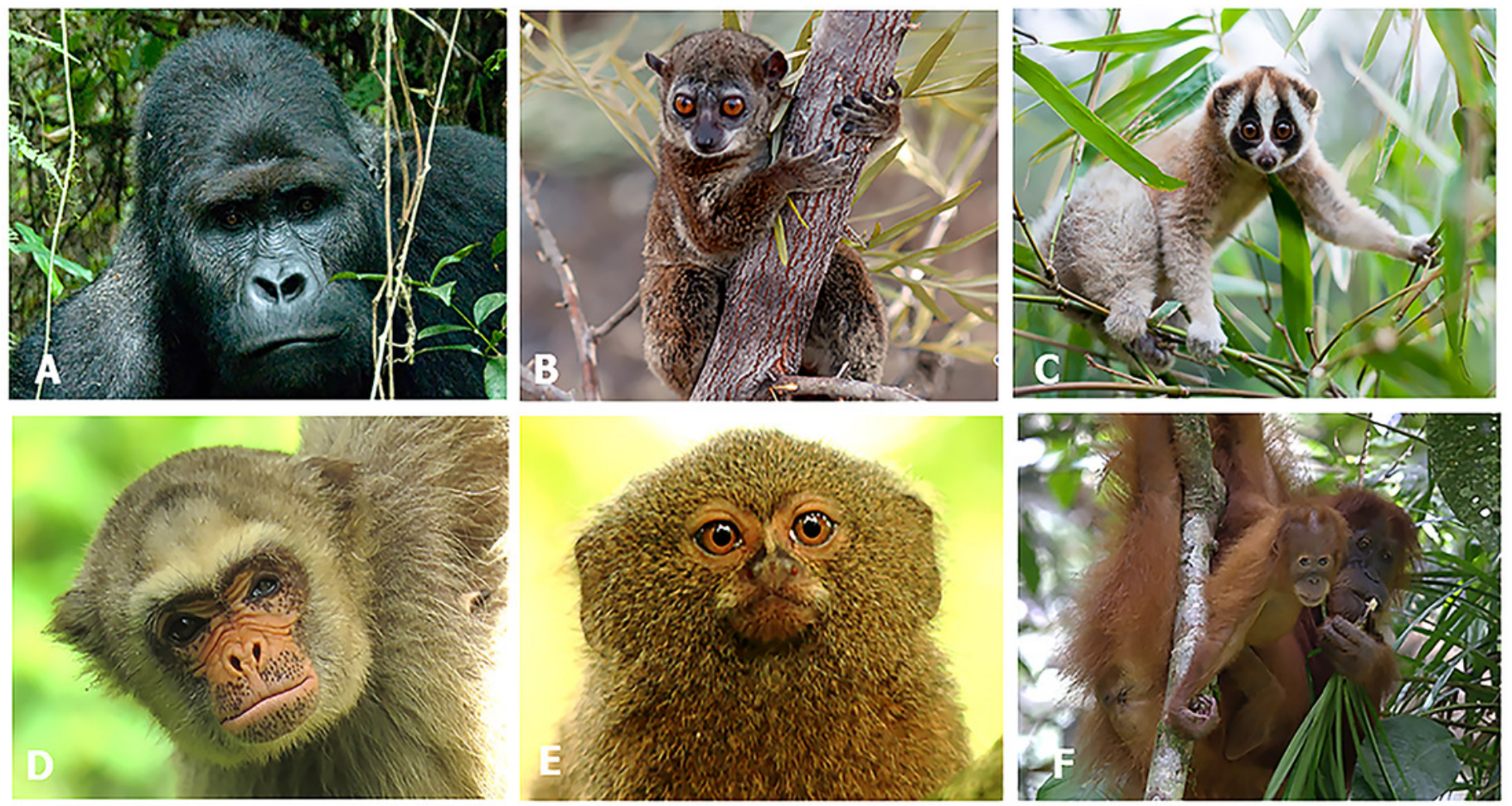


\section{Figure 11}

Diagram summarizing key environmental challenges common to Brazil, DRC, Madagascar, and Indonesia that affect conservation of their primate fauna.

The relative importance of some pressures and population aspects vary from country to country. For example, hunting in DRC is a large-scale pressure because the local human population has little or no access to domestic meat. Because of their large size and low population density relative to the size of the country, Brazil and DRC are in a better position to anticipate the direction of these pressures and prevent primate declines and extirpation. However, in contrast to Brazil, DRC is particularly poor, its human population is rapidly growing, and human development is very low, whereas civil unrest is predominant and corruption and weak governance are an ever-present condition. Madagascar differs from these two countries, and from Indonesia in having a very small percentage of its original forest left. A rapidly expanding human population and high levels of poverty and weak governance are predominant. Indonesia is a developing country with a large human population that has embarked on a policy of rapidly replacing its forests with commercial plantations and expanding industrial logging at the expense of biodiversity. 


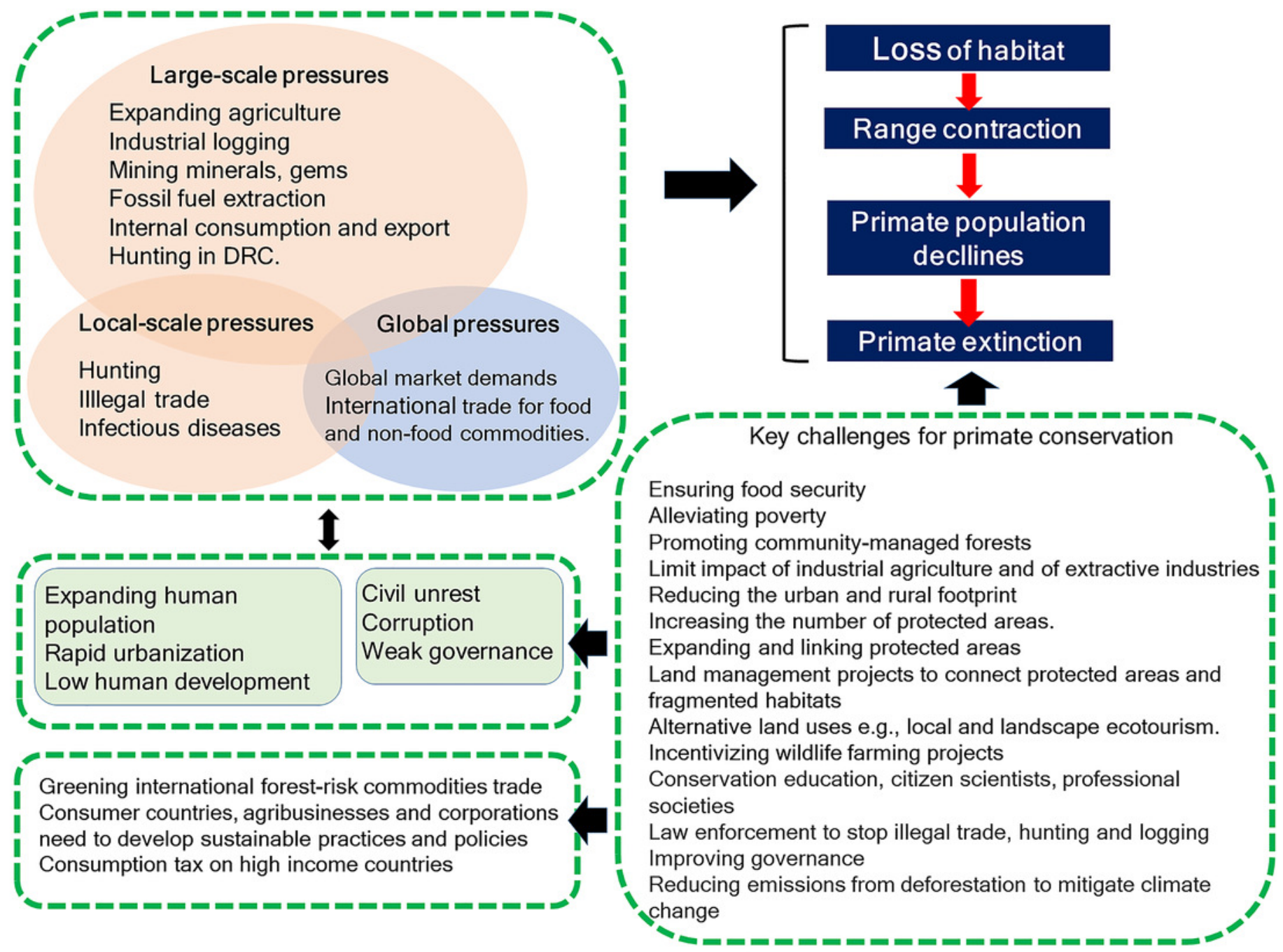

